CARLOS FELIPE TASSO FILIETAZ

PADRÕES DE ESPECIFICIDADE E EXPRESSÃO DAS LIPASES DIGESTIVAS DURANTE O DESENVOLVIMENTO E O PROCESSO INFECCIOSO NO MOSQUITO AEDES AEGYPTI

Tese apresentada ao Programa de PósGraduação Interunidades em Biotecnologia USP/Instituto Butantan/IPT, para obtenção do Título de Doutor em Biotecnologia. 


\section{PADRÕES DE ESPECIFICIDADE E EXPRESSÃO DAS LIPASES DIGESTIVAS DURANTE O DESENVOLVIMENTO E O PROCESSO INFECCIOSO NO MOSQUITO AEDES AEGYPTI}

Tese apresentada ao Programa de PósGraduação Interunidades em Biotecnologia USP/Instituto Butantan/IPT, para obtenção do Título de Doutor em Biotecnologia.

Área de concentração: Biotecnologia

Orientadora: Prof $^{\mathrm{a}}$. Dr ${ }^{\mathrm{a}}$. Adriana Rios Lopes Rocha

Versão corrigida. A versão original eletrônica, encontra-se disponível tanto na Biblioteca do ICB quanto na Biblioteca Digital de Teses e Dissertações da USP (BDTD). 


\section{DADOS DE CATALOGAÇÃO NA PUBLICAĈ̃̃O (CIP)}

Serviço de Biblioteca e Informação Biomédica do

Instituto de Ciências Biomédicas da Universidade de São Paulo

Ficha Catalográfica elaborada pelo(a) autor(a)

Filietaz, Carlos Felipe Tasso.

Padrões de especificidade e expressão das lipases digestivas durante o desenvolvimento e o processo infeccioso no mosquito Aedes aegypti. / Carlos Felipe Tasso Filietaz; orientadora Adriana Rios Lopes Rocha.-- São Paulo, 2016.

$135 \mathrm{p}$.

Tese (Doutorado) - Universidade de São Paulo. Instituto de Ciências Biomédicas.

1. Aedes aegypti. 2. Lipase. 3. Sistema Digestório. 4. Enzimologia.

5. Digestão. I. Lopes, Adriana Rios, orientador . II. Título. 


\section{UNIVERSIDADE DE SÃO PAULO \\ Programa de Pós-Graduação Interunidades em Biotecnologia}

Universidade de São Paulo, Instituto Butantan, Instituto de Pesquisas Tecnológicas

Candidato(a): $\quad$ Carlos Felipe Tasso Filietaz.

Título da Tese: Padrões de especificidade e expressão das lipases digestivas durante 0 desenvolvimento e o processo infeccioso no mosquito Aedes aegypti.

Orientador(a): $\quad \quad \operatorname{Prof}^{\mathrm{a}}$. Dr ${ }^{\mathrm{a}}$. Adriana Rios Lopes Rocha.

A Comissão Julgadora dos trabalhos de Defesa da Tese de Doutorado, em sessão pública realizada a .................., considerou
( ) Aprovado(a)
( ) Reprovado(a)

\begin{tabular}{|c|c|}
\hline Examinador(a): & $\begin{array}{l}\text { Assinatura: } \\
\text { Nome: ....... } \\
\text { Instituição: }\end{array}$ \\
\hline Examinador(a): & $\begin{array}{l}\text { Assinatura: } \\
\text { Nome: ....... } \\
\text { Instituição: }\end{array}$ \\
\hline Examinador(a): & $\begin{array}{l}\text { Assinatura: } \\
\text { Nome: ........ } \\
\text { Instituição: }\end{array}$ \\
\hline Examinador(a): & $\begin{array}{l}\text { Assinatura: } \\
\text { Nome: ........ } \\
\text { Instituição: }\end{array}$ \\
\hline Presidente: & $\begin{array}{l}\text { Assinatura: } \\
\text { Nome: ....... } \\
\text { Instituição: }\end{array}$ \\
\hline
\end{tabular}




\section{CERTIFICADO DE ISENÇÃO}

Certificamos que o Protocolo CEP-ICB N ${ }^{\circ}$ 403/10 referente ao projeto intitulado: "Caracterização da digestão de lipídeos em vetores bematófagos e o papel fisiológico das lípases” sob a responsabilidade de Carlos Felipe Tasso Filietaz, foi analisado na presente data pela CEUA COMISSÃO DE ÉTICA NO USO DE ANIMAIS e pela CEPSH- COMISSÃO DE ÉTICA EM PESQUisa COM SERES humanos, tendo sido deliberado que o referido projeto não envolve manipulação animal ou humana que justifique uma aprovação quanto aos princípios éticos exigidos por ambas as Comissões.

São Paulo, 21 de junho de 2010.
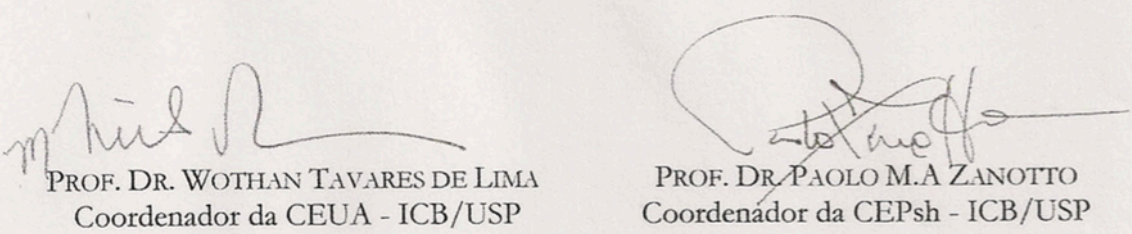
A meus pais, Carlos Alberto Filietaz e Gilseres Tasso Filietaz, por me incentivarem a crescer, pelo suporte emocional e amor incondicional. 


\section{AGRADECIMENTOS}

Primeiramente e acima de tudo quero agradecer a Deus. Pelo sustento diário, por me permitir caminhar na sua presença, me fazer ouvir Sua voz e porque nenhuma das promessas que Ele me fez deixaram de se cumprir até hoje.

As palavras aqui utilizadas são pequenas e talvez imperfeitas para agradecer cada um que será citado. Todos são muito especiais e contribuiram, em menor ou maior grau para a conclusão desse trabalho, desde já meu muito obrigado.

Aos meus queridos pais Carlos Alberto Filietaz e Gilseres Tasso Filietaz pelo amor e cuidado. Por estarem próximos de mim durante todo esse percurso, pelas orações e conselhos, por me incentivarem a nunca me conformar com o homem que sou hoje e sim a buscar minha melhor versão a cada dia. Também, pelo exemplo de perseverança e garra que tenho buscado alcançar.

Ao exemplo de vida de meus avós Levi Filietaz, Iria de Almeida Filietaz, Dorival Tasso e Jacira Maria Tasso. É um privilégio poder chamar vocês de meus avós, sinto muito orgulho de tudo que vocês são e alcançaram, são sem sombra de dúvida um grande exemplo de vida.

Aos meus tios, tias e primos por sempre estarem presentes, por torcerem e desejarem o meu crescimento e sucesso.

Agradeço a minha irmã Carla Francini Tasso Filietaz, pelo carinho que tem por mim, você é o presente que eu pedi a Deus. Por ser um exemplo de conduta, coragem e dedicação.

A minha orientadora Dra. Adriana Rios Lopes por buscar sempre a excelência em tudo que faz, inclusive na orientação de seus alunos. Só posso dizer que foi uma honra poder compartilhar cada dia desses muitos anos de trabalho, poder observar o crescimento e o estabelecimento dessa linha de pesquisa e desse laboratório. Obrigado por ser sempre criteriosa, por sempre buscar tirar o melhor de cada um de nós e pela paciência durante esse período. Foi um privilégio poder ser orientado no mestrado e doutorado por você, acredito que o seu exemplo de amor e dedicação ao trabalho fizeram de mim um melhor profissional, sempre será um exemplo a ser seguido. Desejo muito sucesso em tudo que fizer, que Deus abençoe muito sua vida. 
Agradeço a minha namorada Carla Miron Bastelli, pelo amor, companheirismo e fidelidade em toda essa caminhada. Nesses 8 anos de namoro nunca deixou de me incentivar, mas esteve ao meu lado em todos os momentos. Nunca olhou e apontou as minhas falhas, mas consegue extrair de mim o melhor e me faz querer ser alguém ainda melhor a cada dia. Obrigado pelos risos, pelos choros, pelas orações, pelo carinho, por torcer por mim, por lutar por nós e por ser tão doce, delicada, mas tão forte ao mesmo tempo. Caminhar com você tem sido uma experiência única me sinto muito feliz por ter o privilégio de sentir seu amor.

Agradeço a meus futuros sogro e sogra Carlos Roberto Bastelli e Marlene Aparecida Miron Bastelli, e a avó Maria Esterina Balaminute. Por terem criado essa pessoa tão especial que é a Carla e por terem me recebido com tanto carinho nessa família.

Aos meus colegas de laboratório, Felipe Jun Fuzita, Maria Cicera Pereira da Silva, Natalia Nappi Perella, Mariana Tonelloto e Rodrigo Moreti da Silva. Todos os momentos vividos no laboratório foram muito enriquecedores, aprendi muito com vocês, todas as discussões trouxeram muito crescimento pessoal, científico e foram muito relevantes para a conclusão desse trabalho. Aos alunos que passaram pelo laboratório, que também contribuíram de forma especial, Angela Mazzaroppi, Pedro Monteiro e Aline Gonsalves Gomes Serrão. Agradeço também ao Douglas Mariano, pelo auxílio com o equipamento e análises de espectrometria de massa e pela amizade desenvolvida nesse período.

A todos os pesquisadores do laboratório de Bioquímica e Biofísica do Instituto Butantan. Em especial Dra. Ana Marisa Chudzinski Tavassi, Dra. Marilene Demasi, Dr. Daniel Carvalho Pimenta, Dra. Ana Olívia de Souza, Dra. Isabel Correia, Dra. Janice Onuki e Dr. Ivo Lebrun, que colaboraram de diversas formas para a conclusão desse trabalho, desde o compartilhamento de ideias, discussões científicas e metodológicas ao uso de equipamentos e material laboratorial.

Ao Dr. Walter Terra e Dra. Clélia Ferreira do departamento de Bioquímica da Universidade de São Paulo, por permitirem a utilização de equipamentos reagentes e por toda a contribuição científica e sugestões dadas em reuniões. Em especial a equipe do laboratório, os técnicos Chris, Gillearde e Nilde; e aos pós graduandos, André, Ticiane, Walciane e Gabriel, pelo suporte na utilização de equipamentos e pelas conversas que ajudaram a resolver muitos problemas. 
A Dra. Margareth de Lara Capurro-Guimarães, professora do laboratório de mosquitos geneticamente modificados do Instituto de Ciências Biomédicas USP. Por ceder espaço, mosquitos, estrutura para as infecções e equipamentos para as análises de qPCR. Em especial ao Dr. André Luis da Costa da Silva, pela disponibilidade e atenção em todos os momentos, por me ensinar a realizar e analisar experimentos utilizando a metodologia de qPCR. A Msc. Rafaella Sayuri loshino, por toda ajuda com o manejo dos mosquitos, alimentação, infecções, planejamento dos horários, pelas conversas e amizade.

A Dra. Andrea Balan do departamento de Microbiologia da USP. Por ceder os vetores pOP que foram testados para a expressão das lipases.

A todos os técnicos do laboratório Bioquímica e Biofísica do Instituto Butantan. A Patrícia e Antônia pelos cafés e brincadeiras, Bia, Priscila, Marcia, João, Júlio, Rafael e a secretária Caroline pelos momentos de descontração diários na copa e auxílios gerais com equipamentos. Em especial a Silvana por toda a ajuda no preparo de soluções, preparação de gel, autoclavagem e lavagem de material. Essas pequenas coisas ajudaram muito a otimizar o tempo de trabalho e a aumentar a quantidade de experimentos. Aos técnicos Adrian Hand e Admilson, pelo auxílio na utilização de equipamentos e acessórios.

As agencias financiadoras, CNPq (número do processo: 140393/2013-7) e a FAPESP pela manutenção do laboratório. 


\section{RESUMO}

Filietaz, C. F. T. Padrões de especificidade e expressão das lipases digestivas durante $o$ desenvolvimento e o processo infeccioso no mosquito Aedes aegypti. 2016. 135 f. Tese (Doutorado em Biotecnologia) - Instituto de Ciências Biomédicas, Universidade de São Paulo, São Paulo, 2016.

O mosquito Aedes aegypti é vetor de doenças como dengue, chinkungunya e zika. A infecção do mosquito ocorre através do repasto sanguíneo. A espécie lipídica mais abundante no sangue são os triacilgliceróis (TAGs). Na digestão, os TAGs são hidrolisados pelas lipases em glicerol e ácidos graxos, permitindo a sua absorção. Pouco se sabe sobre a digestão de lipídeos em mosquitos. Dados bioquímicos prévios indicavam a presença de duas lipases, uma na fase larval e outra na adulta. Esse estudo teve como objetivo identificar as lipases digestivas em larvas e fêmeas adultas de $A e$. aegypti, analisar suas estruturas, padrão de expressão e regulação de expressão durante a infecção com vírus dengue (DENV2) e com Plasmodium galinaceum. As análises in silico das lipases foram realizadas com as sequências do genoma do mosquito. Das 8 lipases identificadas, 2 tiveram a expressão confirmada por qPCR no sistema digestório, a lipase L-Aa7051 (larval) e a L-Aa7055 (fêmea adulta). O nível de expressão de L-Aa7051 é 160 vezes maior que L-Aa7055, demonstrando que as lipases do mosquito apresentam expressão diferencial ligada a fase do desenvolvimento. A expressão de L-Aa7055 em fêmeas adultas é independente do tipo de alimento, dado que não houve variação de expressão em fêmeas alimentadas com sangue ou sacarose. A análise de alinhamento de sequencias mostrou que estas lipases pertencem às lipases neutras. Entretanto, LAa7051 e L-Aa7055 não apresentam a região de ligação a colipase e apresentam diminuição dos domínios relacionados à especificidade ao substrato (alça $\beta 9 \mathrm{e}$ domínio tampa). Estas alterações estruturais estão relacionadas a lipases que atuam sobre substratos distintos e preferencialmente substratos de cadeia curta, o que também foi confirmado para as lipases de mosquito. A L-Aa7055 recombinante foi obtida em sistema de expressão pET-SUMO, sendo expressa em Escherichia coli em corpos de inclusão, os quais foram renaturados. A enzima recombinante apresentou $\mathrm{Km}$ de $63 \mu \mathrm{M} \pm 6 \mu \mathrm{M}$ utilizando-se oleato como substrato, semelhante ao obtido para a forma nativa da enzima presente no mosquito adulto, indicando serem a mesma enzima. O efeito da infecção na expressão da L-Aa7055 foi verificado por qPCR. Na infecção por DENV2 não foi observada variação nos níveis de expressão no segundo ciclo gonotrófico. Na infecção por $P$. gallinaceum a expressão é aumentada 15 horas após a alimentação no $1^{\circ}$ ciclo gonotrófico e é diminuída 18 horas após a alimentação no $2^{\circ}$ ciclo gonotrófico. Portanto, demonstramos que a 
expressão de pelo menos uma lipase digestiva pode ser alterada durante o processo infeccioso e que esta resposta é distinta perante as diferentes infecções. Outros estudos da interação parasita-hospedeiro e a expressão diferencial de enzimas digestivas poderão esclarecer todos os processos moleculares envolvidos nessa interação auxiliando no desenho de estratégias de controle para diminuição da transmissão destes parasitas.

Palavras-chave: Aedes aegypti. Lipase. Sistema digestório. Enzimas digestivas. 
Filietaz, C. F. T. Patterns of specificity and digestive lipases expression during the infectious process and development on the mosquito Aedes aegypti. 2016. 135 p. Thesis (Ph. D. Thesis in Biotechnology) - Instituto de Ciências Biomédicas, Universidade de São Paulo, São Paulo, 2016.

Ph. D. Thesis

The mosquito Aedes aegypti is the vector of several diseases such as, dengue, chikungunya and zika. The mosquito infection occurs through blood feeding on an infected host. Triacylglycerol (TAGs) is the lipidic species more frequent in blood. During digestion, the TAGs are hydrolyzed by lipases in glycerol and fat acids, allowing nutrient absorption. Lipid digestion by mosquitos is poorly understood. Biochemical data obtained previously indicated that lipases present in larva and adult females from Ae. aegypti are different. The present study had the aim to identify the digestive lipases in larva and adult females, analyze them regarding their structures, expression and also their expression during the infectious process due to Dengue virus (DENV2) or Plasmodium galinaceum. In silico analysis from this mosquito genome allowed the identification of 8 candidates to digestive lipases. Two of them were identified as real digestive lipases by qPCR. The lipase LAa7051 is expressed in larva and L-Aa7055 is expressed in adult females. L-Aa7051 presents an expression level 160 times higher than L-Aa7055 indicating the importance of lipid digestion during larval development. The amplification profile during feeding has evinced that the mRNA synthesis of L-Aa7055 is independent from diet, since blood or sucrose feeding mosquitos present the same expression levels. Alignment analysis showed that these lipases belong to the neutral lipase family. However, LAa7051 and L-Aa7055 do not present the colipase binding domain, and they present amino acids alterations in domains related to substrate specificity ( $\beta 9$ loop and lid). LAa7055 was expressed in Escherichia coli using pET-SUMO expression system. The protein was present in inclusion bodies and it was renaturated. The recombinant LAa7055 presents a $\mathrm{Km}$ of $63 \mu \mathrm{M} \pm 6 \mu \mathrm{M}$ similar to the value obtained to lipase activity present in the female midgut. The effect of the infection by DENV2 and Plasmodium galinaceum after the first and second gonotrophic cycle in the expression of L-Aa7055 was followed by qPCR. There was no alteration in this lipase expression during virus infection. However, increased expression of L-Aa7055 was 
observed after 15 hours in the first gonotrophic cycle and downregulation after 18 hours of feeding on the second gonotrophic cycle of this gene. These results indicate that at least one lipase is affected in the infeccious process and distinctly regulated by different parasites. Other studies regarding host-parasite interaction and the differencial expression of digestive enzymes will be necessary to elucidate all molecular events related to infection and to allow the development of control strategies.

Keywords: Aedes aegypti. Lipase. Digestive system. Digestive enzymes. 


\section{LISTA DE ABREVIATURAS}

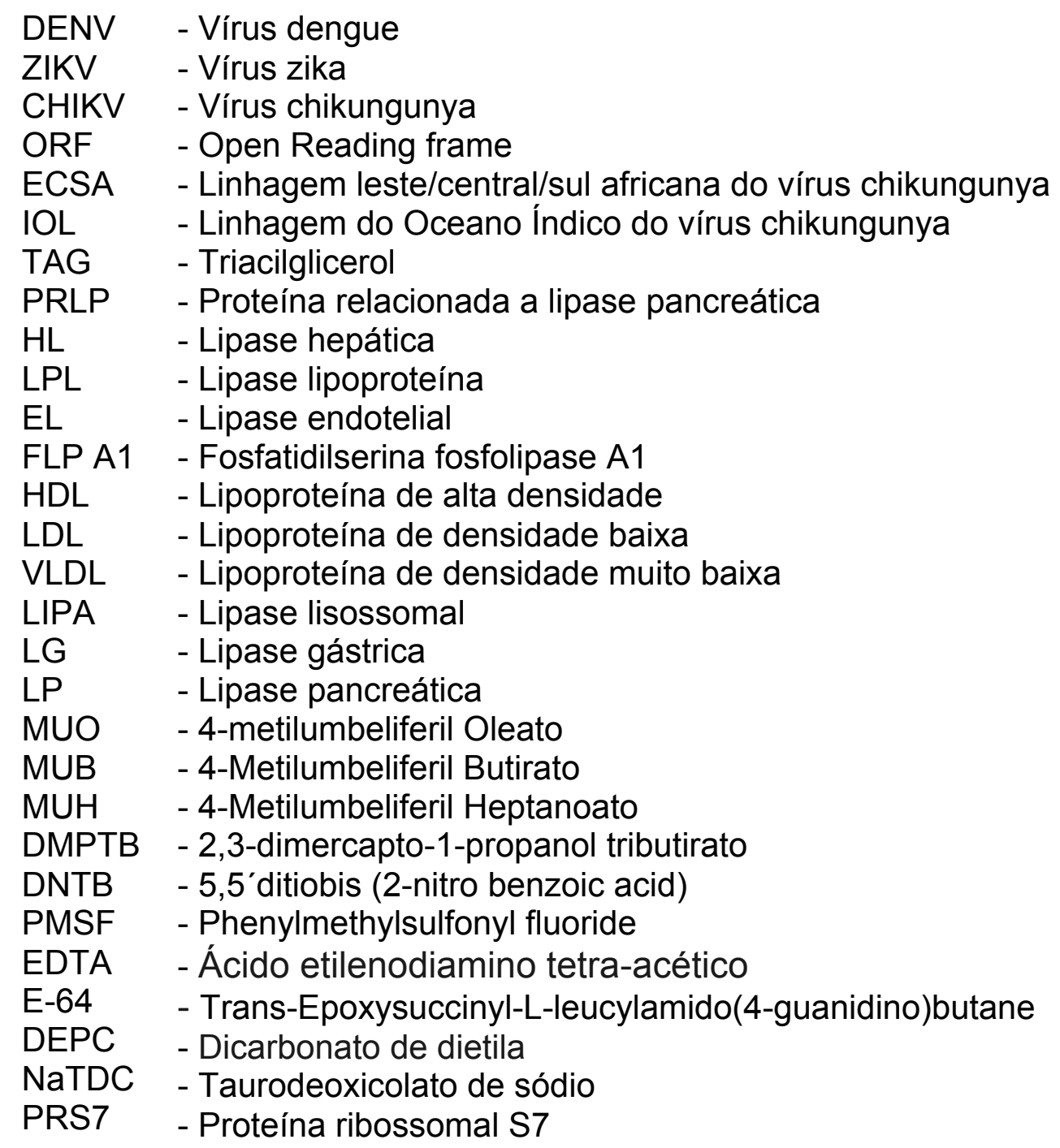




\section{LISTA DE FIGURAS}

Figura 1 - Representação do dímero de proteína E/M de DENV-2 .

Figura 2 - Ciclo do desenvolvimento do Plasmodium no hospedeiro vertebrado e invertebrado 32

Figura 3 - Ciclo de vida do mosquito Aedes aegypti 35

Figura 4 - Representação esquemática do sistema digestório de larvas de $A e$. aegypti 37

Figura 5 - Representação esquemática do sistema digestório de adultos de Ae.aegypti 38

Figura 6 - Estrutura do complexo lipase pancreática humana e colipase em duas diferentes conformações

Figura 7 - Estrutura da lipase gástrica humana 45

Figura 8 - Critério de seleção para as sequências anotadas como lipase provenientes do genoma do mosquito Ae. aegypti

Figura 9 - RT-PCR semi-quantitativo para identificação das lipases digestivas em Aedes aegypti 54

Figura 10 - Substratos derivados de 4-metilumbeliferona, utilizados para a medida da atividade enzimática de lipase 59

Figura 11 - Verificação da infecção por Plasmodium gallinaceum, pela presença de oocistos no epitélio intestinal 65

Figura 12 - Identificação dos momentos utilizados para análise por GPCR na infecção por Plasmodium gallinaceum

Figura 13 - Esquema da infecção do mosquito Aedes aegypti 69

Figura 14 - Esquema da seleção das sequências de lipase usadas para alinhamento e construção da árvore filogenética 79

Figura 15 - Alinhamento em ClustalW2 das lipases L-Aa7055 e L-Aa7051, de Ae. aegypti, com lipases digestivas descritas $81-82$

Figura 16 - Análise filogenética molecular utilizando o método de máxima verossimilhança $84-85$

Figura 17 - Destaque dos subgrupos 1 (SG-P1) e 2 (SG-P2) das lipases neutras 86 
Figura 18 - Destaque do subgrupo 3 das lipases neutras ............................. 86

Figura 19 - Destaque do subgrupo 3 das lipases neutras ........................... 87

Figura 20 - Destaque do subgrupo 1 das lipases gástricas ............................ 89

Figura 21 - Destaque dos subgrupos 2 (SG-G2) e 3 (SG-G3) das lipases gástricas

Figura 22 - Análise dos dados obtidos em qPCR para a expressão da lipase LAa7055 em adultos e larvas de Ae. aegypti

Figura 23 - Análise dos dados obtidos em qPCR para a expressão da lipase LAa7051 em larvas e adultos de Ae. aegypti

Figura 24 - Amplificação do gene de lipase AAEL705500 por RT-PCR no intestino médio de fêmeas adultas do mosquito Ae. aegypti em diferentes condições de alimentação

Figura 25 - Análise dos dados obtidos em qPCR para a expressão da lipase LAa7055 em Ae. aegypti adulto na infecção por Plasmodium gallinaceum 95

Figura 26 - Análise dos dados obtidos em qPCR para a expressão da lipase LAa7055 no intestino médio de Ae. aegypti adulto na infecção por DENV2 96

Figura 27 - Perfil de expressão proteica das lipases L-Aa7055 e L-Aa7051, sistema pAE, em células BL21(DE3) e Origami(DE3) $97-98$

Figura 28 - Perfil de expressão proteica das lipases L-Aa7055 e L-Aa7051, sistema pAE, em células BL21 Star (DE3) pLysS 98

Figura 29 - Perfil de expressão proteica da lipase L-Aa7055, sistema pOP, em célula BL21 (DE3) .......................................................... 99

Figura 30 - PCR de clonagem do vetor pET-L7055, em sistema pET-SUMO ... 100

Figura 31 - Perfil de expressão proteica de L-Aa7055/Sum, em células E. colli BL21(DE3), sistema pET-SUMO .................................... 100

Figura 32 - Purificação da lipase recombinante L-Aa7055/Sum em coluna de níquel 101

Figura 33 - Identificação dos peptídeos obtidos pela digestão da lipase recombinante L-Aa7055 em análise por espectrometria de massa (LCMS) 102 
Figura 34 - Efeito da concentração do substrato MU-Oleato $(\mu \mathrm{M})$ sobre a atividade da lipase recombinante de Ae. aegypti L-Aa7055 103 


\section{LISTA DE TABELAS}

Tabela 1 - Lipases digestivas caracterizadas bioquimicamente em diferentes

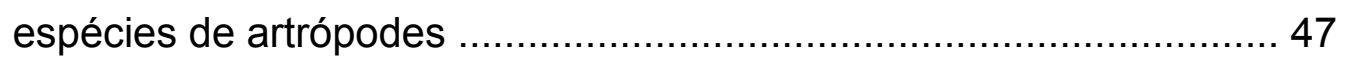

Tabela 2 - Lipases digestivas detectadas e isoladas em diferentes espécies de

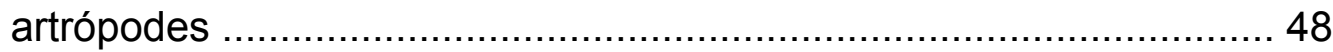




\section{SUMÁRIO}

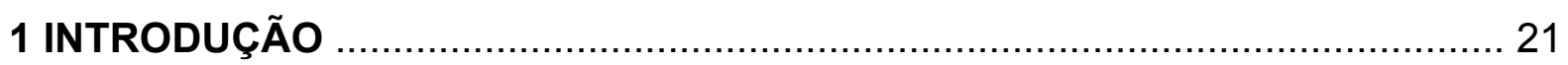

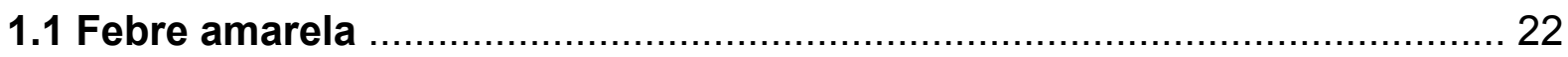

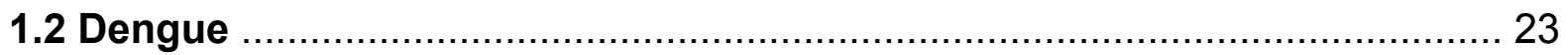

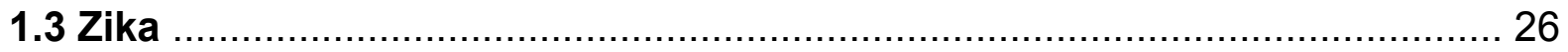

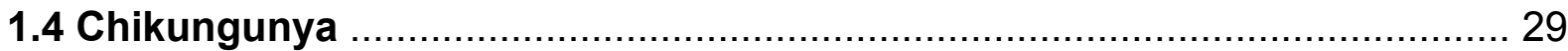

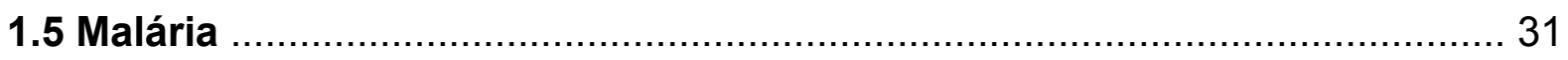

1.5 .1 O ciclo de vida do Plasmodium $s p$ no mosquito ............................................ 32

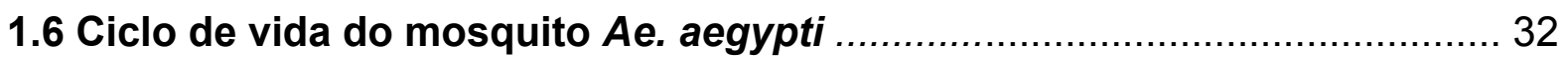

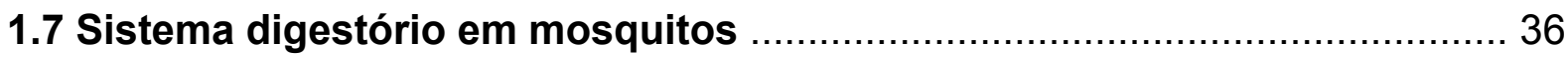

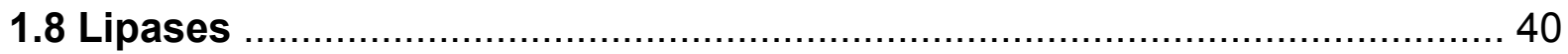

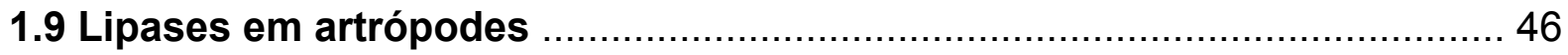

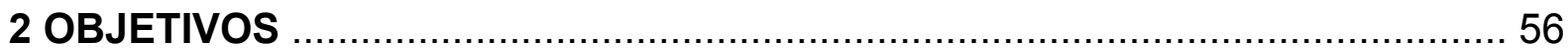

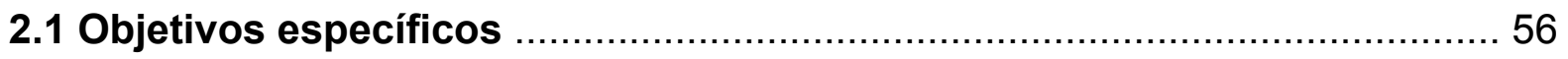

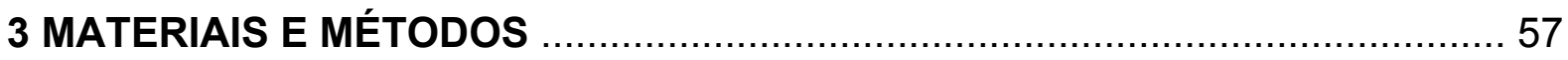

3.1 Manutenção e dissecção dos mosquitos Ae. aegypti ................................ 57

3.2 Ensaios enzimáticos e quantificação de proteína ……………................... 58

3.2. 1 Substratos fluorimétricos para deteç̧ão de lipase ...................................... 58

3.2.2 Substrato colorimétrico para deteç̧ão de lipase .......................................... 60

3.2.3 Ensaio titrimétrico para detecção de lipase ................................................. 60

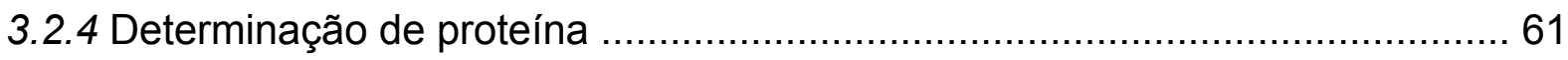

3.3 Extração de RNA total de intestino médio, resto de corpo (carcaça) e

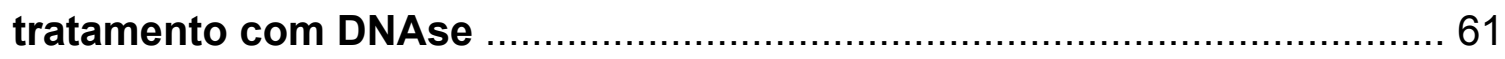

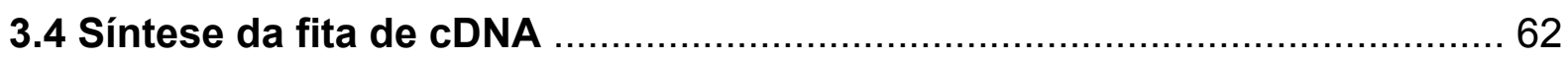

3.5 Reação em cadeia com DNA polimerase em termociclador (RT-PCR) ....... 62

3.6 Análise da expressão do gene de lipase AAEL007055 no intestino médio em fêmeas adultas do mosquito Ae. aegypti ............................................ 63

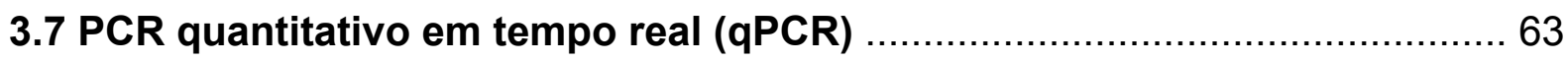

3.8 Infecção dos mosquitos Ae. aegypti pelo parasita $P$. gallinaceum ............. 64

3.8.1 Análises de expressão de lipase na infecção por $P$. gallinaceum .................. 65

3.9 Infecção dos mosquitos Ae. aegypti por DENV2 e análise da expressão da lipase L-Aa7055 
3.10 Clonagem e expressão das lipases provenientes das diferentes fases de desenvolvimento do mosquito Ae. aegypti (larva e adulto)

3.10.1 PCR com iniciadores específicos para clonagem em pET-SUMO, pAE e pOP 70

3.10.2 Eletroforese de DNA em gel de agarose ............................................ 70

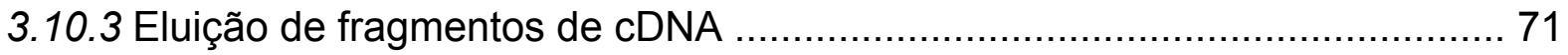

3.10.4 Ligação dos fragmentos de cDNA em plasmídeo vetor ........................... 71

3.10.5 Transformação de bactérias competentes ........................................ 72

3.10.6 Purificação de plasmídeos a partir de cultura bacteriana .......................... 72

3.10.7 Reação de sequenciamento de DNA .............................................. 73

3.10.8 Clonagem e expressão em pET-SUMO ............................................ 73

3.10.9 Clonagem e expressão em pAE ................................................... 73

3.10.10 Clonagem e expressão em pOP ................................................. 74

3.10.11 Procedimento para lise das células bacterianas .................................. 75

3.11 Processo de renaturação da lipase recombinante obtida em sistema de

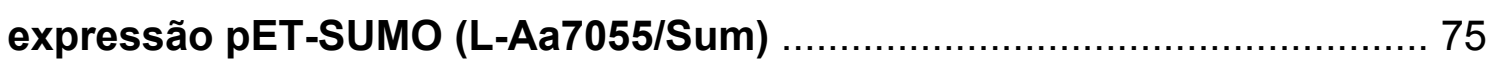

3.12 Verificação da lipase recombinante L-Aa7055/Sum por sequenciamento em LC-MS e da lipase proveniente de homogeneizado bruto em Orbitrap 76

3.13 Seleção de sequências, alinhamento e árvore filogenética .................... 77

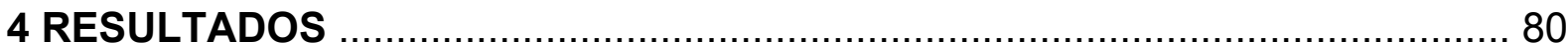

4.1 Alinhamento das lipases digestivas de Ae. aegypti com as lipases digestivas descritas 80

4.2 Determinação das lipases envolvidas na digestão em diferentes fases do desenvolvimento do mosquito Ae. aegypti 89

4.3 Expressão da lipase digestiva (L-Aa7055) na infecção por $P$. gallinaceum ....

4.4 Expressão da lipase digestiva (L-Aa7055) na infecção por DENV2 96

4.5 Clonagem e expressão das lipases digestivas presentes no intestino médio de fêmeas adultas (L-Aa7055) e larvas (L-Aa7051) ................................. 96

4.5.1 Expressão das lipases L-Aa7055 e L-Aa7051 em vetor pAE ....................... 96

4.5.2 Expressão da lipase L-Aa7055 em vetor pOP ......................................... 98

4.5.3 Expressão das lipases L-Aa7055 e L-Aa7051 em vetor pET-SUMO ............. 99 
4.6 Determinação da atividade e efeito da concentração de Oleato sob a atividade da lipase L-Aa7055/Sum após a renaturação ......................... 102

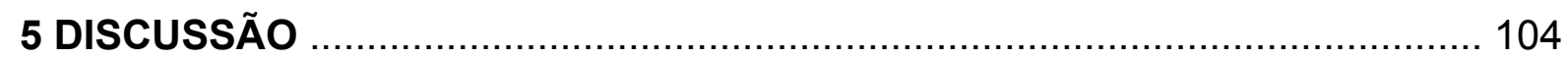

5.1 Características estruturais das lipases L-Aa7051 e L-Aa7055 .................. 104

5.2 Clonagem e expressão das lipases L-Aa7051 e L-Aa7055 em sistema recombinante 107

5.3 Lipases presentes nas fases de desenvolvimento do mosquito Ae. aegypti . 108

5.4 Resposta da expressão da lipase L-Aa7055 na infecção por $P$. gallinaceum . 


\section{INTRODUÇÃO}

Existem mais de 100 arbovírus que podem causar doenças em humanos, sendo que muitas destas são responsáveis por problemas significativos de saúde pública em todo o mundo. A maior parte desses tipos virais são transmitidos por mosquitos e incluem vírus dos gêneros flavivírus, alphavírus e bunyavírus (CIOTA; KRAMER, 2010).

A incidência de doenças transmitidas por mosquitos como a dengue, febre amarela, encefalite japonesa, vírus do Nilo ocidental, chikungunya, zika e até mesmo doenças parasitárias como a filáriose linfática, tem aumentado. Este fato é decorrente de múltiplos fatores como o aumento do trânsito humano em viagens, a urbanização desordenada, políticas falhas de infraestrutura e saneamento básico, medidas de prevenção ineficientes e mudanças climáticas (ADAMS; KAPAN, 2009; CHEN; WILSON, 2010; GOULD; SOLOMON, 2008; GUBLER, 2002; MUSSO; GUBLER, 2016).

O mosquito Ae. aegypti é um vetor competente para diversas arboviroses. Algumas delas se destacam por sua importância em saúde pública como febre amarela, dengue e mais recentemente chikungunya e zika. Estas doenças emergiram no Brasil e em países do continente americano causando epidemias e a infecção pelo vírus zika foi associada a complicações neurológicas (MUSSO; GUBLER, 2016; NUNES et al., 2015; VEGA-RÚA et al., 2015).

As fêmeas adultas do mosquito obtém os nutrientes necessários para a maturação dos ovos na alimentação sanguínea. Neste processo o animal pode se tornar infectado, pela ingestão de sangue contaminado do hospedeiro ou transmitir microorganismos, caso esteja infectado. O mosquito está intimamente associado à presença humana, tanto pelas condições necessárias para a sua reprodução, favorecidas no ambiente peridomiciliar, quanto por ser o homem o seu hospedeiro preferencial (HARRINGTON; EDMAN; SCOTT, 2001).

Algumas das principais arboviroses de importância em saúde pública, relacionadas ao mosquito $A e$. aegypti, estão descritas a seguir. 


\subsection{Febre Amarela}

A febre amarela é causada por um vírus do gênero Flavivirus, sendo este um vírus de RNA de cadeia simples e com polaridade positiva. A hipótese mais comum da origem desse vírus nas Américas está relacionada a introdução dele juntamente com o Ae. aegypti durante as trocas de escravos proveniente da África (MONATH, 2005; BRYANT; HOLMES; BARRET, 2007).

A febra amarela é uma doença infecciosa aguda, não contagiosa, que se mantêm endêmica em regiões da África e da América do Sul. Sua importância epidemiológica advém do elevado potencial de disseminação, do risco de reurbanização da transmissão e da gravidade clínica da doença, com taxa de letalidade em torno de 50\% entre os casos graves (MINISTÉRIO DA SAÚDE, 2014).

A doença é caracterizada por possuir dois ciclos distintos de transmissão, 0 ciclo silvestre e o urbano. Atualmente, no Brasil e na maior parte dos países onde é registrada, observamos apenas o ciclo silvestre da doença que envolve surtos epizoóticos causado pelos mosquitos dos gêneros Haemagogus e Sabethes em primatas não humanos (macacos). As populações que residem próximo a galerias fluviais de florestas são afetadas por esses surtos que levam a infecções esporádicas em humanos.

O ciclo urbano da doença envolve o homem como principal hospedeiro e a transmissão pelo mosquito Ae. aegypti. Por um longo tempo a ocorrência deste ciclo não era mais observado devido ao controle eficiente do vírus que é baseado na vacina 17D. Ainda assim, falhas na implementação e na manutenção do programa de vacinação representam fatores de risco para a reemergência da doença no Brasil e no mundo (BRASIL, 2010; FIGUEIREDO, 2016; WEAVER; REISEN, 2010).

Em dezembro de 2015, um surto de febre amarela foi registrado em cidades de Angola, o que sugere o reestabelecimento do ciclo urbano da doença, sendo que o último surto urbano de grandes proporções ocorrido na África havia sido registrado em 1986-87 na Nigéria, com números de casos estimados em 120.000 e 24.000 mortes (WOODALL; YUILL, 2016). Em Angola, o último surto havia ocorrido em 1988 com 37 casos e 14 mortes. Apesar de esforços na distribuição de aproximadamente 12 milhões de doses da vacina no país o surto atual continuou, e em 20 de maio de 2016 foram reportados 2420 casos suspeitos incluindo 298 mortes (WORLD HEALTH ORGANIZATION, 2016a). Os casos não ficaram restritos 
a Angola, o vírus já foi disseminado atráves de viajantes infectados provenientes de Angola para a República Democrática do Congo, Quenia e China. Os casos reportados na República Democrática do Congo também foram reportados em cidades (BARRETT, 2016), sendo o ciclo urbano da doença.

No ano de 2013 na África foram estimados 130.000 casos sintomáticos da doença com febre, icterícia ou hemorragias incluindo 78.000 mortes. A estimativa de redução de casos e mortes pelas campanhas de vacinação é de $27 \%$, alcançando uma redução de $82 \%$ em países selecionados para campanhas de vacinação em massa (GARSKE et al., 2014).

\subsection{Dengue}

O vírus dengue (DENV), é um vírus de RNA de fita simples com polaridade positiva pertencente ao gênero Flavivirus (família Flaviviridae) assim como o vírus da febre amarela. O RNA viral é empacotado pelas proteínas do capsídeo do vírus, que são rodeadas por uma bicamada fosfolipídica derivada do hospedeiro, onde estão incorporadas as proteínas do envelope (E) e membrana (M), arranjadas em uma geometria icosaédrica (MUKHOPADHYAY; KUHN; ROSSMANN, 2005). A poliproteína codificada por esse vírus é composta de três proteínas estruturais: proteína do capsídeo $(\mathrm{C})$, proteína precursora da membrana (prM), que é clivada para formar a proteína $M$ madura, a proteína do envelope $(E)$ em conjunto com outras proteínas não estruturais. As proteínas E e M estão inseridas na bicamada por domínios transmembrana (TM) em forma de hélice que se estendem para as regiões externas, no caso da proteína $E$, se conectando a um grande domínio externo (Figura 1) (MARZINEK et al., 2016). Essa extensão proteica recobre toda a superfície externa do vírus. 


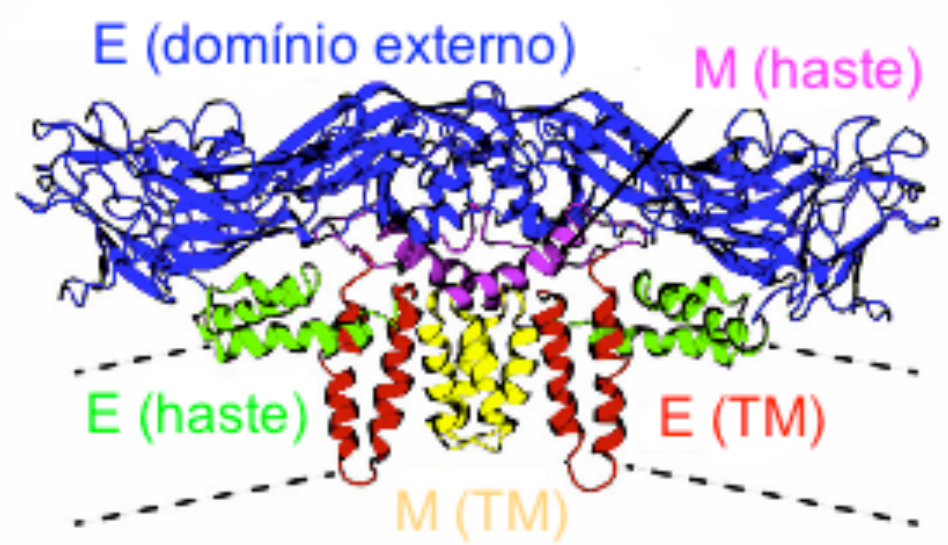

Figura 1 - Representação do dímero de proteína E/M de DENV-2 (PDB:3J27). A) As diferentes regiões estão coloridas separadamente e nomeadas. Para a proteína E, o domínio externo (resíduos 1-395, em azul), região das hastes (resíduos 396-449, em verde) e região transmembrana (TM) (resíduos 450-495, em vermelho). Para as proteínas $\mathrm{M}$, as diferentes regiões são haste (resíduos 1-38, em rosa) e TM (resíduos 39-72, em amarelo). As linhas tracejadas representam a localização aproximada da bicamada fosfolipídica. Fonte: Marzinek et al., (2016).

O DENV apresenta quatro sorotipos antigenicamente distintos que são geneticamente relacionados (DENV 1 ao 4). Os quatro sorotipos do vírus causam a mesma manifestação clínica da doença e mostram um padrão de disseminação, com tropismo por monócitos, macrófagos e células dentríticas (ROTHMAN, 2011).

O aspecto clínico da doença é variável, sendo que muitos casos são assintomáticos. Comumente a infecção causa febre repentina com sinais e sintomas variados incluindo: dor de cabeça frontal, dor retro-orbital, dores no corpo, náusea e vômito, dores nas juntas, fraqueza e "rash" cutâneo. A apresentação severa da doença, chamada de dengue hemorrágica, apresenta sinais de aumento na permeabilidade vascular, desordem na homeostasia e danos aos órgãos (GUBLER, 1998).

Todos os sorotipos da doença são capazes de induzir a hemorragia, sendo que fatores como interação com o hospedeiro e resposta imune a infecção prévia podem interferir causando maior severidade da doença. Fatores ligados ao vírus, como taxa de replicação, também determinam a virulência. Um estudo recente apontou para um número maior de casos severos da doença na infecção por DENV2 e outro mostrou que o sorotipo DENV-4 apresenta maior disseminação na coinfecção com DENV-1 (VICENTE et al., 2016; VAZEILLE et al., 2016). 
A dengue foi reintroduzida no Brasil em 1986 depois de uma ausência de aproximadamente 20 anos. Os quatro sorotipos circulam atualmente no país, DENV1 foi reintroduzida no Rio de Janeiro em 1986, DENV-2 em 1990, DENV-3 em 2002 e DENV-4 em Boa Vista no ano de 2010, alcançando outros estados do Norte (Amazonas e Pará), Nordeste (Piauí, Pernambuco, Bahia e Ceará), Sudeste (Rio de Janeiro e São Paulo) e Sul (Rio Grande do Sul) (BERTOLACCI-ROCHA et al., 2014; RODRIGUEZ-BARRAQUER et al., 2011; TEMPORÃO et al., 2011). Os vírus são transmitidos para o hospedeiro humano por mosquitos do gênero Aedes. Para isso o DENV precisa infectar as células epiteliais, se replicar e disseminar na hemocele, para finalmente infectar as glândulas salivares, o que é essencial para a transmissão do vírus ao hospedeiro humano.

Existem evidencias de que o sistema traqueal pode facilitar a contaminação de outros tecidos. As traquéolas que possuem um diâmetro de 0,2 a $1 \mu \mathrm{m}$ são preenchidas com fluidos e entram em contato com todos os tecidos do inseto. $O$ sistema traqueal apresenta taxas de infecção de 26 a $50 \%$ nos primeiros dias de infecção. Após a disseminação praticamente concomitante do vírus pelo intestino, sistema traqueal e abdômen o vírus infecta os lobos distais laterais das glândulas salivares. Os lobos medial e proximal desenvolvem a infecção posteriormente. Os lobos distais laterais participam proeminentemente da secreção de enzimas e proteínas envolvidas na hematofagia, portanto a infecção dessa região pode promover a transmissão precoce do vírus o que pode ocorrer 4 dias após a infecção. O pico do título viral no mosquito é observado entre 7 e 10 dias após a infecção (SALAZAR et al., 2007; STEINERT; LEVASHINA, 2011).

Um esforço de seis décadas no desenvolvimento de uma vacina para dengue culminou no licenciamento de uma vacina tetravalente chamada Dengvaxia (Sanofi Pasteur, Lyon, Rôdano-Alpes, França) em dezembro de 2015. Essa vacina é uma mistura quimérica do vírus da febre amarela atenuado contendo genes estruturais da pré-membrana e proteínas do envelope dos quatro sorotipos de DENV (1-4). Testes de fase $2 b$ na Tailândia mostraram uma eficácia de apenas $30,2 \%$, enquanto testes de fase 3 na Ásia e América Latina demonstraram 56 a 61\% de eficácia contra dengue e 67 a $80 \%$ de eficácia contra hospitalização, por tornar a reação a infecção mais branda. A vacina apresentou uma proteção assimétrica de acordo com a idade dos grupos testados (DURBIN, 2016; HALSTEAD, 2016; SABCHAREON et al., 2012; VILLAR et al., 2015). 
A WHO (2016b) estima que 3,5 bilhões de pessoas, ou seja, metade da população mundial, esteja sob risco de infecção pelo vírus dengue. Um trabalho recente, que faz uso de um banco de dados com informações precisas da ocorrência de dengue, estima 390 milhões de infecções anuais das quais 96 milhões são sintomáticas (BHATT et al., 2013).

A primeira estimativa calculada para os custos globais de dengue foi de US\$ 39,3 bilhões, o que corresponde a aproximadamente US\$ 414 por caso sintomático de dengue. Estes valores foram estimados levando em consideração fatores como: perda da produtividade, morte prematura e utilização de sistemas de saúde (SELCK; ADALJA; BODDIE, 2014). Entretanto, estudos mais recentes tem aperfeiçoado a metodologia de cálculo, estimando o número de casos sintomáticos da doença em 2013 em 58,4 milhões, sendo 13,586 casos fatais. Quando esses valores são considerados o custo global anual da dengue foi de 8,9 bilhões de dólares. Os dados obtidos por Bhatt et al. (2013), foram testados por esse modelo e com os 96 milhões de casos sintomáticos anuais preditos o custo global aumentou em $54 \%$ sendo de 13,7 bilhões (SHEPARD et al., 2016).

\subsection{Zika}

A febre de zika apresenta uma sintomatologia variada podendo ser confundida com outras arboviroses como a dengue e chikungunya. Era considerada uma doença de implicação média até a ocorrência de dois grandes surtos onde foi associada com complicações neurológica severas, a síndrome de Guillain-Barré na Polinésia Francesa (2013-2014) e a microcefalia em neonatos no Brasil (2014-2015). Existe um grande potencial de emergência do vírus zika (ZIKV) em regiões infestadas pelos mosquitos vetores competentes como o Ae. aegypti e o Ae. albopictus (MUSSO; GUBLER, 2016).

O ZIKV foi primeiramente isolado em um macaco Rhesus na floresta de Zika em Uganda no ano de 1947. A infecção em humanos foi descrita primeiramente na Nigéria (África) em 1954. O primeiro surto reportado da febre de zika ocorreu em 2007 na ilha de Yap nos Estados Confederados da Micronésia; o que foi seguido de uma grande epidemia na Polinésia Francesa em 2013 e 2014, com um número estimado de 30.000 infecções sintomáticas. Surtos menores foram registados no Pacífico, em 2014 na Nova Caledonia, Ilhas Cook, Ilha de Páscoa; em 2015 em Vanuatu, Ilhas Salomão, Samoa e Fiji. Em 2015, o ZIKV emergiu pela primeira 
vez no continente americano (em março no Brasil). Em janeiro de 2016 a circulação de ZIKV era autóctone em mais de 20 países ou territórios da América do Sul, Central, Norte e Caribe. Em novembro de 2015 um surto foi registrado no oeste da África em Cabo Verde (MUSSO; GUBLER, 2016).

O ZIKV é um arbovirus do gênero Flavivirus da família Flaviviridae. Como outros Flavivirus são vírus de RNA de fita simples com polaridade positiva, com duas regiões flanqueadoras não codificantes (5' e 3' NCR). A ORF codifica uma poliproteína: 5'-C-prM-E-NS1-NS2A-NS2B-NS3-NS4A-NS4B-NS5-3'. O capsídeo $(C)$, pré-membrana (prM)/membrana $(M)$ e o envelope $(E)$ são as três proteínas estruturais e as outras sete são proteínas não estruturais (NS1, NS2A, NS2B, NS3, NS4A, NS4B e NS5) (FAYE et al., 2014).

Faye et al. (2014) sequenciaram os genes codificadores do envelope E e NS5 de 43 cepas isoladas entre os anos de 1947 até 2007 na África, Ásia e Oceania. Esse estudo filogenético sugere que as cepas africanas foram arranjadas em dois grupos, um cluster derivado da cepa protótipo ZIKV MR766 e o cluster Nigéria; enquanto o clado asiático é constituído pelo agrupamento das cepas Micronésia e Malásia. Vírus isolados da Costa do Marfim e Senegal foram encontrados em ambos os clusters co-circulantes no Oeste da África.

Análises filogenéticas mostraram uma única introdução do vírus nas Américas, com ocorrência estimada entre maio e dezembro de 2013, mais de 12 meses antes da detecção do ZIKV no Brasil. As análises mostraram que os vírus encontrados no Brasil formam um robusto grupo monofilético com o genótipo asiático e possui um ancestral em comum com o vírus que circulou na Polinésia Francesa (FARIA et al., 2016). A epidemia ocorrida na Polinésia Francesa foi associada a uma complicação neurológica severa, a síndrome de Guillain-Barré, sendo registrado um grande aumento no número do casos no período da epidemia. No período de novembro de 2013 a janeiro de 2014 foram registrados 42 casos da síndrome de Guillain-Barré, o número de casos reportados entre os anos de 2009 a 2012 foram de 5, 10, 3 e 3 respectivamente, os pacientes foram analisados e 93\% deles possuíam IgM contra ZIKV (CAO-LORMEAU et al., 2016).

No Brasil os primeiros casos de uma doença exantemática foram reportados no final de 2014, e desde fevereiro de 2015, um surto afetou milhares de pacientes no nordeste do Brasil, principalmente na Bahia, Pernambuco, Maranhão, Rio Grande do Norte e Paraíba. Em março, amostras sorológicas foram coletadas e analisadas 
na Universidade da Bahia, sendo o primeiro caso autóctone confirmado em 15 de maio. No começo de dezembro de 2015, 18 estados já possuíam transmissão autóctone do vírus nas regiões nordeste, noroeste, sudoeste, centro, oeste e sul. No final de dezembro de 2015, o número estimado de casos suspeitos da doença estava entre 440.000 a 1.300 .000 (CAMPOS; BANDEIRA; SARDI., 2015; HENNESSEY; FISCHER; STAPLES., 2016; ZANLUCA et al., 2015).

A emergência de ZIKV no Brasil foi associada a outra complicação neurológica, a microcefalia em neonatos. De 2010 a 2014 o número anual de casos de microcefalia reportados no Brasil variava de 150 a 200. A primeira suspeita da relação com o ZIKV foi verificada em outubro de 2015, devido a um aumento do número de casos em Pernambuco, nordeste do Brasil, sendo que no final de janeiro de 2016, foram reportados 3.893 casos provenientes de 13 estados e 724 municípios brasileiros (MUSSO; GUBLER, 2016).

De Aragão et al. (2016) verificaram que a maior parte dos neonatos infectados por ZIKV (95\%) apresentaram má formação durante o desenvolvimento cortical. A relação entre a doença e a microcefalia foi confirmada experimentalmente. Foi observado que a cepa brasileira do ZIKV cruza a placenta e causa microcefalia por ter como alvo as células progenitoras corticais, induzindo dessa forma a morte celular por apoptose e autofagia e debilitando o neurodesenvolvimento (CUGOLA et al., 2016).

Além da transmissão pelo mosquito vetor, foram reportados 4 casos de transmissão sexual envolvendo homens previamente infectados. O primeiro caso de transmissão mulher para homem foi descrita no mês de julho de 2016 (DAVIDSON et al., 2016; MUSSO et al., 2015).

O diagnóstico da febre de zika pode ser feito pela detecção do antígeno em tecidos autopsiados, através de análises imunohistoquímicas com anticorpos monoclonais, associado a detecção molecular por PCR ou qPCR. As análises por PCR/qPCR são baseadas na detecção do RNA do Flavivirus. O método pode ser inespecífico pela amplificação de outros vírus do mesmo gênero. O teste molecular mais preciso é o sequenciamento, permitindo a identificação da espécie viral. $O$ diagnóstico também pode ser sorológico, sendo realizado por ELISA com confirmação por PRNT (neutralização por redução de placas de lise), que é um teste caro e requer uma estrutura laboratorial especializada devido a manipulação do vírus. O diagnóstico sorológico não é indicado em uma população onde há 
circulação de outros Flavivirus, por possível reação cruzada nos ensaios de IgM e IgG podendo resultar em falso positivo.

O indicado em países com poucos recursos laboratoriais é a realização de um teste IgM por ELISA combinado com a presença do antígeno NS1 e teste rápido de dengue. No caso de negativo para DENV a recomendação é que seja realizado o envio da amostra seca em papel de filtro para análise molecular. Em países com capacidade laboratorial o diagnóstico de primeira linha é o RT-qPCR com eliminação de suspeita para dengue e chikungunya pelo mesmo método (MUSSO; GUBLER, 2016).

\subsection{Chikunguya}

O vírus chikungunya (CHIKV) é um Alphavirus da família Togaviridae. Os Alphavirus são pequenos, envelopados e esféricos com RNA genômico de fita única de polaridade positiva. O genoma viral é envolto por um capsídeo proteico, e é envelopado por uma membrana composta por uma bicamada lipídica. Nessa membrana, estão inseridas as glicoproteínas E1 e E2 que formam espinhos triméricos de heterodímeros. A proteína E2 é responsável pela ligação a receptores da membrana do hospedeiro enquanto a proteína E1 é a proteína de fusão (FIELDS; KIELIAN., 2015).

O CHIKV é originário da África, onde circula em ciclo silvestre que envolve primatas não humanos e mosquitos do gênero Aedes. É tipicamente transmitido entre humanos pelos vetores antropofílicos Ae. aegypti e Ae. albopictus. O vírus foi descoberto durante um surto ocorrido na atual Tanzânia em 1952-1953 (WEAVER; FORRESTER, 2015).

Quatro linhagens de CHIKV foram identificados depois de sua descoberta. As linhagens leste/central/sul africana (ECSA) e oeste africana participam do ciclo silvestre, são endêmicas e causam epidemias na África subsaariana. A linhagem asiática, derivada de ECSA, circula entre humanos e o mosquito Ae. aegypti em um ciclo de transmissão urbana sendo responsável por surtos na Índia e sudoeste da Ásia na década de 60. A linhagem do Oceano Índico (IOL), também derivada da linhagem ECSA, foi identificada inicialmente no Quênia em 2004 sendo responsável por epidemias em ilhas do Oceano Índico e Ásia entre 2005 e 2011 (NUNES et al., 2015; WEAVER, 2014). 
Dessas epidemias a melhor estudada foi a da ilha Reunião, com mais de 300.000 casos. O sequenciamento genômico dessa linhagem mostrou uma mutação em um aminoácido na posição $226(A-V)$ no envelope glicoproteíco $E 1$, que é uma região conhecida como facilitadora da infecção em células do mosquito $A e$. albopictus (TSETSARKIN et al., 2007). Durante o pico da epidemia com a linhagem IOL a doença foi trazida por viajantes causando pequenos surtos no norte da Itália e no sul da França, onde esse mosquito circula (GRANDADAM et al., 2011; REZZA et al., 2007).

Casos autóctones não foram detectados no ocidente até o final de 2013, quando foram observados casos na llha de São Martin no Caribe. Subsequentemente o CHIKV se disseminou por todas as ilhas do Caribe e para a América do Norte, Sul e Central, sendo registrados 1.231 .077 casos em 43 países desse continente. A cepa identificada não era a IOL responsável pelas epidemias recentes, mas pertenciam a linhagem asiática. No Brasil por volta de setembro de 2014, a transmissão autóctone da linhagem asiática foi confirmada no Amapá. Em junho de 2014 um viajante da Angola introduziu a linhagem ECSA no estado da Bahia, em Feira de Santana, com casos autóctones confirmados em setembro de 2014 (HONÓRIO et al., 2015; MINISTÉRIO DA SAÚDE., 2015; NUNES et al., 2015).

A doença possui uma sintomatologia parecida com a do vírus dengue (DENV), que se manifesta após um período de 2 a 4 dias após a picada do mosquito. A viremia persiste por mais de 5 dias após o inicio dos sintomas, sendo caracterizada por febre alta, intensa artralgia principalmente pela manhã, dor nas costas e dor de cabeça. As presença do vírus pode ser detectada nas juntas até 90 dias após a infecção (FIGUEIREDO; FIGUEIREDO, 2014).

O diagnóstico pode ser realizado por ensaios moleculares nos primeiros estágios virêmicos com uso de PCR e qPCR, com primers degenerados para Alphavirus ou primers específicos que amplificam os genes nsP1, nsP2 ou E1. A resposta sorológica para CHIKV pode ser detectada por ensaios imuno enzimáticos, ensaio de imunofluorescência indireta, inibição da hemoaglutinação e teste de neutralização, entretanto o diagnóstico da infecção não pode ser baseado exclusivamente em testes sorológicos, pois podem ocorrer reações cruzadas com outros vírus (FIGUEIREDO; FIGUEIREDO, 2014).

Atualmente a doença é um grande problema pois causa epidemias de grande magnitude, é altamente debilitante e não tem nenhum tratamento ou vacina. 


\subsection{Malária}

A malária é a doença parasitária tropical mais mortal enfrentada pelo homem. Estimativas baseadas em dados globais da mortalidade apontam que no ano de 2010 a doença foi responsável por 1,2 milhões de mortes (MURRAY et al., 2012). A malária é causada por parasitas do gênero Plasmodium, que são transmitidos ao homem pela picada de fêmeas infectadas do mosquito Anopheles. Em um relatório recente, a Organização Mundial da Saúde estimou que ocorreram 214 milhões de casos de malária no ano de 2015, com aproximadamente 430.000 mortes (WHO, 2016c).

Aproximadamente 3,2 bilhões de pessoas estão sobre risco de adquirir malária, número que corresponde a quase metade da população mundial. $\mathrm{Na}$ década passada ocorreu um movimento global de combate a malária, sendo um esforço combinado de organizações privadas como a Fudação Bill \& Melinda Gates em 2007 e de governos nacionais como anunciado pelo secretário-geral da Organização das Nações Unidas em 2011. Como resultado desse esforço, dados obtidos entre os anos de 2000 até 2015 mostraram uma redução global da incidência da doença de $37 \%$, bem como uma redução da taxa de mortalidade global de $60 \%$ em grupos de idade variadas e de $65 \%$ em crianças abaixo de 5 anos (WHO, 2016d). Apesar desses dados a doença ainda é uma das maiores causadoras de mortes.

O combate a doença tem sido realizado em diversas frentes, a utilização de drogas antimaláricas é recomendada para viajantes e em mulheres grávidas de áreas endêmicas, o uso de redes tratadas com inseticida bem como o uso de inseticidas dentro das casas. Entretanto, o controle do vetor é o principal meio de prevenção e redução da transmissão da malária. A utilização das drogas como tratamento da doença e de inseticidas no combate ao mosquito tem levado ao aumento da resistência a essas drogas e aos inseticidas existentes, o que mostra e necessidade da ampliação do estudo de biomoléculas para desenvolvimento de noas drogas e o investimento em alvos vacinais efetivos (WHO, 2016d).

Em novembro de 2016 a primeira vacina contra malária será lançada em projetos piloto na África subsaariana. A vacina chamada RTS,S age contra o Plasmodium falciparum, o parasita mais letal causador da malária, sendo o mais prevalente na África. Testes clínicos avançados mostraram que a vacina apresentou proteção parcial contra malária em crianças pequenas e tem sido proposta como 
uma ferramenta complementar ao pacote de prevenção, diagnóstico e medidas de tratamento recomendadas (AGNANDJI et al., 2012; WHO, 2016e).

O Plasmodium tem um ciclo de vida complexo que envolve dois diferentes hospedeiros: o hospedeiro vertebrado (humano) e o invertebrado (mosquito). Para que a transmissão ocorra, o Plasmodium precisa completar seu ciclo no mosquito.

\subsubsection{O ciclo de vida do Plasmodium sp no mosquito}

Quando se alimenta do sangue do hospedeiro humano infectado, a fêmea do mosquito ingere os gametócitos machos e fêmeas do Plasmodium que se diferenciam em micro e macrogametas, respectivamente, resultando na fertilização e estabelecimento dos zigotos. Os zigotos presentes no lúmen do intestino se transformam em oocinetos móveis, responsáveis pela invasão transversal do epitélio, o que ocorre aproximadamente 1 dia após a ingestão do sangue e é crucial para seu estabelecimento e o sucesso da infecção. Após a invasão do epitélio o parasita precisa alcançar a lamina basal, onde se desenvolve em oocistos (Figura 2).

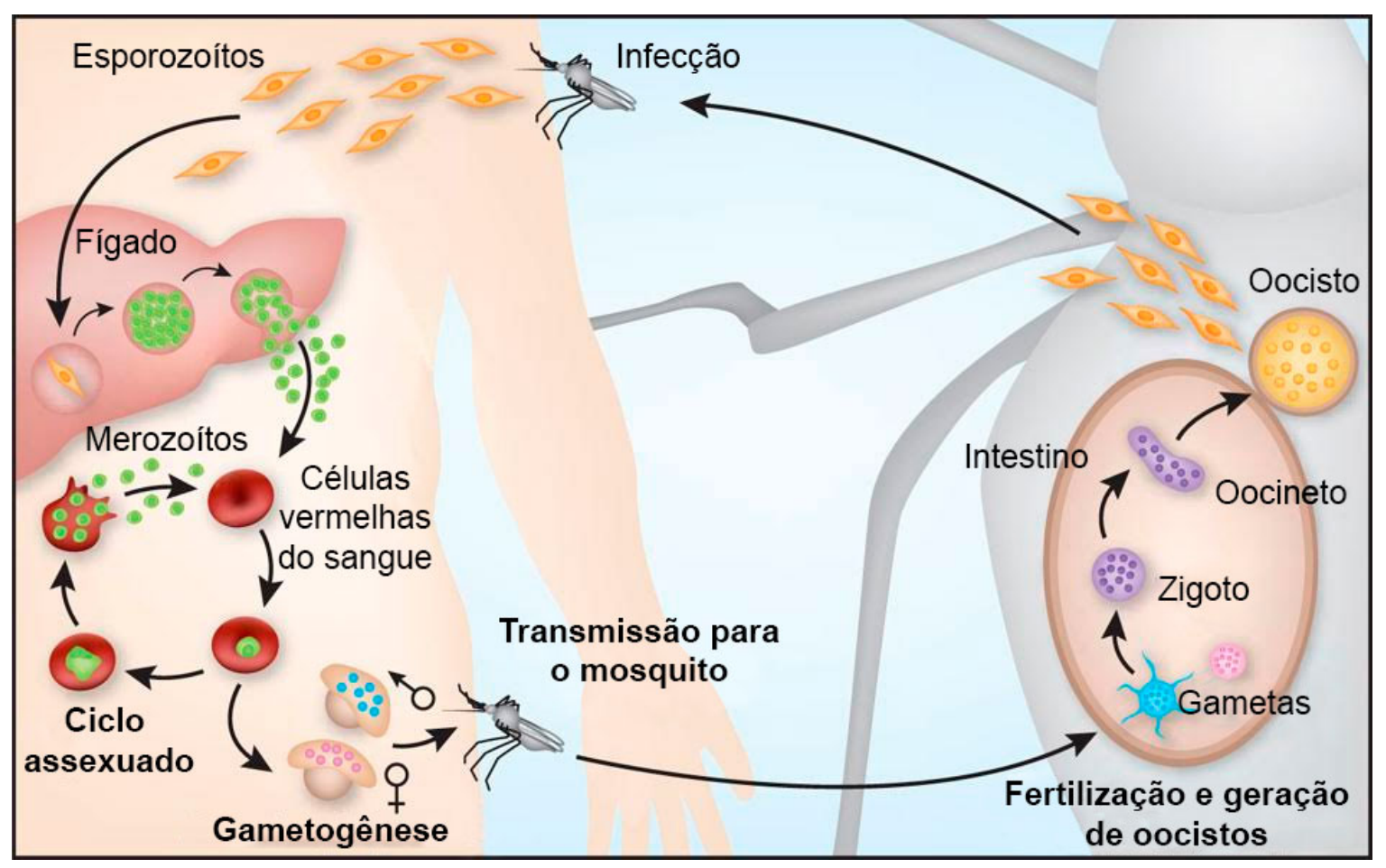

Figura 2 - Ciclo do desenvolvimento do Plasmodium no hospedeiro vertebrado e invertebrado. Fonte: PASVOL (2010). 
A invasão do epitélio intestinal é um grande desafio para o parasita devido a presença de barreiras físicas e químicas (BATON; RANFORD-CARTWRIGHT, 2007). Fisicamente o parasita deve trespassar a membrana peritrófica e o próprio epitélio intestinal. A membrana peritrófica começa a se formar após a alimentação sanguínea e fica madura em 24 horas, coincidindo com o início da invasão pelo Plasmodium. O animal também secreta enzimas digestivas que funcionam como uma barreira química. A eficiência dessas barreiras fica clara quando observamos que os inicialmente milhares de oocinetos resultam em aproximadamente meia dúzia de oocistos maduros (WANG; JACOBS-LORENA, 2013).

O parasita expressa quitinases micronemais em sua superfície para degradar e permitir a invasão do parasita através da membrana peritrófica. O oocineto precisa se alojar perto da membrana basal para poder se desenvolver em oocistos. Existem múltiplos receptores na membrana do epitélio que podem modular o processo de invasão, como por exemplo a proteína ligadora de enolase. A presença da enolase de superfície do oocineto está envolvida no reconhecimento do receptor presente no intestino médio. A enolase também possui uma segunda função, a de captura de plasminogênio do soro presente no sangue ingerido que é convertido a plasmina, uma serino proteinase que auxilia no processo de invasão. Aproximadamente 14 dias após a ingestão do sangue, os oocistos liberam milhares de esporozoitos que migram para as glândulas salivares do mosquito tornando o mosquito infeccioso (DANA; HONG; KERN, 2005; GHOSH; JACOBS-LORENA, 2011; GHOSH, 2014; SARAIVA et al., 2016; VEGA-RODRÍGUEZ; MUKHERJEE et al., 2016).

Todos os patógenos transmitidos por mosquitos são adquiridos através da alimentação sanguínea. Portanto, em algum ponto do ciclo de vida os parasitas permanecem e têm que superar a barreira do intestino para alcançar o local específico de desenvolvimento no hospedeiro, permitindo a transmissão destes parasitas para o hospedeiro humano. O sistema digestório tem como principais funções o processamento e obtenção de nutrientes, a proteção do organismo em forma de barreiras químicas e físicas como já discutido e na ativação do sistema imune. O entendimento do funcionamento do sistema digestório é necessário para obtenção de estratégias de controle eficientes, devido à sua importância na interação parasita/hospedeiro. 


\subsection{Ciclo de vida do mosquito Ae. aegypti}

Mosquitos adultos são insetos terrestres voadores. Em contrapartida seus estágios imaturos, larvas e pupas, são aquáticos. O ciclo de vida do mosquito é complexo, envolve grandes transformações fisiológicas com consequente necessidade de um grande aporte energético.

Os ovos do mosquito $A$ e. aegypti (Figura 3) são resistentes a dessecação, podendo permanecer viáveis no ambiente, em estado de quiescência, por até um ano. A deposição dos ovos é realizada em recipientes umedecidos ou com potencial capacidade de acúmulo de água; assim, com o aumento da umidade e disponibilidade de água no criadouro, as larvas eclodem. Portanto, o mosquito Ae. aegypti não necessita de grandes coleções de água para sua reprodução, e podem depositar seus ovos em qualquer recipiente que contenha água limpa (CONSOLI; LOURENÇO-DE-OLIVEIRA, 1998; FORATTINI, 2002; RESH; CARDÉ, 2009).

As larvas do mosquito passam por quatro estádios (L1-L4), sendo que este processo pode durar de cinco a dez dias. O tempo necessário para o desenvolvimento dos estádios larvais é dependente de diversos fatores, sendo o mais importante a temperatura da água, seguido por disponibilidade de alimento e densidade larval. A temperatura da água e a presença de alimento estão inversamente relacionadas ao tempo de desenvolvimento enquanto a densidade larval está diretamente relacionada (FORATTINI, 2002).

Após a conclusão da muda e esclerotização dos quatro estádios da fase larval, tem início a metamorfose, para a fase de pupas e posteriormente em adultos. Este é um processo complexo que envolve histólise e remodelamento das larvas e pupas para a formação dos tecidos do adulto. A cascata de eventos transcricionais associados com a ecdise e a metamorfose é controlada pela atividade coordenada dos hormônios juvenil e ecdisteróide (SEVERSON et al., 2013).

$\mathrm{Na}$ fase pupal, durante a qual não ocorre alimentação, o animal apresenta motilidade e foto-sensibilidade. Esta fase, assim como as demais, é dependente da temperatura e tem duração de dois dias (quando a temperatura é de $27^{\circ} \mathrm{C}$ ). Com o desenvolvimento do imago dentro da pupa ocorre a emergência do animal adulto, que permanece algumas horas no local para o enrijecimento do exoesqueleto. Após esse período, as fêmeas adultas estão prontas para a realização da cópula; já o 
macho, necessita de no mínimo 24 horas para seu amadurecimento, período no qual ocorrerá a torção de sua genitália e produção de esperma (FORATTINI, 2002).

As fêmeas adultas do mosquito Ae. aegypti precisam realizar apenas uma cópula, pois armazenam quantidade suficiente de esperma nas espermatecas para todo o período reprodutivo. Estas fêmeas têm como principal fonte protéica o repasto sanguíneo, que é realizado três dias após a cópula. O sangue é necessário para o processo de ovogênese (desenvolvimento e maturação dos ovos) bem como para ser utilizado como fonte de energia para o vôo. A fêmea adulta pode se alimentar do sangue de múltiplos hospedeiros humanos durante um único ciclo gonotrófico. A ocorrência de alimentação em um hospedeiro infectado pode levar à contaminação do mosquito durante o repasto sanguíneo. Desta forma, o sistema digestório é o primeiro ponto de contato do mosquito com o sangue infectado.

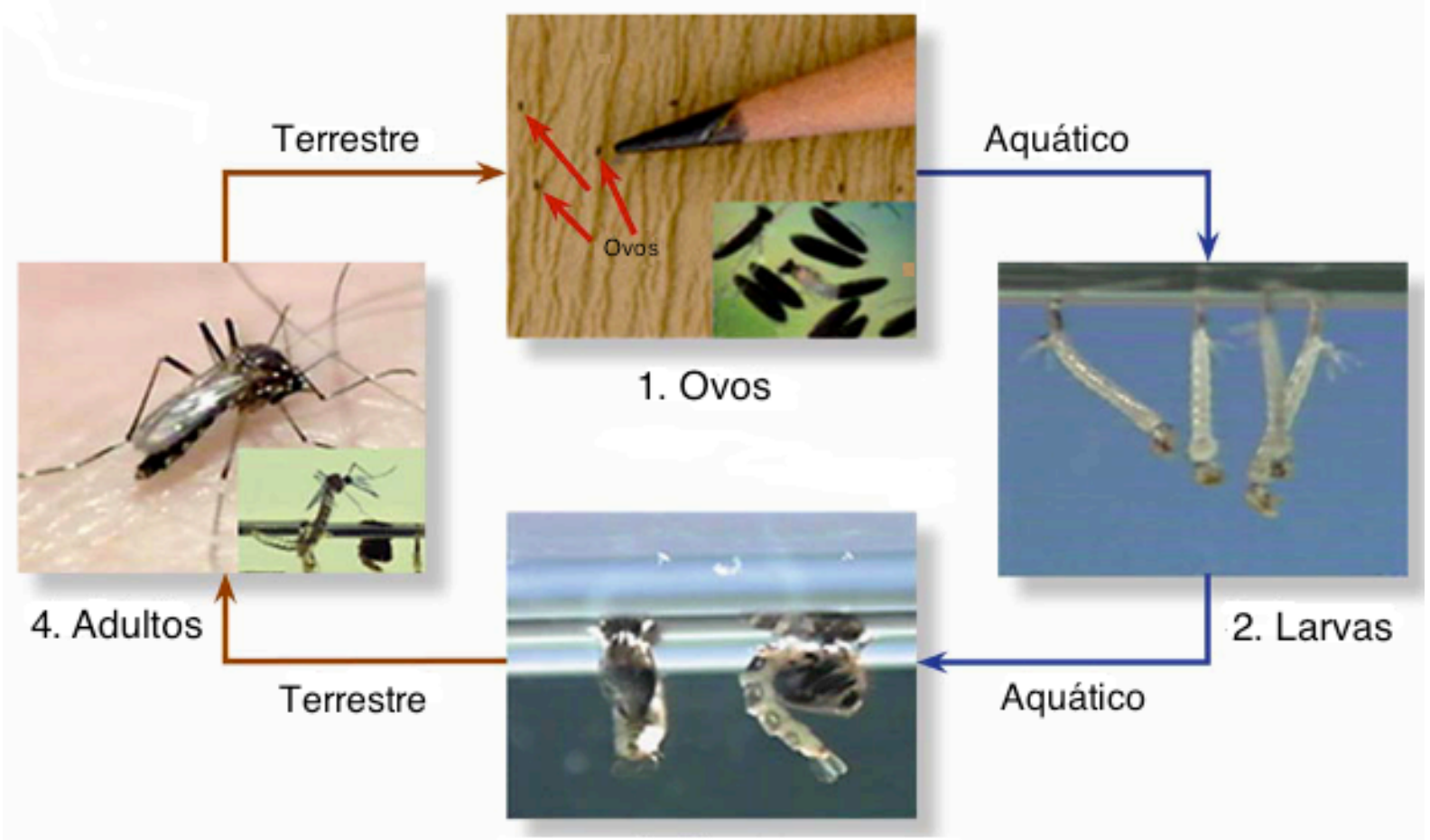

3. Pupas

Figura 3 - Ciclo de vida do mosquito Ae. aegypti. Neste esquema, as formas encontradas na fase terrestre (adultos e ovos) estão representadas por flechas marrons e na fase aquática (larvas e pupas) por flechas azuis. Em 1) Ovos (setas vermelhas); 2) Larvas; 3) Pupas e 4) fase adulta emergindo e no ambiente . Fonte: CENTERS FOR DISEASE CONTROL AND PREVENTION (2009); Urdaneta-Marquez e Faillloux (2010). 


\subsection{Sistema digestório em mosquitos}

O sistema digestório é composto basicamente pelas glândulas salivares e canal alimentar (intestino), e é responsável por todos os passos no processamento do alimento: secreção, digestão, absorção, processamento das fezes e eliminação.

A morfologia das glândulas salivares de fêmeas adultas dos mosquitos Ae. aegypti, Anopheles stephensi, Culex pipiens, Culex quinquefasciatus e Anopheles darlingi é bastante similar. Nos machos as glândulas consistem em um único lobo pequeno. As glândulas das fêmeas são compostas de três lobos que estão ligados a um duto salivar principal, o lobo medial é curto e dois lobos laterais são longos. Os lobos são estruturas acinares, organizadas como um epitélio unicelular que envolve o canal salivar. O lobo medial parece ser constituído por células secretoras, sendo dividido em duas porções, proximal e distal. Os lobos laterais têm pelo menos duas regiões secretoras a porção proximal e distal, que são separadas por uma porção medial não glandular (DA CUNHA SAIS, 2003; MOREIRA-FERRO; MARINOTTI; BIJOVSKY, 1999).

As moléculas presentes na saliva apresentam funções anti-hemostáticas (vaso dilatadores, anti-coagulantes e inibidores de fatores de agregação), imunomodulatórias e anti-inflamatórias que facilitam a aquisição do sangue e que acabam influenciando na transmissão de patógenos. A alimentação por açúcar também é auxiliada pela salivação que dilui açúcares sólidos, produz enzimas para digestão de açúcares complexos, peptídeos e enzimas como a lisozima, ambos com função antimicrobiana (GROSSMAN; CAMPOS; SEVERSON, 1997; SCHNEIDER; HIGGS, 2008; STYER et al., 2011; SUTHANGKORNKUL et al., 2015).

O intestino anterior e posterior são derivados da ectoderme sendo revestidos de epiderme e cutícula, enquanto o intestino médio tem origem endodérmica e é revestido por uma membrana quitino-protéica denominada membrana peritrófica. $O$ intestino anterior é responsável pela ingestão, armazenamento e processamento inicial do alimento prévio a digestão química. O intestino médio tem como funções a secreção de enzimas, a hidrólise e a absorção do alimento ingerido, absorção e secreção de água. $\mathrm{O}$ intestino posterior é responsável pela formação e armazenamento de fezes e pela reabsorção de água (RESH; CARDÉ, 2009; TERRA; FERREIRA, 1994; TERRA; FERREIRA, 2012).

O intestino das larvas (Figura 4) é dividido estruturalmente em três grandes 
regiões. A porção anterior, onde encontramos a cárdia. A porção média, onde observamos bolsas laterais chamadas de cecos (gástricos ou do intestino médio) e o intestino médio que inclui ventrículo (tubo longo e reto), que é revestido pela membrana peritrófica (MP) durante o processo digestivo. Na porção posterior estão localizadas as inserções dos túbulos de Malpighi e o reto. A MP é secretada por poucos arranjos de células localizadas na cárdia e é constiuída por fibras de quitina que são interligadas por proteínas chamadas peritrofinas. As peritrofinas da MP larval apresentam com um alto número de domínios ligadores de quitina (CBDs) e domínios do tipo mucina (VENANCIO et al., 2009).

$\mathrm{Na}$ fase larval o intestino possui um papel fundamental no desenvolvimento do mosquito. Larvas pequenas e mal alimentadas produzem adultos com potencial reprodutivo reduzido. Qualquer interferência no desenvolvimento normal do intestino médio pode reduzir a capacidade da larva de absorver e estocar nutrientes tendo como consequência a redução de sua fecundidade na vida adulta (RAY et al., 2009).

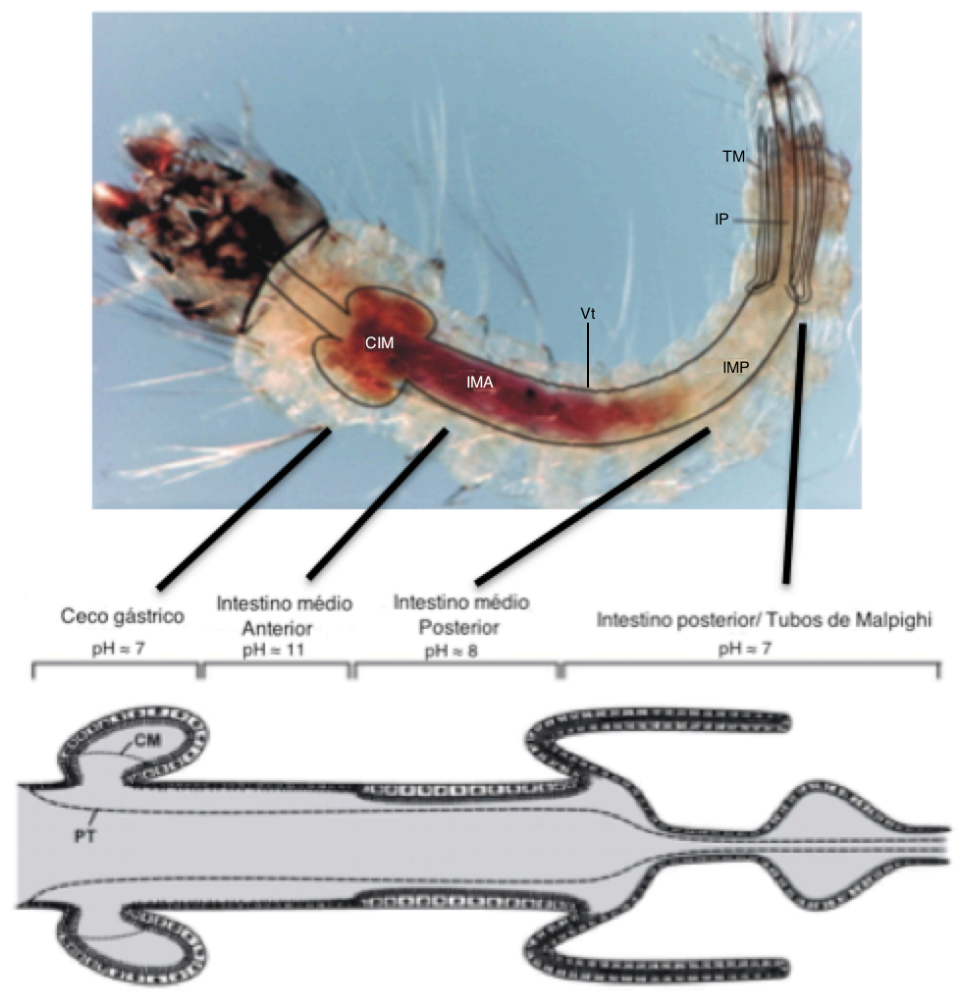

Figura 4 - Representação esquemática do sistema digestório de larvas de Ae. aegypti: (CIM) Ceco do Intestino médio, (Vt) Ventrículo, (IMA) Intestino médio anterior, (IMP) Intestino médio posterior, (IP) Intetino Posterior e (TM) Túbulos de Malpighi. Fonte: Linser et al. (2009). 
Em fêmeas adultas do mosquito Ae. aegypti o intestino médio (Figura 5), o canal alimentar, também é dividido em três regiões, intestino anterior, médio e posterior. O intestino anterior está envolvido primariamente com a ingestão, condução e estocagem do alimento. Três divertículos se originam da parte posterior do esôfago: dois da parte dorso lateral e um da parede ventral do intestino, e são revestidos de uma cutícula fina e impermeável. O divertículo ventral (DVv) ou papo, é grande e pode se estender por todo o abdômen. Geralmente os três divertículos estão preenchidos com bolhas de ar e são utilizados como reservatório de alimento, a alimentação com açúcar é estocada no divertículo e passa vagarosamente ao intestino onde é digerida. Esse mecanismo permite a fêmea do mosquito manter o estômago vazio, pronta para receber o repasto sanguíneo (GUSMÃO et al., 2007). Anexas ao intestino anterior estão as glândulas salivares que foram descritas anteriormente.

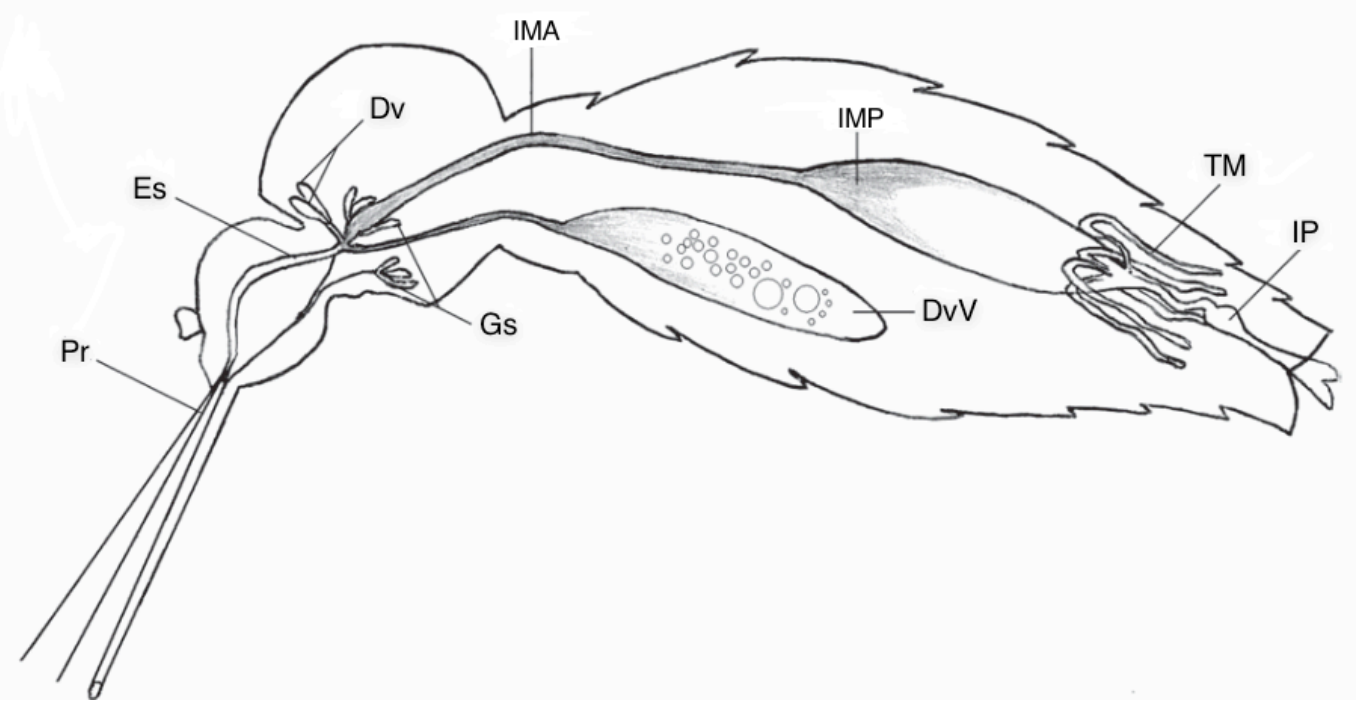

Figura 5 - Representação esquemática do sistema digestório de adultos de Ae. aegypti: (Pr) Probóscide, (Es) Esôfago, (Dv) Divertículos, (Gs) Glândula salivar, (DvV) Divertículo ventral, (IMA) Intestino médio anterior, (IMP) Intestino médio posterior, (TM) Túbulos de Malpighi, (IP) Intestino posterior. Fonte: Gusmão (2007).

O intestino médio é altamente elástico e revestido internamente por um epitélio colunar, adaptado a secreção e absorção. O intestino médio de fêmeas adultas é revestido pela MP após o repasto sanguíneo, que tem sua produção estimulada pela distensão do intestino que ocorre naturalmente após a ingestão do 
alimento. A formação da MP se torna evidente 4 a 5 horas após o repasto sanguíneo, adquirindo maturidade de espessura e textura por volta das 12 horas, com formação de camadas concêntricas tendo sua maturação completa por volta de 24 horas.

A MP é composta por quitina, proteínas e glicoproteínas, e circunda as células epiteliais e tem como função a proteção do epitélio contra danos físicos e químicos e a modulação da digestão do sangue (KATO et al., 2008). A presença de ferro e agregados de heme na membrana peritrófica apontam para uma possível função de barreira detoxificadora e existe até mesmo a suposição de que a presença do heme estaria envolvida na formação da membrana em Anopheles gambiae (MAGALHÃES, 2014). Diferente do observado na fase larval, as peritrofinas encontradas na membrana peritrófica no animal adulto apresentam um menor número de domínios ligadores de quitina (CBDs) e mucina, o que aponta para a influência da estrutura dos domínios peritrofina na arquitetura da membrana peritrófica (VENANCIO et al., 2009).

$\mathrm{Na}$ parte posterior do intestino médio existe um esfíncter, chamado válvula pilórica, após a qual ligam-se os tubos de Malpighi, cuja a estrutura e o tamanho se mantém praticamente intactos desde o último estágio larval até a fase adulta, envolvidos na reabsorção de água e excreção. Posteriormente se segue o intestino posterior, composto pelo íleo, o reto distendido e o ânus (CONSOLI; LOURENÇO DE OLIVEIRA, 1998).

A caracterização do sistema digestório tem auxiliado no desenvolvimento de estratégias de controle de mosquitos que tem o sistema digestório deste vetor como alvo como, por exemplo, o uso da espécie bacteriana Bacillus thuringiensis isrelensis (CANCINO-RODEZNO et al., 2012; DELÉCLUSE et al., 2000; SILVA et al., 2008) e o uso de RNA de interferência (GU et al., 2011), ambas visando a redução do tempo de vida do mosquito. A bactéria Bacillus thuringiensis, produz toxinas cristalinas inseticidas (Cry) que são formadoras de poros que afetam a permeabilidade da membrana celular e a integridade das células do intestino médio. $O$ atual mercado de biopesticidas corresponde a $2 \%$ de um mercado de proteção de colheitas estimado em 600 milhões de dólares, sendo $90 \%$ desses biopesticidas baseados em produtos relacionados ao Bacillus thuringiensis (SANCHIS; BOURGUET, 2008). O uso de RNA de interferência ainda é uma metodologia em desenvolvimento (MCGRAW; O'NEILL., 2013). 
Estudos com a utilização de RNA de interferência sobre peptidase do tipo tripsina presentes no intestino médio do mosquito Ae. aegypti mostraram que essa enzima tem um papel importante no desenvolvimento dos ovos e que a ausência de uma tripsina de expressão tardia nomeada 5G1 resulta em maiores taxas de infecção no intestino médio por dengue do tipo 2, evidenciando a ação de enzimas como fator limitante na infecção (BRACKNEY; FOY; OLSON, 2008; ISOE et al., 2009).

Encontramos na literatura a descrição de outras enzimas que, além de sua importância na digestão, têm papéis relacionados à defesa. Em Bombyx mori foi descrita a atividade antiviral de uma lipase digestiva (PONNUVEL et al., 2003). A função destas lipases seria a de hidrolisar a camada lipídica que reveste muitos vírus ou mesmo a bicamada lipídica de protozoários. Entretanto, pouco se conhece sobre as lipases em mosquitos e não se sabe se as lipases do mosquito Ae. aegypti apresentam uma função exclusivamente digestiva ou se existe algum efeito destas enzimas no processo infeccioso.

\subsection{Lipases}

Lipídeos constituem um grupo grande e heterogêneo de substâncias, e tem como característica serem insolúveis em água e facilmente solúveis em solventes apolares. A obtenção de ácidos graxos através da ingestão de lipídeos é indispensável pois estes estão envolvidos na estrutura celular e no metabolismo. Os triacilgliceróis (TAGs) são os principais lipídeos de reserva encontrados em animais e vegetais sendo constituídos por triésteres de ácidos graxos e glicerol e são a principal fonte de ácidos graxos na dieta. Após a ingestão, as ligações éster dos TAGs serão hidrolisadas durante o processo digestivo para que os ácidos graxos sejam absorvidos. Dentre as enzimas que hidrolisam ligações éster encontramos as hidrolases que atuam em ésteres carboxílicos (EC 3.1.1.), como é o caso das esterases, fosfolipases A e B e lipases.

A digestão de lipídeos em humanos é o processo de degradação e absorção de triacilglicerideos melhor caracterizado. Este processo envolve etapas distintas como: emulsificação, hidrólise por lipases em ácidos graxos e monoacilglicerol, dispersão dos produtos no ambiente aquoso e captação pelos enterócitos, sendo que este processo se inicia com a ação das lipases lingual e gástrica (MILED et al., 2000; MU; PORSGAARD, 2005). 
As lipases (EC 3.1.1.3.) podem ser divididas em 6 famílias com base na relação de suas sequências com o grupo estrutural das $\alpha / \beta$ hidrolases: lipases neutras, lipases ácidas, lipase 2, lipase 3, GDSL (esterases e lipases que possuem o motivo GDSL, distinto do tradicional GxSxG) o e lipases sensíveis a hormônios (DEREWENDA, 1994; HOLMQUIST, 2000).

As 6 famílias utilizam o mesmo mecanismo de reação baseado em uma tríade catalítica que é composta pelos resíduos Ser, Asp e His. Essa tríade catalítica é quimicamente análoga a tríade catalítica de serino peptidases, como quimotripsinas, mas são estruturalmente distintas. Nas lipases o resíduo de Ser catalítica, que é altamente conservado, está localizado em uma sequência consenso formada pelos aminoácidos Gly-X-Ser-X-Gly (GxSxG) (HOLMQUIST, 2000).

$\mathrm{Na}$ família das lipases neutras encontramos a lipase pancreática (LP), as proteínas relacionadas a lipase pancreática 1 e 2 (PRLP 1 e 2), lipase hepática (HL), lipase lipoproteína (LPL), lipase endotelial $(E L)$ e a fosfatidilserina fosfolipase $A 1$ (FLP A1). A lipase pancreática é sintetizada pelas células acinares do pâncreas sendo secretada no lumem intestinal onde auxilia na absorção de ácidos graxos de cadeia longa presentes em TAGs. As PRLP 1 e 2 também são encontradas no pâncreas em concentrações menores que a LP. A PRLP 1 não apresenta atividade enzimática, enquanto a PRLP 2 apresenta atividade tanto sobre TAG quanto sobre fosfolipídeos (WONG; SCHOTZ, 2002).

As outras lipases da família neutra atuam no metabolismo de lipoproteínas circulantes. A lipase hepática apresenta um papel na absorção de colesterol HDL e é sintetizada exclusivamente no fígado, com atividade sobre TAG, fosfolipídeos e partículas de HDL. A LPL é encontrada em uma variedade de tecidos com altas concentrações no tecido adiposo e no músculo. Essa lipase se liga ao epitélio capilar onde atua fornecendo os tecidos adjacentes com ácidos graxos provenientes de TAGs presentes no interior de quilomicrons e VLDL circulantes. A lipase endotelial é expressa pelas células vasculares endoteliais, células epiteliais da tireoide e hepatócitos e atua com alta hidrólise de fosfolipídeos em HDL apresentando pouca atividade sobre TAGs. A fosfatidilserina fosfolipase A1 tem preferencia por fosfatidilserina e lisofosfatidilserina (WONG; SCHOTZ, 2002; WANG et al., 2013).

$\mathrm{Na}$ família das lipases ácidas encontramos 7 lipases descritas em mamíferos, lipase lisossomal (LIPA), lipase gástrica (LG), uma lipase expressa em testículo (LIPJ), três outras lipases que são expressas nas células da epiderme (LIPK, LIPM e 
LIPN) e uma lipase descrita em glândulas salivares de ratos e camundongos chamadas de LIPO. Essas lipases possuem a capacidade de resistir a condições ácidas e apresentam uma homologia baixa (<20\%) quando comparada com lipases neutras. LIPA catalisa a deacetilacão dos ésters de colesterol e TAG de lipoproteínas lisossomais de baixa densidade (LDLs), um processo essencial de catabolismo de lipídeos intracelulares. LG está envolvida no metabolismo de TAG da dieta em condições ácidas; é sintetizada pelas células principais presentes na mucosa fúndica do estômago. As lipases representadas pelos genes LIPK, LIPM e LIPN expressas na epiderme parecem apresentar um papel específico no último passo da diferenciação de queratinócitos (HOLMES; COX; VANDEBERG, 2010).

A estrutura da LP humana determinada em 1990 mostrou uma cadeia polipeptídica que é dividida em dois domínios: o domínio N-teminal e o C-terminal. O domínio N-terminal é composto por número maior de resíduos de aminoácidos 1335, porção que pertence ao grupo estrutural das $\alpha / \beta$ hidrolases, e contém o sítio ativo com a tríade catalítica. Nesse domínio encontramos uma loop de superfície denominado "lid" (domínio tampa), definido por uma ponte dissulfeto entre a Cys238 e a Cys262 composta pelos resíduos 237-261, que cobre o sítio ativo da enzima. Esse domínio é estabilizado pela ligação a alça $\beta 5$ (resíduos 75-84) e a alça $\beta 9$ (resíduos 203-223). O domínio C-terminal (336-449), é uma estrutura composta por duas camadas de folhas $\beta$. Esse domínio é importante para a ligação da lipase pancreática de mamíferos ao seu cofator chamado colipase (LOWE, 2002; WINKLER; D'ARCY; HUNZIKER, 1990).

O acesso a Ser presente no sítio ativo da enzima depende da abertura do domínio tampa. A chamada conformação aberta permite a ligação enzima substrato com consequente hidrólise. Existem fatores que favorecem a conformação aberta, a ativação interfacial que está relacionada com presença de micelas e a ligação da colipase ao domínio PLAT presente na região C-terminal. Na presença de micelas, o domínio tampa e a alça $\beta 5$ sofrem uma reorganização estrutural, o domínio tampa se abre $29 \AA$ em um movimento de dobradiça para longe do sítio ativo o que faz com que a alça $\beta 5$ também se dobre distanciando do sítio catalítico. A posição da alça $\beta 9$ permanece a mesma nesse processo. Juntos esses movimentos abrem o sítio catalítico e reconfiguram a região para criar o bolso oxiânion, uma região eletrofílica formada pelos resíduos Phe78 e Leu154 que estabiliza o estado de transição intermediário. 
Uma segunda consequência do movimento da tampa e da alça $\beta 5$ é a criação de um platô hidrofóbico pela exposição da superfície hidrofóbica. Esta reorganização está relacionada com a ligação a uma outra proteína chamada colipase. A colipase se liga ao domínio C-terminal da enzima quando na presença de micelas, favorecendo assim a sua interação do domínio tampa presente na região N-terminal, o que amplia a plataforma hidrofóbica. Dessa forma, a enzima entra em sua conformação aberta expondo uma ampla região hidrofóbica e os resíduos do sítio ativo, permitindo o acesso ao substrato e favorecendo a ligação (CARRIERE et al.,1998; THOMAS et al., 2005; WONG; SCHOTZ, 2002) (Figura 6).

Alguns estudos relacionam a importância de estruturas hidrofóbicas como domínio tampa e a alça $\beta 9$ à especificidade da enzima frente aos substratos bem como dos resíduos de aminoácidos próximos ao sítio catalítico. Os testes foram realizados com a PRLP 2, que devido a ausência do domínio tampa, é menos especifica em relação ao substrato hidrolisando fosfolipídeos, galactolipídeos e TAG. O mutante contendo a deleção do peptídeo 207-SPILPSL-213, correspondente a alça $\beta 9$, tornou a região menos hidrofóbica gerando um prejuízo na estabilização da cadeia acil do triacilglicerol diminuindo a taxa de hidrólise de substratos com cadeias longas de ácido graxos (DRIDI et al., 2013). O aumento da rigidez de resíduos de aminoácidos próximos ao sítio catalítico da lipase podem aumentar a estabilidade cinética de lipases, aumentando as interações intermoleculares contribuindo para manutenção da atividade enzimática mesmo em altas temperaturas (KUMAR; SINGH; KAUR, 2014; XIE et al., 2014). 


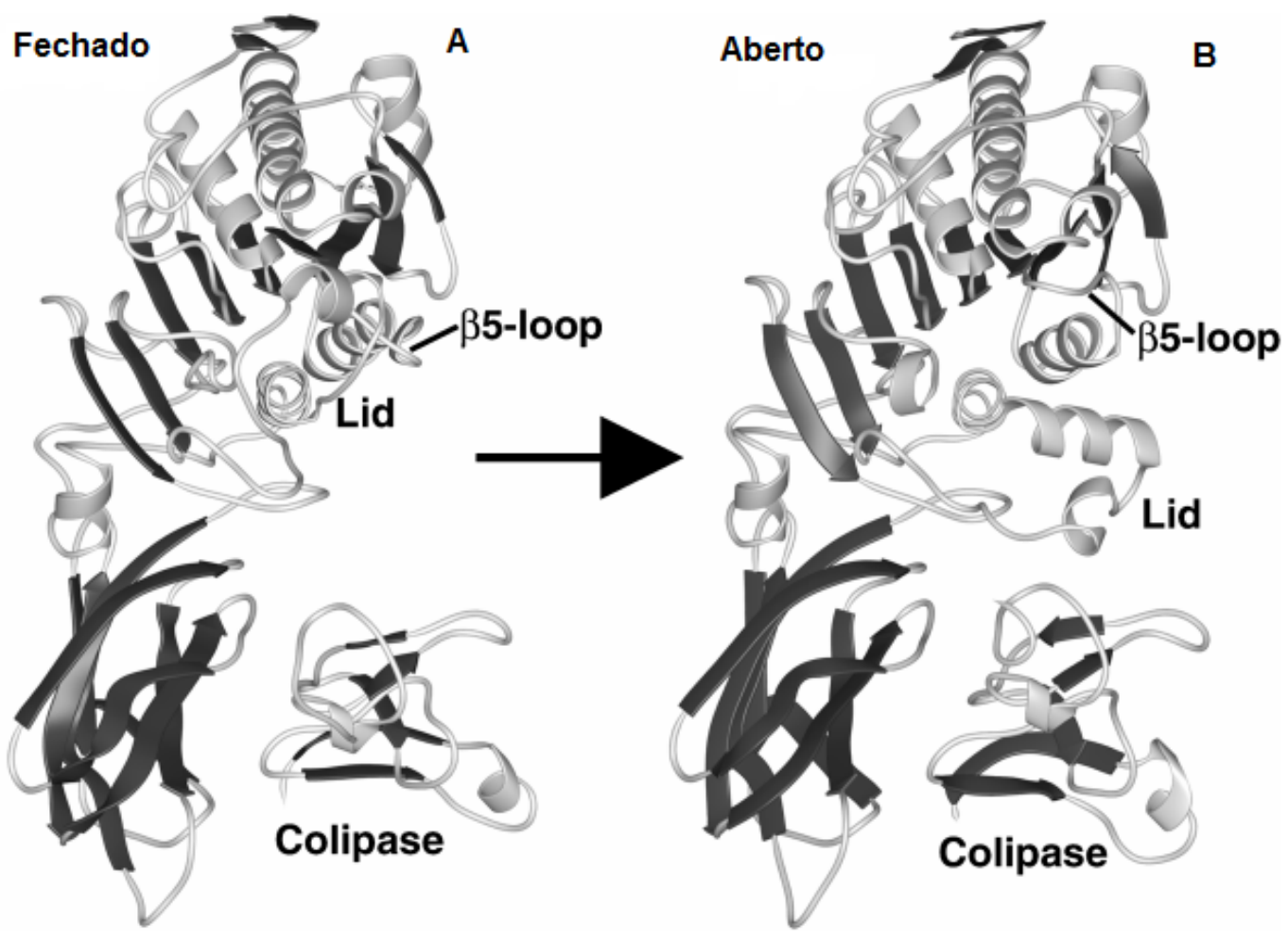

Figura 6 - Estrutura do complexo lipase pancreática humana e colipase em duas diferentes conformações: A) conformação fechada e B) conformação aberta. A porção globular, domínio N-terminal contém o domínio tampa e a alça $\beta 5$, a alça $\beta 9$ não está indicada. A colipase se liga ao domínio C-terminal. Fonte: Lowe (2002).

Estruturalmente a LG humana é composta de um domínio globular $(\approx 379$ resíduos), com dobramento pertencente a família estrutural das $\alpha / \beta$ hidrolases e é glicosilada, com 4 potenciais sítios de N-glicosilação. Essa lipase apresenta um domínio chamado "cap" (capa), que é composto por 8 a-hélices (ae1- ae8) que estão localizadas entre os resíduos 203-329. Esse domínio pode servir como um domínio tampa para a Ser174 presente no sítio ativo, restringindo o acesso ao ambiente aquoso, mas permitindo o acesso do substrato na abertura da tampa (CANAAN et al., 1999; HOLMES; COX; VANDEBERG, 2010; ROUSSEL et al., 1999) (Figura 7). 


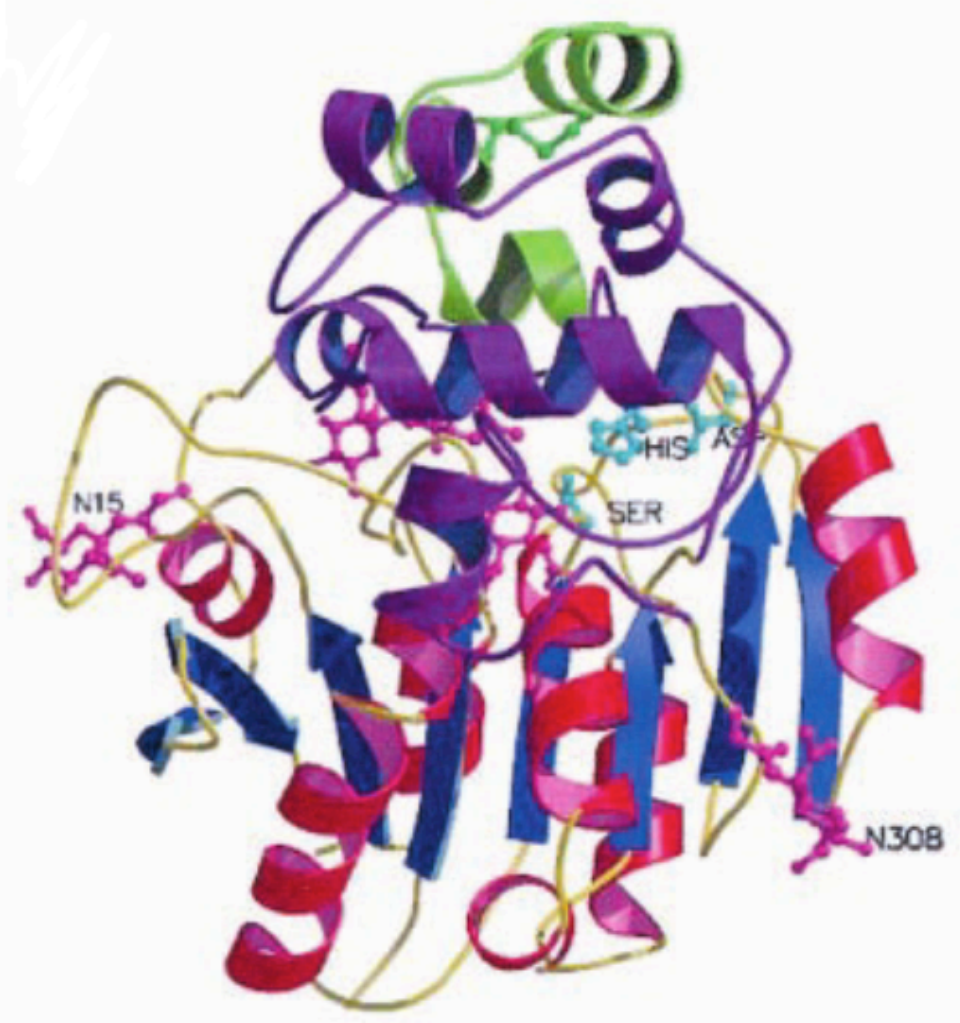

Figura 7 - Estrutura da lipase gástrica humana. O domínio capa acima do domínio central $\alpha / \beta$ hidrolase está colorido em magenta com a possível tampa colorida em verde. A cor vermelha foi utilizada Para o dobramento $\alpha / \beta$ hidrolase, as cores utilizadas foram hélices (vermelho), fitas (azul), voltas e Randon coil (amarelo). A tríade catálitica, Ser-153, His-353 e Asp-324, a ponte dissulfeto e os açúcares ligados a Asn estão mostrados na forma de bola e palito. Fonte: ROUSSEL et al. (1999).

Observamos nas lipases bem caracterizadas bioquimicamente e estruturalmente de mamíferos, que pequenas mudanças na composição de aminoácidos podem acarretar em importantes modificações estruturais alterando a eficiência de catálise e a especificidade da enzima. As lipases de insetos possuem tanto uma composição de aminoácidos distinta, quanto uma diferença de tamanho geral e de regiões ligadas a interação com o substrato. $O$ estudo de lipases de insetos pode se mostrar bastante útil para uma melhor compreensão dessa classe de enzimas. 


\subsection{Lipases em artrópodes}

Assim como em mamíferos, as lipases são fundamentais para a fisiologia dos artrópodes. A principal forma de armazenamento de ácidos graxos em insetos são os TAGs (ARRESE et al., 2001), sendo os ácidos graxos poli-insaturados lipídeos essenciais para muitos insetos (CANAVOSO et al., 2001). Após a alimentação os TAGs são hidrolisados no lúmen do intestino médio, os produtos da digestão são absorvidos e utilizados para a síntese de lipídeos como TAGs, diacilgliceróis (DAGs) e fosfolipídios (FP) (CANAVOSO; FREDE; RUBIOLO, 2004).

Existe atualmente um número crescente de trabalhos descrevendo as lipases encontradas no sistema digestório de artrópodes. No entanto, esse número ainda é pequeno quando comparado com os estudos de lipases encontradas em vertebrados. Algumas lipases digestivas presentes em artrópodes tiveram suas atividades medidas em homogeneizados brutos e algumas delas foram caracterizadas bioquimicamente (Tabela 1). Algumas lipases foram isoladas após sua identificação no sistema digestório (Tabela 2). 
Tabela 1 - Espécies de artrópodes que tiveram suas lipases digestivas caracterizadas bioquimicamente. Os parâmetros bioquímicos foram obtidos a partir de homogeneizados brutos.

\begin{tabular}{|c|c|}
\hline Animal & Referência \\
\hline Homarus americanus (Malacostraca: & BROCKENHOFF; HOYLE; \\
\hline Decapoda) & HWANG, 1970 \\
\hline Locusta migratória (Insecta: Orthoptera) & WEINTRAUB; TIETZ, 1973 \\
\hline Aedes aegypti (Insecta: Diptera) & GEERING; FREYVOGEL, 1975 \\
\hline Periplaneta americana (Insecta: Blattaria) & $\begin{array}{c}\text { BOLLADE; PARIS; MOULINS, } \\
\text { 1970; HOFFMAN; DOWNER, } \\
1979\end{array}$ \\
\hline Manduca sexta (Insecta: Lepidoptera) & TSUSHIDA; WELLS, 1988 \\
\hline Drosophila melanogaster (Insecta: Diptera) & SMITH et al., 1994 \\
\hline Spilosoma obliqua (Insecta: Lepidoptera) & ANWAR; SALEEMUDDIN, 1997 \\
\hline Lymantria díspar (Insecta: Lepidoptera) & MRDAKOVIC et al., 2008 \\
\hline Epiphyas postvittana (Insecta: Lepidoptera) & CHRISTELLER et al., 2010 \\
\hline Hermetia illucens (Insecta: Diptera) & KIM et al., 2011 \\
\hline Neohelice granulata (Malacostraca; Decapoda) & $\begin{array}{c}\text { PINONI; IRIBARNE; LÓPEZ } \\
\text { MAÑANES, } 2011\end{array}$ \\
\hline Hemimelaena flaviventris (Insecta: Plecoptera) & DE FIGUEROA et al., 2011 \\
\hline Isoperla morenica (Insecta: Plecoptera) & DE FIGUEROA et al., 2011 \\
\hline Perla bipunctata (Insecta: Plecoptera) & $\begin{array}{l}\text { LÓPEZ-RODRÍGUEZ et al., } \\
2012\end{array}$ \\
\hline Dinocras cephalotes (Insecta: Plecoptera) & $\begin{array}{l}\text { LÓPEZ-RODRÍGUEZ et al., } \\
2012\end{array}$ \\
\hline Galleria mellonella (Insecta: Lepidoptera) & ALIPOUR et al., 2013 \\
\hline Solenopsis invicta (Insecta: Hymenoptera) & LI; ZENG, 2013 \\
\hline Gryllus bimaculatus (Insecta: Orthoptera) & $\begin{array}{c}\text { WEIDLICH; HOFFMANN; } \\
\text { WOODRING, } 2015\end{array}$ \\
\hline
\end{tabular}


Tabela 2 - Espécies de artrópodes que tiveram suas lipases digestivas detectadas e isoladas.

\begin{tabular}{cc}
\hline Animal & Referência \\
\hline Periplaneta americana (Insecta: & MALE; STOREY, 1981 \\
Blattaria) & \\
\hline Locusta migratoria (Insecta: Orthoptera) & MALE; STOREY, 1981 \\
\hline Bombyx mori (Insecta: Lepidoptera) & PONNUVEL et al., 2003 \\
\hline Carcinus mediterraneus (Malacostraca: & CHERIF et al., 2007 \\
Decapoda) & \\
\hline Litopenaeus vannamei (Malacostraca: & RIVERA-PÉREZ; GARCÍA-CARREÑO; \\
Decapoda) & SABOROWSKI, 2010 \\
\hline Pieris brassicae (Insecta: Lepidoptera) & ZIBAEE, 2012
\end{tabular}

Em nosso laboratório foram medidas e caracterizadas as lipases de Tityus serrulatus (Arachnida: Scorpiones), Nephilingis cruentata (Arachnida: Araneae), Periplaneta americana (Insecta: Blattaria), Diatraea saccharalis (Insecta: Lepidoptera) e Spodoptera frugiperda (Insecta: Lepidoptera) (FILIETAZ; LOPES, 2010), Ae. aegypti (Insecta: Diptera) e Amblyomma cajennense (Arachnida: Ixodida) (FILIETAZ, 2011).

As análises realizadas para as lipases de Ae. aegypti, fase larval e adulto, mostraram que as lipases desses animais hidrolisam com maior eficiência os substratos de cadeia curta butirato (4C) e heptanoato (7C) (FILIETAZ, 2011). A mesma preferencia foi observada para as lipases de Scorpio maurus (ZOUARI et al., 2005), das mariposas Lymantria dispar (MRDAKOVIC et al., 2008) e Epiphyas postvittana (CHRISTELLER et al., 2010). Essas enzimas do mosquito não são ativadas pela presença de cálcio, apresentam pH ótimo na faixa de 8,5 a 9,0 (Filietaz, 2011). Valores semelhantes foram observados em outras lipases digestivas de insetos como as de Lymantria dispar (8,2) (MRDAKOVIC et al., 2008), Scorpio maurus $(9,0)$ (ZOUARI et al., 2007) e Rhodnius prolixus $(7,0-7,5)$ (GRILLO; MAJEROWICZ; GONDIM, 2007). A estabilidade ao $\mathrm{pH}$ é distinto entre a lipase da fase larval $(6,0$ a 12) e da fase adulta $(3,0$ a 10) e são resistentes a altas 
temperaturas, em larvas $\left(\mathrm{t}_{1 / 2}\right.$ a $60{ }^{\circ} \mathrm{C}=42$ minutos) e em adultos $\left(\mathrm{t}_{1 / 2}\right.$ a $55{ }^{\circ} \mathrm{C}=46$ minutos) (FILIETAZ, 2011).

Os dados encontrados nas análises bioquímicas apontavam para a presença de enzimas com propriedades distintas nas duas fases de desenvolvimento do mosquito Ae. aegypti. A disponibilidade do genoma desta espécie favoreceu o início de análises baseadas em sequências (NENE et al., 2007).

Com o advento dos sequenciamentos de nova geração houve um aumento do número disponível de genomas e transcriptomas. O barateamento dessa tecnologia estimulou o início de novos projetos, envolvendo diversas espécies de insetos. Atualmente, os genomas de pelo menos 138 espécies de insetos foram sequenciados e depositados em bancos de dados públicos, esses genomas bem como as sequências provenientes de transcriptomas de pelo menos 79 espécies, foram coletados e disponibilizados em um banco de dados chamado InsectBase (YIN et al., 2016). O fácil acesso a esse grande número de sequências tem permitido a identificação de proteínas, de sua localização e comparação com proteínas de outras espécies.

Desta forma, verificou-se que as lipases em insetos fazem parte de famílias multigênicas. A comparação das sequências das lipases de artrópodes com lipases de mamíferos bem caracterizadas bioquimicamente e estruturalmente como LP, PRLP2 e LG, permitem observar suas diferenças estruturais e inferir possíveis especificidades. Observações empíricas baseadas nessas comparações evidenciam a relação das lipases de artrópodes com o grupo estrutural das $\alpha / \beta$ hidrolases, podendo portanto serem agrupadas em uma das 6 famílias (seção 1.4). A presença da tríade catalítica conservada e a ausência da região de ligação a colipase além da ausência de identificação da própria colipase, apontam a presença de atividade catalítica e independência de cofatores.

As análises dos genes de lipase realizados em animais holometábolos revelaram, que para esses animais, as famílias mais numerosas são a das lipases neutras e ácidas. Além disso, demonstrou que algumas lipases neutras de insetos apresentam diminuição do domínio tampa e da região das alças $\beta 5$ e $\beta 9$ indicando que a ligação das lipases neutras de insetos aos TAGs seja diferente da encontrada em mamíferos de forma que esses domínios não sejam fundamentais nesse processo (HORNE; HARITOS; OAKENSHOTT, 2009). 
Para os genes de lipases de Epiphyas postvittana, além das diferenças previamente descritas para as lipases de insetos, observou-se diferença no número dos pares de cisteína que estão envolvidos na formação de pontes dissulfeto. Os resultados encontrados nesse trabalho sugerem que essas enzimas talvez não hidrolisem majoritariamente TAGs, mas hidrolisem, por exemplo, galactolipídeos e fosfolipídeos (CHRISTELLER et al., 2010). Essa suposição está baseada na comparação de sequências, sendo as lipases neutras desses animais bastante similares as PRLP2, que são conhecidas por atuarem na hidrólise de fosfolipídeos, galactolipídeos e TAGs (CARRIERE at al., 1998). Portanto, os insetos que têm sua alimentação baseada em tecidos de planta ricos em fosfolipídeos e galactolipídeos teriam suas lipases neutras agindo sobre esses substratos.

Os autores sugerem que a hidrólise de TAGs seria catalisada pelas lipases ácidas, as quais apresentam todos os domínios conservados em relação às lipase gástrica humana (CHRISTELLER et al., 2010). Seis espécies de Lepidoptera com diferentes hábitos alimentares (folivoras, granívoras, carnívoras e queratinofagas) tiveram suas atividades e expressão de lipases avaliadas. Apesar das dietas parecerem influenciar a expressão das lipases, aparentemente estas variações regulam a expressão das lipases neutras, mas não alteram a expressão das lipases ácidas como seria esperado em dietas ricas em TAG. Portanto, esses dados não permitem afirmar que a lipase ácida atuaria exclusivamente na hidrólise de TAGs, mas sim que a lipase neutra aparentemente está envolvida na digestão de diferentes espécies lipídicas em Lepidoptera sendo semelhantes a PRLP2 de mamíferos (CHRISTELLER; AMARA; CARRIERE, 2011).

Faltam ainda evidências bioquímicas para identificar claramente o papel destas duas famílias de lipases em insetos herbívoros e também em hematófagos.

Além das aparentes diferenças na especificidade, as lipases digestivas presentes nos artrópodes estudados podem apresentar regulação de sua expressão. A regulação pode estar relacionada com transformações naturais no desenvolvimento do animal como: alimentação, muda ou reprodução mas também a fatores ambientais como presença de resíduos químicos e biológicos como patógenos. Muitos desses fatores foram estudados e revelam um aspecto intrigante da ação das lipases digestivas nesses animais e como sua função pode ir além da aquisição e mobilização de lipídeos (PONNUVEL et al., 2003; ARAÚJO et al., 2008; LV et al., 2015). 
O intestino é uma das mais importante interfaces de contato com o ambiente em insetos e está sujeita a interferências que podem afetar o perfil de expressão gênica, alguns exemplos estão descritos a seguir.

A exposição continuada a inseticidas pode alterar o perfil de expressão gênica, sendo um mecanismo conhecido de indução da resistência chamado de resistência metabólica. Esse efeito pode ser observado em besouros Sitophilus zeamais resistentes a piretróides que apresentaram um aumento na atividade de lipase e trealase (ARAÚJO et al., 2008).

O mosquito Culex pipiens pallens resistente ao piretróide deltametrina apresentou 1826 genes diferencialmente expressos, apresentando tanto aumento quanto redução da expressão de genes específicos. Dentre os genes diferencialmente expressos 19 pertencem a família das lipases, sendo que 18 apresentam expressão aumentada (LV et al., 2015). Mosquitos Culex pipiens quinquefasciatus resistentes ao inseticida organofosforado "paration" apresentaram a expressão aumentada em 2,9 vezes em uma de suas lipases (WANG et al., 2014).

No mosquito Ae. aegypti as alterações nos níveis de expressão foram verificadas em três grupos de larvas de quarto estádio que foram previamente selecionadas para resistência contra inseticidas de três diferentes classes: piretróides, neonicotinóides e carbamatos. Dentre genes envolvidos em diferentes funções foi possível observar a presença de duas lipases que tiveram seus níveis de expressão aumentados. A lipase AAEL006880 apenas para mosquitos resistentes a imidacloprida e o precursor de lipase 1 AAEL012344 em todos os mosquitos resistentes testados (DAVID et al., 2014).

A regulação dos níveis de expressão de enzimas envolvidas em alta mobilização de energia, como as lipases, possivelmente está ligada a necessidade da manutenção ativa dos mecanismos de resistência. Não se sabe entretanto a localização exata dessas lipases e em que processos específicos elas estariam envolvidas.

Estímulos gerados pela alimentação também podem alterar a expressão de genes. Larvas da lagarta Trichoplusia ni mostraram que o tipo de alimentação influencia diretamente a expressão de lipase no intestino médio. O número de lipases expressas é menor na alimentação com plantas selvagens do que quando comparada com a alimentação com plantas mutadas. A mutação consiste na deleção do gene COI1. A ausência dessa proteína elimina a resposta de defesa da 
planta relacionada com o jasmonato (JA), esse hormônio de sinalização está envolvido em diversos processos na planta em particular na expressão de proteínas que atuam na defesa contra herbivoria (HERDE; HOWE, 2014).

Larvas de Bombyx mori alimentadas com folhas expostas ao inseticida organofosforado Phoxim ${ }^{\circledR}$ (Bayer S.A., São Paulo, SP., Brasil) apresentaram regulação da expressão de 52 genes envolvidos em digestão e absorção. A expressão de uma lipase envolvida em digestão foi significantemente suprimida após a exposição ao inseticida (YU et al., 2013).

A mosca Drosophila melanogaster mostrou aumento da expressão de duas lipases ácidas digestivas (Lip 3 e CG6113) quando privada de alimento. Quando as larvas foram alimentadas com açúcar duas lipases neutras, CG6271, CG6277 que são encontradas na porção anterior do intestino médio apresentaram redução em seus níveis de expressão, e as ácidas citadas apresentaram níveis normais (ZINKE et al., 2002). Uma terceira lipase neutra (CG6295) encontrada no sistema digestório se mostrou regulada pela presença de lipídeos na dieta e tem sua expressão ligada a um fator de transcrição que regula a síntese de lipídeos (KUNTE et al., 2006). Os resultados desses trabalhos parecem indicar que a regulação da expressão das lipases envolvidas na digestão depende da composição do alimento.

A lipase Bmlipase-1 expressa no intestino médio da lagarta Bombyx mori foi isolada a partir do suco digestivo do animal e apresentou atividade anti-viral contra o vírus nucleopoliedrovirus (BmNPV) (PONNUVEL et al., 2003). A redução da mortalidade provocada pela infecção por BmNPV foi observada em lagartas transgênicas que superexpressam a Bmlipase-1, o que sugere seu efeito na inibição da proliferação viral. Foi também observado que o aumento no nível dos transcritos de Bmlipase-1 foi induzido pela infecção por BmNPV, o que é um indício da atuação dessa enzima no processo infeccioso e não somente na digestão (JIANG et al., 2012; XU et al, 2015).

Diferente do que foi observado para a infecção viral em Bombyx mori a infecção pela bactéria Bacillus thuringiensis em larvas de Lymantria dispar resultou em uma forte inibição da expressão da lipase neutra bem como de outras enzimas e genes envolvidos na digestão (SPARKS et al., 2013).

A análise para identificação das lipases digestivas do mosquito Ae. aegypti foi realizada no nosso grupo (FILIETAZ, 2011). Foi iniciada por uma busca nominal no banco de dados VectorBase onde estão disponíveis as sequências provenientes do 
genoma do animal. As 72 sequências anotadas como lipase foram obtidas no formato fasta no banco de dados do NCBI através de seus números de acesso, todo o processo de seleção pode ser observado na figura 8.

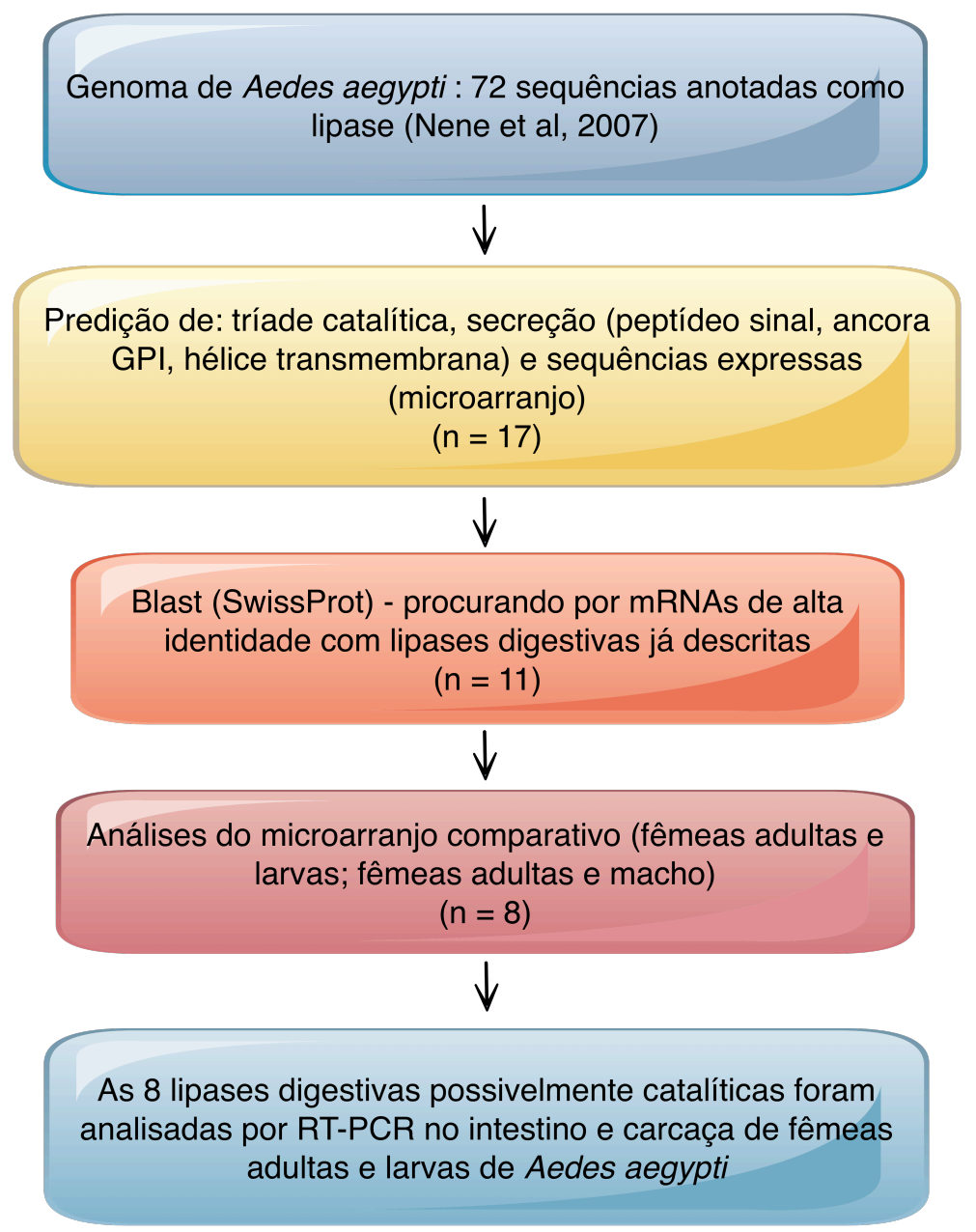

Figura 8 - Critério de seleção para as sequências anotadas como lipase provenientes do genoma do mosquito Ae. aegypti.

As lipases cataliticamente ativas foram selecionadas por alinhamento com a LP humana (NP_000927), pela presença da triáde catalítica. Das 72 sequências analisadas, 35 possuíam os resíduos da tríade catalítica: Ser152, Asp176 e His263, as demais sequências foram eliminadas.

Para identificar lipases possivelmente secretadas, estas 35 sequências foram analisadas através de ferramentas de predição do Expasy (SWISS INSTITUTE OF BIOINFORMATICS, 2016). Foram identificadas a presença de peptídeo sinal (SignallP 3,0 Server) ou âncora GPI (big-PI Predictor) e ausência de alça transmembrana (SOSUI), resultando em 22 sequências selecionadas. Nene et al. 
(2007) realizaram estudos de expressão diferencial observando ESTs, MPSS (Massive Parallel signature sequencing) e microarranjo em larvas, fêmeas e machos adultos. Baseado nessas informações selecionamos sequências de lipases expressas, resultando em 17 sequências.

As 17 sequências foram alinhadas contra o banco de dados de proteínas SwissProt (UNIPROT, 2016) por Blastp (NACIONAL CENTER FOR BIOTECHNOLOGY INFORMATION, 2016a), as sequências que apresentaram alta identidade com lipases digestivas de insetos foram selecionadas, reduzindo o nosso número para 11. Os resultados encontrados no microarranjo nos permitiram observar quais genes eram expressos em larvas e fêmeas adultas e quais foram expressos em machos e fêmeas adultas, sendo que as sequências correspondentes a lipases expressas somente em machos foram excluídas. Dessa forma, foram selecionadas 8 sequências que foram analisadas por RT-PCR semi-quantitativo. Foi possível observar amplificação de 4 das sequências testadas, a lipase AAEL002911 apresentou amplificação na carcaça e intestino na fase larval e adulta, a lipase AAEL007044 apresentou amplificação somente em carcaças de animais adultos, as lipases que apresentaram amplificação somente no intestino médio foram: AAEL007055 (L-Aa7055) encontrada no intestino de fêmeas adultas e AAEL007051 (L-Aa7051) encontrada no intestino de larvas (Figura 9).

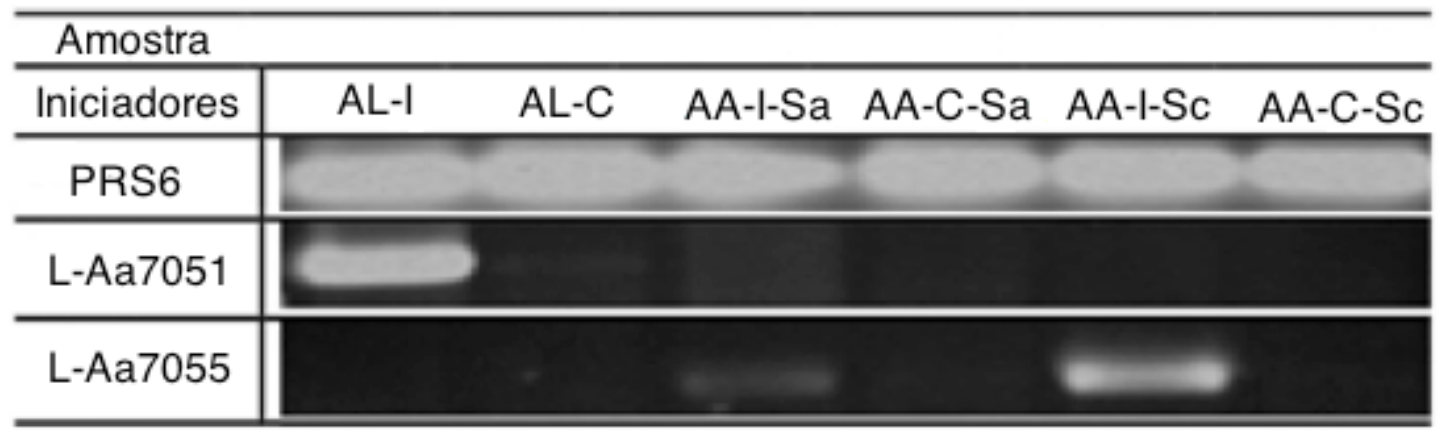

Figura 9 - RT-PCR semi-quantitativo mostra a transcrição de mRNAs dos 2 genes selecionados que amplificam lipases no intestino. A transcrição foi testada nos seguintes tecidos do mosquito Ae. aegypti: intestino médio de larvas L4 $(A L-I)$, em carcaças de larvas $L 4(A L-C)$, no intestino médio de fêmeas adultas alimentadas com sangue (AA-I-Sa) e na carcaça das mesmas (AA-C$\mathrm{Sa}$ ), no intestino médio de fêmeas adultas alimentadas com sacarose (AA-ISc) e em carcaças das mesmas (AA-C-Sc).

Sendo o RT-PCR uma metodologia semi-quantitativa, as evidências encontradas nesse experimento não permitiam afirmar que as lipases encontradas 
em larvas e em animais adultos são expressas exclusivamente no intestino. Da mesma forma, não foi possível determinar se a aparente expressão diferencial, encontrada em intestinos de fêmeas adultas alimentadas com sangue e com sacarose, realmente existia. Além disso, não conhecíamos os efeitos de infecção por $P$. gallinaceum e DENV2 sobre a expressão de lipases digestivas.

O processo de digestão de lipídeos no mosquito Ae. aegypti ainda não foi bem caracterizado. A caracterização das lipases do mosquito pode nos ajudar a compreender a sua importância fisiológica, em aspectos como o desenvolvimento do animal e seu comportamento durante a infecção. $O$ estudo cinético dessas enzimas pode nos ajudar a compreender melhor o funcionamento dessa classe de enzimas, que é estruturalmente distinta das lipases neutras humanas. A independência de cofatores para seu funcionamento e sua possível inespecificidade em relação ao substrato podem se mostrar características interessantes para sua utilização em sistemas biotecnológicos. 


\section{OBJETIVOS}

Os objetivos desse trabalho foram analisar a expressão de lipases digestivas em duas fases de desenvolvimento do mosquito Ae. aegypti e em diferentes dietas, incluindo alimentações em hospedeiros infectados por Plasmodium galinaceum e por vírus dengue. Comparar as sequências das lipases do mosquito Ae. aegypti com sequências de outras lipases para verificação de estruturas correlacionadas à especificidade destas enzimas. Além disso, identificar diferenças de especificidade destas enzimas após expressão heteróloga das lipases identificadas como digestivas em Ae. aegypti.

\subsection{Objetivos específicos}

1. Confirmar por qPCR a existência de duas lipases digestivas distintas, uma presente na fase larval e outra na fase adulta do mosquito Ae. aegypti.

2. Clonar e expressar em sistema heterólogo as lipases digestivas neutras já caracterizadas como lipases expressas nas fases larval e adulta do mosquito Ae. aegypti.

3. Medir a atividade destas lipases sobre diversos substratos através de ensaios de titulação.

4. Fazer análises in silico das lipases descritas no genoma de Ae. aegypti.

5. Analisar a expressão destas lipases digestivas através de qPCR em animais infectados e não infectados por vírus dengue (DENV 2) e Plasmodium gallinaceum. 


\section{MATERIAIS E MÉTODOS}

Toda metodologia, os materiais e equipamentos utilizados estão descritos nos itens a seguir.

\subsection{Manutenção e dissecção dos mosquitos Ae. aegypti}

As larvas e fêmeas adultas do mosquito Ae. aegypti (cepa Higgs White-eyes e Red) foram fornecidos pela Dra. Margareth de Lara Capurro-Guimarães do laboratório de mosquitos geneticamente modificados do Instituto de Ciências Biomédicas, Universidade de São Paulo.

A temperatura do insetário foi mantida a $27{ }^{\circ} \mathrm{C}$ com umidade relativa de $80 \%$ e fotoperíodo de luz/escuro de 16/8 horas. Após a eclosão dos ovos, as larvas de Ae. aegypti foram alimentadas com ração de peixe moída TetraMin (Tetra, Melle, Osnabrück, Alemanha) até atingirem o quarto estádio de desenvolvimento (L4). A ração é composta por grânulos enriquecidos com nutrientes e vitamina $C$, contendo em sua composição básica ácido cítrico, arroz integral, farelo de aveia, gérmen de trigo, farelo de soja, farinha de algas marinhas, de camarão e de peixe, levedura inativada e outros.

As larvas de estádio 4 foram isoladas em uma placa de Petri e colocadas sobre o gelo para anestesiar os animais, os quais foram submetidos a dissecção sob estereomicroscópio em solução $\mathrm{NaCl} 0,9 \%$ gelada permitindo assim o isolamento dos intestinos médios.

O segundo grupo de larvas, não utilizadas para a dissecção, permaneceram até o estádio de pupa em recipientes plásticos. As pupas foram colocadas em copos de plástico vedados por filó para a emersão dos adultos que se alimentam em solução de sacarose $10 \%$ at libitum. Os animais utilizados em experimentos são mantidos por 5 dias em copos de plástico na proporção de 3 fêmeas para cada macho, nesse período ocorre o cruzamento.. As fêmeas de 7 a 9 dias de vida são submetidas ao repasto sanguíneo, para que a alimentação ocorra de maneira adequada. A sacarose $10 \%$, na qual os animais são mantidos após a emersão, é retirada 24 horas antes do repasto. Após o período do repasto a solução de sacarose $10 \%$ é reposta até o período de coleta e dissecção.

As fêmeas adultas do mosquito Ae. aegypti foram dissecadas 15 horas após o repasto sanguíneo para a obtenção do intestino médio, dado que nesse ponto é 
descrito o pico de atividade enzimática da lipase (GEERING; FREYVOGEL, 1975). As fêmeas adultas alimentadas foram anestesiadas com dióxido de carbono $\left(\mathrm{CO}_{2}\right)$, mantidas no gelo em uma placa de Petri e dissecadas sob estereomicroscópio em solução $\mathrm{NaCl}$ 0,9\% gelada permitindo assim o isolamento dos intestinos médios. As amostras foram mantidas a $-20{ }^{\circ} \mathrm{C}$ até a sua utilização.

Cada lote utilizado para medida de atividade enzimática continha aproximadamente 100 animais. Os intestinos de Ae. aegypti larva e adulto foram homogeneizados em água ultrafiltrada (MilliQ) (Millipore, Billerica, Massachusetts, United States) gelada utilizando um homogeinizador do tipo Potter-Elvehjem. Os homogeneizados de intestino médio de larvas e fêmeas adultas de Ae. aegypti foram utilizados como fonte de atividade enzimática.

Os lotes utilizados para extração de RNA continham o intestino médio de 15 animais, que foram dissecados e imediatamente armazenados a $-80{ }^{\circ} \mathrm{C}$ em microtubos autoclavados até a homogeinização em TRIzolß (Invitrogen Life Technologies, Carlsbad, California, United States). O tempo de dissecção, após a alimentação, variou de acordo com o desenho do experimento. Todo material utilizado para a dissecção foi esterilizado, em forno a $150{ }^{\circ} \mathrm{C}$ por 4 horas ou por calor úmido em autoclave.

\subsection{Ensaios enzimáticos e quantificação de proteína}

Todas as metodologias utilizadas para ensaios enzimáticos, bem como para quantificação de proteína em amostras utilizadas estão descritas a seguir. O material na qual a metodologia foi aplicada, também está indicado.

\subsubsection{Substratos fluorimétricos para detecção de lipase}

Dentre as diversas metodologias descritas na literatura para a quantificação da atividade de lipase, optamos pela utilização de fluorimetria, colorimetria e titulação (HASAN; SHAH; HAMEED, 2009).

Foi feita a padronização do ensaio de lipase utilizando 4-metilumbeliferil Oleato (Oleato - 18 carbonos com uma insaturação no carbono 9 MUO) (JACKS; KIRCHER, 1967). Uma solução estoque de MUO 2,0 mM foi preparada em acetonitrila. Esta solução foi diluída 10 vezes em tampão Tris-HCL $0,1 \mathrm{M} \mathrm{pH} \mathrm{8,5}$ contendo E-64 $10 \mu \mathrm{M}$ e TRITON X-100 0,1\% antes de cada ensaio (mistura padrão). 
Para realização dos testes de especificidade em relação ao substrato além de MUO também foram utilizados: 4-Metilumbeliferil Butirato (Butirato - 4 carbonos) e 4-Metilumbeliferil Heptanoato (Heptanoato - 7 carbonos), os quais apresentam distinção no comprimento da cadeia carbônica e na presença ou ausência de insaturações (Figura 10). Os diferentes substratos também foram utilizados mantendo as condições da mistura padrão. Para verificar a presença da lipase digestiva, o homogeneizado dos animais foi incubado na presença dos substratos em condições de $\mathrm{pH}$ adequadas para a atividade da enzima e com os controles (branco de substrato e branco de enzima).

A hidrólise enzimática destes substratos leva a produção de metilumbeliferona, que foi medida em espectrofluorímetro Gemini (Molecular Devices, Sunnyvale, California, United States) com comprimento de onda de excitação de $360 \mathrm{~nm}$ e de emissão de $460 \mathrm{~nm}$.

Uma curva padrão utilizando metilumbeliferona em $\mathrm{pH}$ idêntico ao de ensaio foi utilizada, o que permitiu o cálculo da atividade enzimática em $\mathrm{U}$, sendo que um $\mathrm{U}$ equivale a $1,0 \mu \mathrm{mol}$ de produto formado por minuto.

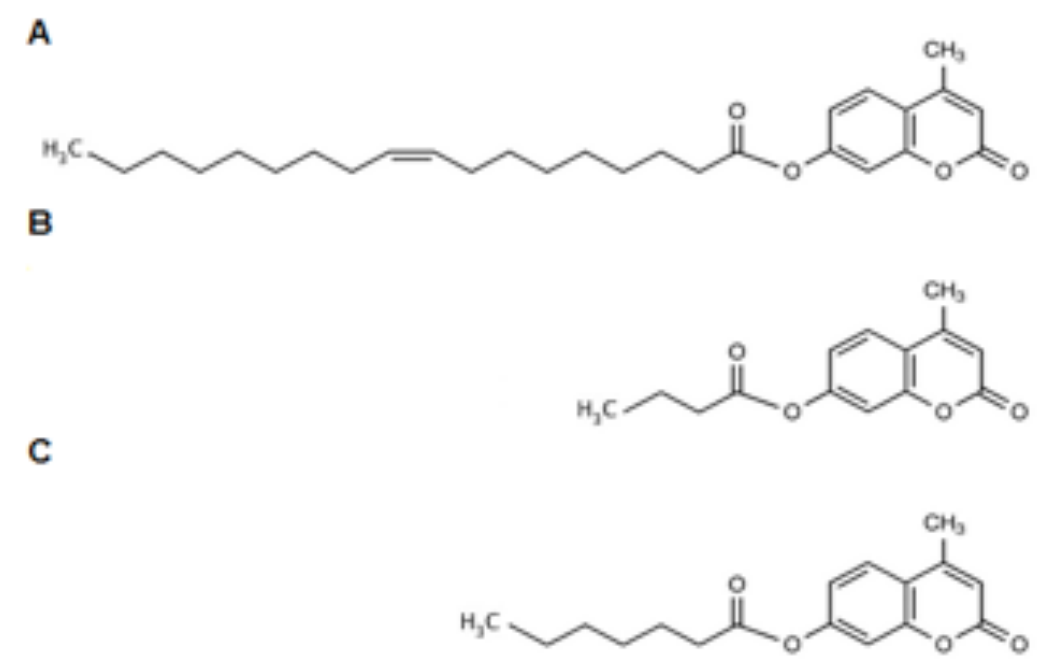

Figura 10 - Substratos derivados de 4-metilumbeliferona, utilizados para a medida da atividade enzimática de lipase. A) 4-Metilumbeliferil Oleato, 18 carbonos com uma insaturação no carbono 9; B) 4-Metilumbeliferil Butirato, 4 carbonos; C) 4-Metilumbeliferil Heptanoato, 7 carbonos. Fonte: Chemical Book, 2008. 


\subsubsection{Substrato colorimétrico para detecção de lipase}

Choi et al. (2003) otimizaram um ensaio para lipases descrito por Kurooka et al. (1977), utilizando 5,5'ditiobis (2-nitro benzoic acid) - DNTB, reagente de Ellman e 2,3-dimercapto-1-propanol tributirato (DMPTB) como substrato. Grupos tiol livres que são gerados pela hidrólise de DMPTB por lipases reduzem o DNTB o qual fica amarelo quando reduzido.

Este método é mais simples e mais sensível quando comparado aos métodos que utilizam titulação e são estruturalmente mais semelhantes aos TAGs do que os p-nitrofenil esteres que são comumente utilizados para ensaios colorimétricos. No entanto, a sua utilização era limitada pelas reações não específicas dos substratos do tipo tio-esteres ou do DTNB. O problema foi parcialmente resolvido pela adição de PMSF (phenylmethylsulfonyl fluoride) o qual pode suprimir a hidrólise de DMPTB por esterases não específicas. No entanto, para o ensaio de materiais brutos um erro significativo era observado em comparação com os dados obtidos pelo método de titulação.

A otimização do método de DMPTB-DTNB para microplacas consiste basicamente do uso de um branco sem DMPTB a fim de medir reações não especificas do DTNB principalmente para amostras brutas. Uma solução estoque de DTNB $40 \mathrm{mM}$ foi preparada em isobutanol. Uma solução estoque DMPTB $10 \mathrm{mM}$ foi dissolvida em tampão Tris- $\mathrm{HCl} 50 \mathrm{mM} \mathrm{pH} \mathrm{7,2} \mathrm{contendo} \mathrm{Triton} \mathrm{X-100} \mathrm{6 \% .} \mathrm{As} \mathrm{duas}$ soluções estoques foram aliquotadas e mantidas a $-20^{\circ} \mathrm{C}$ até utilização.

Uma mistura para os ensaios foi montada da seguinte maneira: 4,0 $\mu \mathrm{L}$ de DMPTB $10 \mathrm{mM}, 4,0 \mathrm{uL}$ de DTNB $40 \mathrm{mM}, 0,4 \mathrm{uL}$ de EDTA 0,2 M, 1,0 uL Triton X-100 10\%, 9,0 uL tampão Tris-HCl 1 M pH 7,5, 1,0 uL de PMSF 5 mM, 1,8 uL de E-64 1,0 mM e 158,8 uL.de água MilliQ. Os controles de enzima e substratos foram realizados em todos os ensaios.

\subsubsection{Ensaio titrimétrico para detecção de lipase}

O ensaio titrimétrico para lipase foi realizado conforme descrito por Christeller et al. (2011), sendo uma otimização do método previamente descrito por Carriere et al. (1993). O ensaio foi realizado em um volume final de $10 \mathrm{~mL}$ em um titulador T50 (Mettler-Toledo, Barueri, SP, Brasil), utilizando um eletrodo InLab® Ultra-Micro (Mettler-Toledo, Barueri, SP, Brasil). 
$\mathrm{O}$ pH das misturas foi mantido em 8,5 utilizando $\mathrm{NaOH}$ 0,1 $\mathrm{M}$ como solução titulante. Uma unidade $(U)$ é equivalente a $1 \mu \mathrm{mol}$ de ácido graxo titulado por $\mathrm{NaOH}$ por minuto. Após um período inicial de incubação onde o pH da solução é ajustado para 8,5, a reação é iniciada coma a adição da fonte da enzima (homogeneizado ou porção solúvel contendo lipase recombinante), a quantidade da fonte da enzima pode variar de 250 a $1000 \mu \mathrm{L}$. Os testes realizados em homogeneizados do mosquito Ae. aegypti utilizaram grandes volumes, mínimo de $500 \mu \mathrm{L}$, sendo que um lote do homogeneizado é composto pelo intestino médio de 100 animais em $1 \mathrm{~mL}$. Para o controle da degradação espontânea do ácido graxo utilizado uma reação controle é realizada sem a adição da enzima.

A atividade de triacilglicerol lipase é determinada usando $2 \mathrm{~mL}$ de gliceril trioctanoato (Sigma Chemical Co.). A solução inicial contém Tris 0,25 mM, NaCl 135 $\mathrm{mM}$, taurodeoxicolato de sódio (NaTDC) 0,5 mM, $\mathrm{CaCl}_{2} 10 \mathrm{mM}, \mathrm{pH}$ 8,5 e 0,2 M de gliceril trioctanoato.

\subsubsection{Determinação de proteína}

A quantificação de proteína das diferentes amostras foi realizada pelo método do ácido bicinchonínico (BCA), descrito por Smith et al. (1985), utilizando ovoalbumina como padrão.

\subsection{Extração de RNA total de intestino médio, resto de corpo (carcaça) e tratamento com DNAse}

As extrações de RNA total foram realizadas de acordo com a necessidade de cada experimento, sendo geralmente intestinos ou resto de corpo (carcaça) da fase larval e adulta do mosquito Ae. aegypti. Qualquer variação do protocolo como: número de animais, presença de patógenos, tipo de alimentação e tempo da dissecção após alimentação será mencionada nos métodos do experimento. Os lotes utilizados para extração contém o material a ser analisado de 15 animais dissecados.

Os animais foram dissecados em uma solução ( $\mathrm{NaCl} 0,9 \%$ ) preparada em $\mathrm{H}_{2} \mathrm{O}-\mathrm{DEPC}$. Durante a dissecção foi possível obter o intestino médio dos animais e suas respectivas carcaças que foram armazenados em microtúbulos de 1,5 mL que estavam mergulhados em banho de gelo-seco e etanol, para o congelamento imediato, as amostras foram estocadas a $-80{ }^{\circ} \mathrm{C}$ até a sua utilização. 
Os intestinos médios e as respectivas carcaças foram homogeneizadas em com auxílio de seringas (1,0 e 2,0 mL) ou com auxílio de pistilos próprios para homogeneização em microtubos em TRIzol® (Invitrogen Life Technologies, Carlsbad, California, United States). O volume de TRIzol® utilizado variou conforme o número de tecidos homogeneizados. As carcaças individuais, utilizadas para

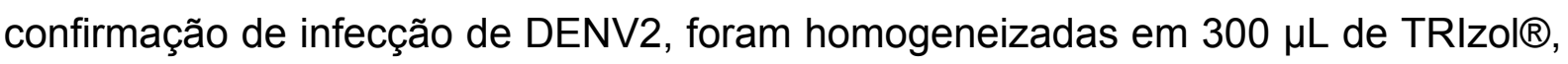
as carcaças homogeneizadas juntas (15 animais) assim como os intestinos (15 intestinos), utilizados para verificação das lipases, foram homogeneizados em $1 \mathrm{~mL}$ de TRIzol®.

O grau de pureza e a quantidade de RNA da amostra foi avaliada através de determinação da absorbância a 260 nm e 280 nm (NanoVue - GE Healthcare UK Ltd, Little Chalfont, Buckinghamshire, England).

As amostras extraídas, foram tratadas com DNase (Invitrogem Life Technologies) garantindo dessa forma a pureza do material. As amostras contendo $5 \mu \mathrm{g}$ do RNA total, foram incubadas com $1 U$ de DNase a $37^{\circ} \mathrm{C}$ por 30 minutos, seguindo-se a adição de $1 \mu \mathrm{L}$ de EDTA 25 mM e incubação a $65^{\circ} \mathrm{C}$ por 10 minutos.

\subsection{Síntese da fita de cDNA}

Para sintetizar a primeira fita de cDNA a partir do mRNA extraído foi usado o Kit "SuperScrip III First strand synthesis system for RT" (Invitrogen Life Technologies). Em todas as reações de síntese de cDNA foram utilizados $5 \mu \mathrm{g}$ do RNA total, os demais componentes e tempos de incubação foram utilizados de acordo com a recomendação do fabricante.

\subsection{Reação em cadeia com DNA polimerase em (RT-PCR)}

Para as reações de PCR utilizamos a enzima Taq DNA polimerase (Invitrogen Life Technologies), em reações de $50 \mu \mathrm{L}$ contendo oligonucleotideos $2 \mathrm{mM}$, dNTPs 10 mM, Tampão da Taq platinum DNA polimerase, $\mathrm{MgCl}_{2}$ 1,5 mM e DNA molde em concentração variável.

As reações foram realizadas em termociclador Veriti (Applied Biosystems, Carlsbad, California, E.U.A.) com desnaturação inicial por 4 minutos (RT-PCR). Em seguida foram realizados mais 35 ciclos como descrito a seguir: 30 segundos a 94 ${ }^{\circ} \mathrm{C}$, para a desnaturação da dupla fita do DNA, 60 segundos a $55{ }^{\circ} \mathrm{C}, 2$ minutos a 
$72^{\circ} \mathrm{C}$ e finalmente 10 minutos a $72^{\circ} \mathrm{C}$ para elongamento da fita complementar de DNA.

\subsection{Análise da expressão do gene de lipase AAEL007055 no intestino médio em fêmeas adultas do mosquito Ae. aegypti}

A amplificação do gene AAEL007055 foi verificada por RT-PCR no intestino médio de mosquitos em três condições: jejum, alimentação com sacarose e repasto sanguíneo.

No jejum, os animais foram mantidos sem alimentação desde que emergiram. Na alimentação com sacarose, após emergirem, os mosquitos tiveram acesso a uma solução de sacarose $10 \%$ ad libitum. Para a alimentação com sangue, foram mantidos em sacarose $10 \%$ ad libitum e a mesma foi retirada 24 horas antes do repasto sanguíneo, que foi realizado por um período de 30 minutos em camundongos.

Os animais submetidos a repasto sanguíneo foram dissecados nos seguintes intervalos de tempo: imediatamente após a alimentação (T0), 3, 6, 9, 12, 15 e 18 horas após a alimentação.

\subsection{PCR quantitativo em tempo real (qPCR)}

Os experimentos de qPCR foram realizados com a utilização do Kit ABsolute qPCR SYBR Green Mix (Thermo Fisher Scientific, Waltham, Massachusetts, E.U.A.). As análises foram realizadas em triplicata nas amostras de cDNA dos tecidos e estágios de desenvolvimento descritos acima. Em todas as corridas a expressão do gene constitutivo proteína ribossomal S7 (PRS7) (GEISER; ZHANG; WINZERLING, 2006) foi medida. Os genes de lipase utilizados para a análise foram L-Aa7055 e LAa7051, previamente identificados em fêmeas adultas e larvas, respectivamente.

Para que os dados da expressão relativa dos genes pudessem ser analisados, as eficiências de amplificação foram determinadas através de uma curva de melting. A preparação do cDNA foi diluída em diluições seriadas 1, 1/10, 1/100 e 1/1000, em cada diluição a amplificação do gene alvo foi determinada bem como do calibrador (gene constitutivo), permitindo assim a obtenção do $\Delta \mathrm{C}_{\mathrm{T}}$. Através de um plote do log da diluição de cDNA por $\Delta \mathrm{C}_{\mathrm{T}}$ foi possível observar que o valor do gene alvo e do gene referência estão próximos de zero, portanto as eficiências de 
amplificação dos genes são similares e a quantificação relativa por $\Delta \Delta \mathrm{C}_{\mathrm{T}}$ pode ser utilizada.

A otimização dos iniciadores (primers) utilizados foi realizada e teve como objetivo determinar as concentrações ideais, sendo acima de $125 \mathrm{nM}$ para LAa7051, acima de 250 nM para L-Aa7055 e acima de 250 nM para PRS7, utilizei a concentração de $250 \mathrm{nM}$ para todos os ensaios.

\subsection{Infecção dos mosquitos Ae. aegypti pelo parasita $P$. gallinaceum}

O ciclo de $P$. gallinaceum é mantido no laboratório de mosquitos geneticamente modificados do Instituto de Ciências Biomédicas - USP. Todos os experimentos de alimentação e dissecção de animais infectados foram realizados no local sob autorização da Dra. Margareth de Lara Capurro-Guimarães.

A infecção dos pintainhos (Gallus gallus domesticus) é realizada através da picada de mosquitos infectados. No sétimo dia após a infecção dos pintainhos, foram feitas lâminas de esfregaço sanguíneo corados com Giemsa, e a parasitemia determinada pela contagem do número de hemácias parasitadas/total de hemácias contadas, através de microscopia óptica com aumento 1000 vezes. Os pintainhos que apresentam alta parasitemia, ideal de 5 a 10\% das hemácias infectadas, foram anestesiados e utilizados para a infecção de mosquitos sadios através do repasto sanguíneo..

Os mosquitos são anestesiados com $\mathrm{CO}_{2}$ e mantidos no gelo para separação e eliminação das fêmeas não alimentadas. Sete dias após o repasto sanguíneo, 5 a 10 tratos digestivos foram dissecados em PBS $\left(\mathrm{NaHPO}_{4} 7 \mathrm{mM}, \mathrm{NaH}_{2} \mathrm{PO}_{4} 2 \mathrm{mM}\right.$, $\mathrm{NaCl} 140 \mathrm{mM} \mathrm{pH} \mathrm{7,0)} \mathrm{e} \mathrm{analisados} \mathrm{por} \mathrm{microscopia} \mathrm{de} \mathrm{contraste} \mathrm{de} \mathrm{fase} \mathrm{(Axio} \mathrm{Photo}$ - Zeiss) para confirmação da infecção pela contagem de oocistos (Figura 11). As fêmeas infectadas foram utilizadas para inocular pintainhos sadios ou dissecadas para obtenção de tecidos e futuras análises. 


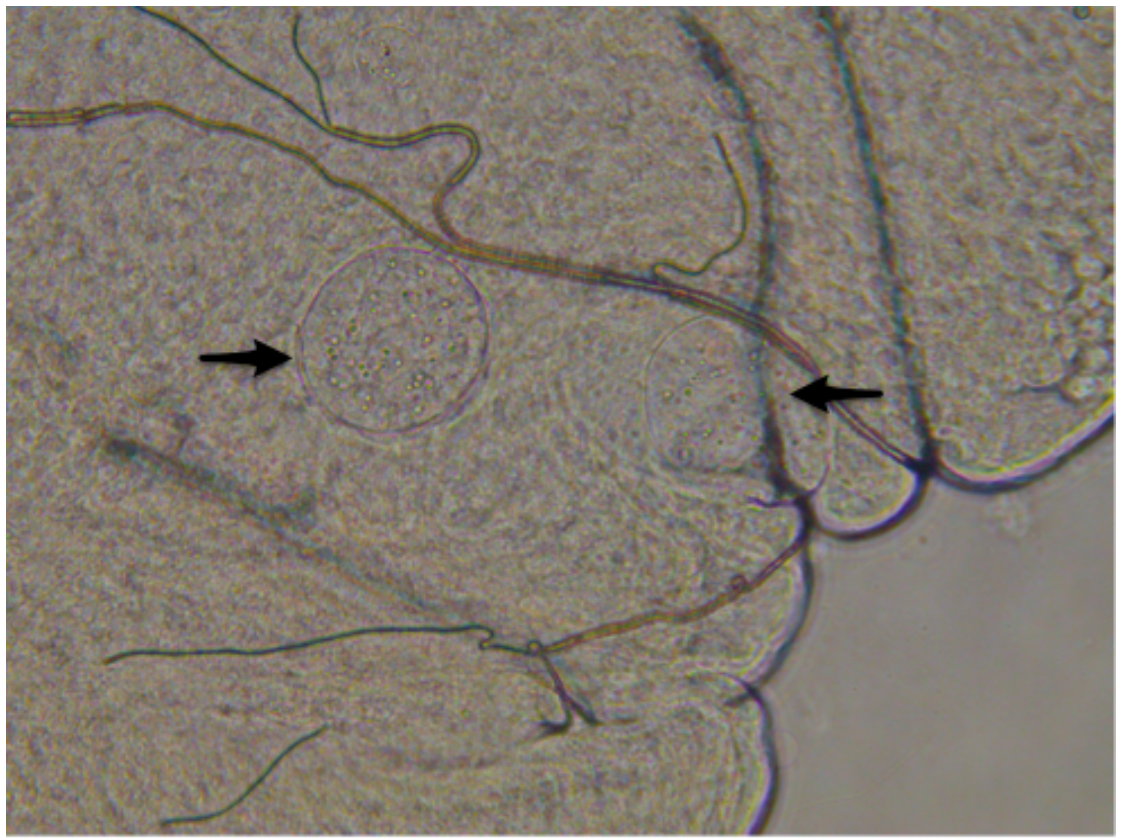

Figura 11 - Presença de oocistos no epitélio do intestino médio de fêmeas adultas do mosquito Ae. aegypti. Visualização realizada em microscópio óptico por contraste de fase, com aumento de 400 vezes.

3.8.1 Análises de expressão de lipase na infecção por $P$. gallinaceum

A verificação da expressão de lipase foi realizada em dois momentos do processo infeccioso: primeiro ciclo gonotrófico (alimentação com sangue infectado) e no segundo ciclo gonotrófico (mosquito infectado) (Figura 12). A expressão relativa do gene L-Aa7055 foi determinada no intestino médio de fêmeas adultas e comparada com o grupo controle de animais não infectados. O gene constitutivo PRS7 foi utilizado como gene de referencia interno.

No primeiro ciclo gonotrófico, os mosquitos foram alimentados em pintainhos infectados, a dissecção para obtenção do intestino médio foi realizada 12, 15 e 18 horas após a alimentação em pintainhos infectados (Figura 12A). Esse momento do ciclo de vida do parasita no mosquito é caracterizado pela presença das formas imaturas de $P$. gallinaceum (gametócitos, zigoto e oocineto) no intestino médio do mosquito. O mosquito só é considerado infectado 24 horas após a alimentação na invasão do epitélio pelo oocineto móvel. A confirmação da infecção nesse caso foi realizada em mosquitos sobressalentes mantidos por sete dias para esse objetivo (Figura 12C). As parasitemias determinadas nos pintainhos utilizados para a infecção dos 3 lotes de mosquitos foram respectivamente: 2\%, 3,7\% e 5\%. 
No segundo ciclo gonotrófico, a medida da expressão foi realizada em mosquitos infectados. A primeira alimentação desses mosquitos foi realizada em pintainhos infectados conforme descrito para o primeiro ciclo gonotrófico. As parasitemias determinadas nos pintainhos utilizados para a infecção dos 3 lotes de mosquitos foram respectivamente: $6 \%, 4 \%$ e $7 \%$. Sete dias após a primeira alimentação, cinco fêmeas foram dissecadas para confirmação da infeç̧ão pela observação dos oocistos no intestino (Figura 12C). Quinze dias após a primeira alimentação os animais foram submetidos a uma segunda alimentação em camundongos não infectados e dissecados 12, 15 e 18 horas após a alimentação (Figura 12D).

O material obtido foi armazenado em freezer $-80^{\circ} \mathrm{C}$ até o procedimento de extração de RNA, síntese de cDNA e qPCR, descritos respectivamente nos itens: 3.3; 3.5 e 3.8 . 
A)
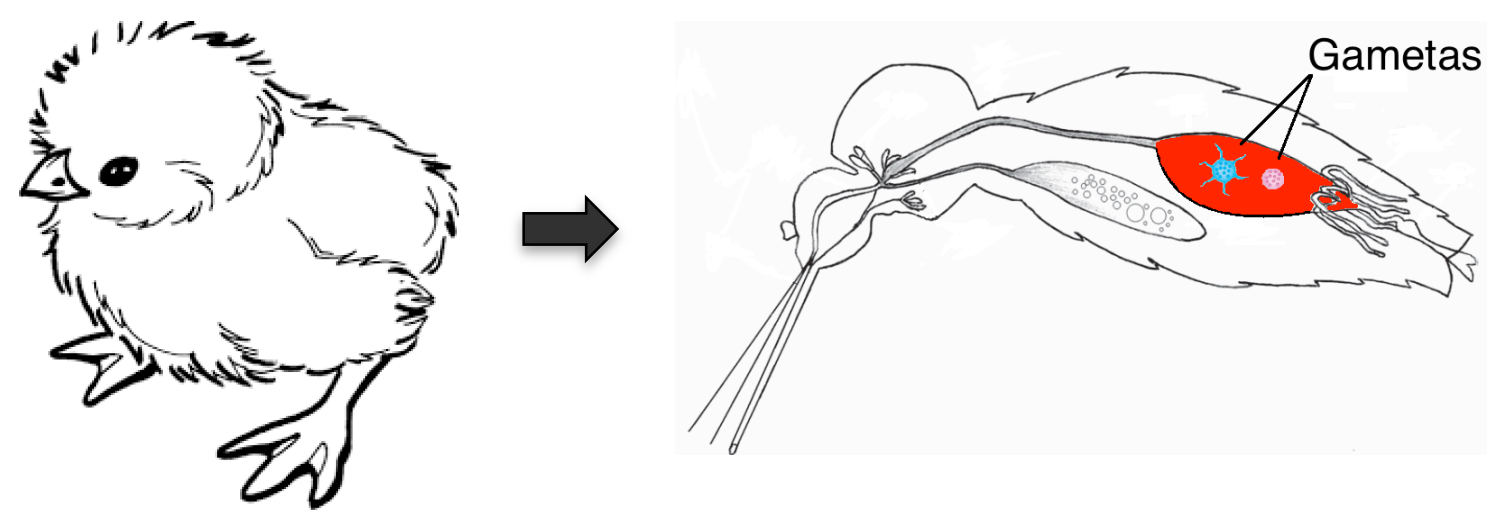

B)

C)

$3^{\circ}$ dia

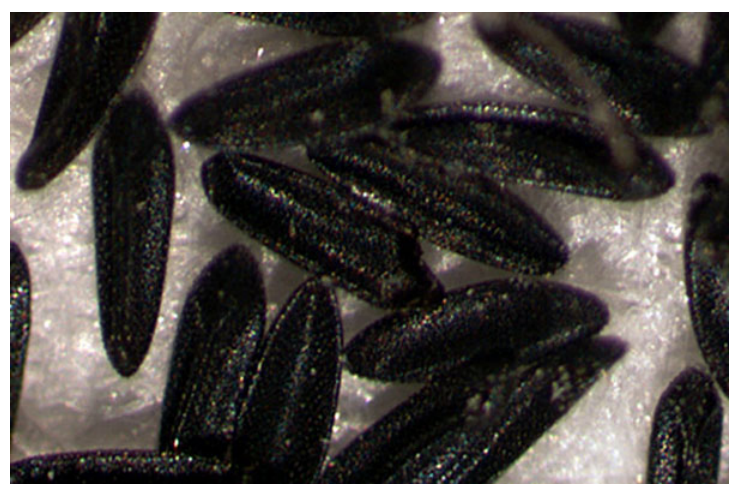

D)

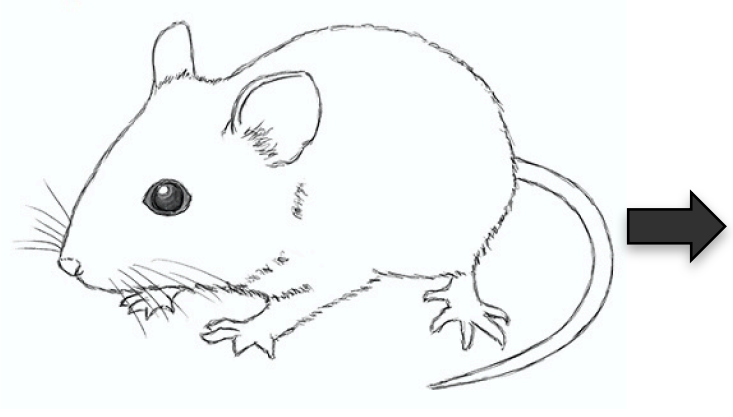

$7^{\circ}$ dia
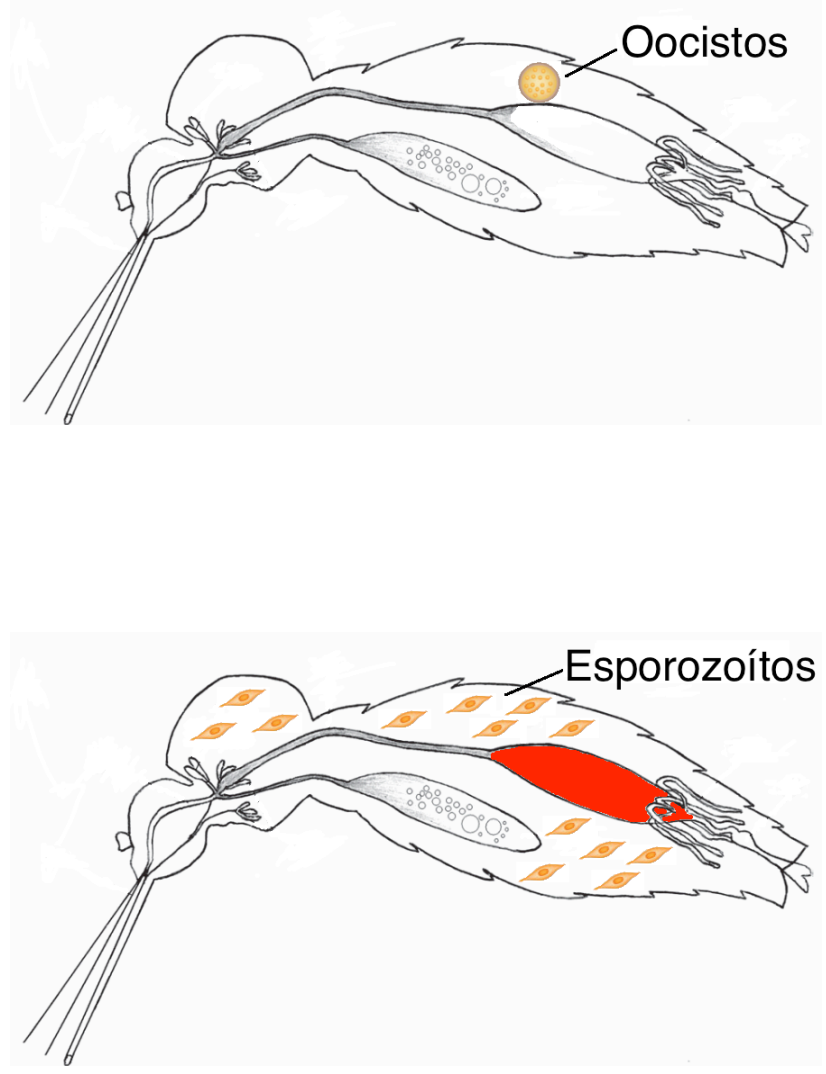

Figura 12 - Identificação dos momentos da infecção utilizados para análise por qPCR (A e D). A) Primeiro ciclo gonotrófico, alimentação em pintainhos infectados. B) Oviposição, a partir do $3^{\circ}$ dia após o primeiro repasto sanguíneo, fim do primeiro ciclo gonotrófico. C) Verificação da infecção, realizada no $7^{\circ}$ dia após o repasto, os animais infectados serão submetidos ao segundo repasto sanguíneo. D) Segundo ciclo gonotrófico, $15^{\circ}$ dia após o primeiro repasto, animais infectados alimentados em camundongos.Fonte: Gusmão (2007); Instituto Oswaldo Cruz (2016) 


\subsection{Infecção dos mosquitos Ae. aegypti por DENV2 e análise da expressão da lipase L-Aa7055}

Assim como na infecção com $P$. gallinaceum a manipulação e experimentos foram realizados no local sob autorização da Dra. Margareth de Lara CapurroGuimarães.

A infecção dos mosquitos é realizada através de alimentação artificial com auxilio de um instrumento chamado Glytube, que consiste em um método baseado em tubo cônico, parafilme e glicerina (Figura 13A) (COSTA-DA-SILVA et al., 2013). Eritrócitos humanos concentrados foram misturados com um sobrenadante de DENV2 e soro humano inativado em uma proporção de 10:10:1 respectivamente. A titulação final de DENV2 nessa mistura foi de $2,2 \times 10^{6} \mathrm{pfu} / \mathrm{mL}$. O período de alimentação foi de 45 minutos. As fêmeas não ingurgitadas foram retiradas, enquanto as engurgitadas foram mantidas em copos plásticos na presença de sacarose $10 \%$ ad libitum. Para facilitar a oviposição um tubo com algodão umedecido é colocado no fundo do copo de plástico.

A verificação da expressão da lipase L-Aa7055 foi realizada apenas no animal infectado por DENV2. Portanto, os pontos experimentais foram obtidos apenas no segundo ciclo gonotrófico. Quinze dias após a primeira alimentação os animais foram submetidos a uma segunda alimentação em camundongos não infectados e dissecados nos seguintes pontos experimentais: 12, 15 e 18 horas após a alimentação (Figura 13C).

Esse experimento foi realizado em duplicata biológica, sendo analisados 2 lotes de mosquitos. Os lotes de intestino, infectado e controle, foram obtidos nos pontos experimentais descritos, compostos por 15 animais. Todas as carcaças dos mosquitos infectados foram armazenadas individualmente para cada ponto experimental analisado. $\mathrm{O}$ material obtido foi armazenado em freezer $-80^{\circ} \mathrm{C}$ até o procedimento de extração de RNA, síntese de cDNA e qPCR, descritos respectivamente nos itens: 3.3 ; 3.5 e 3.8 .

A verificação da infecção foi realizada individualmente em 5 carcaças de cada ponto experimental para cada um dos lotes obtidos, ao todo foram processadas 30 carcaças. 
A)
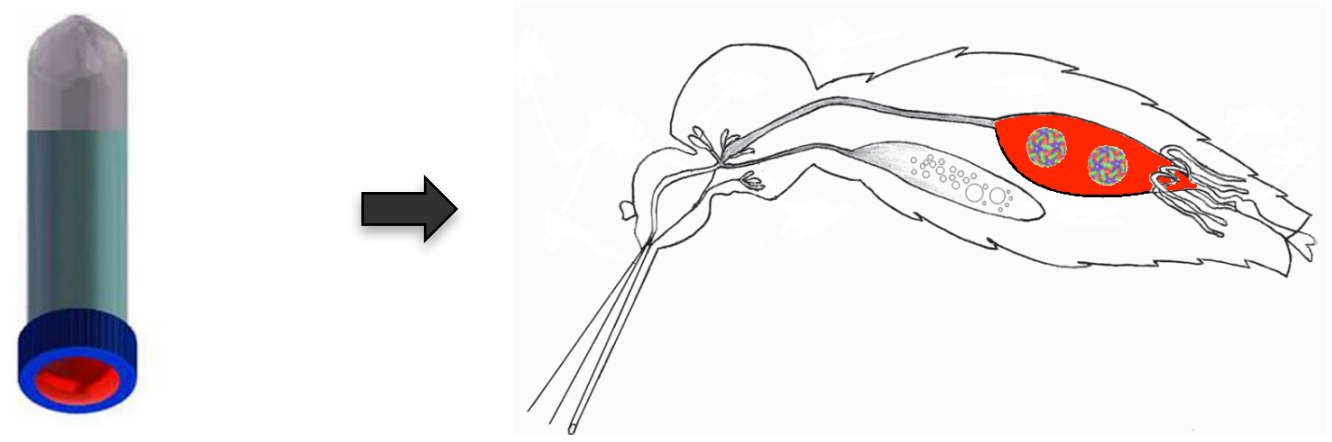

B)
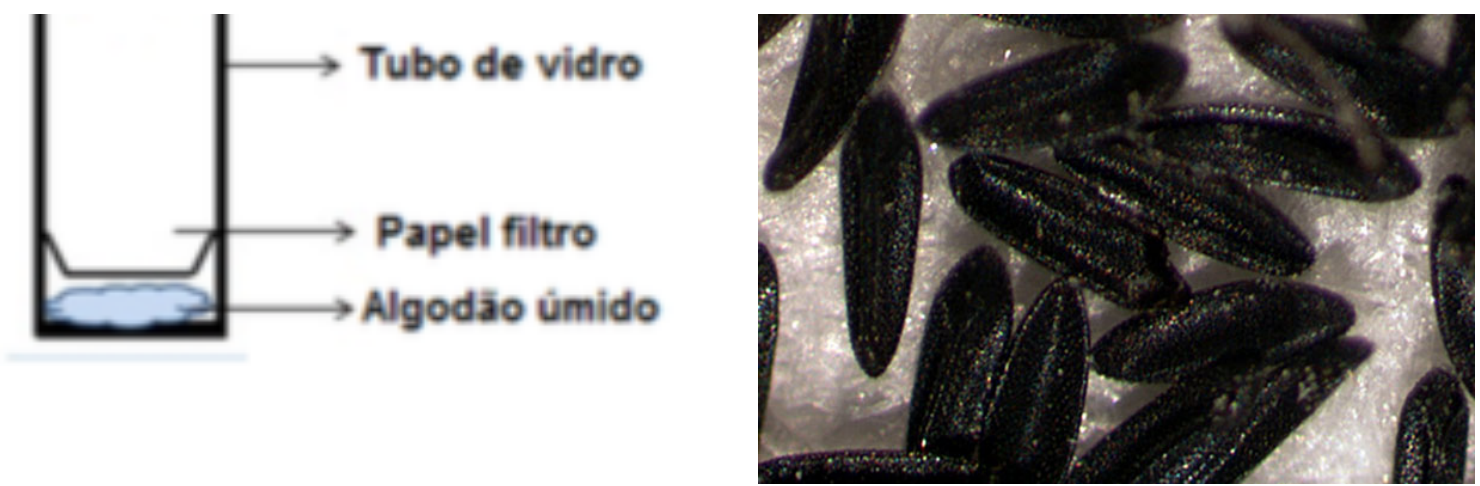

C)
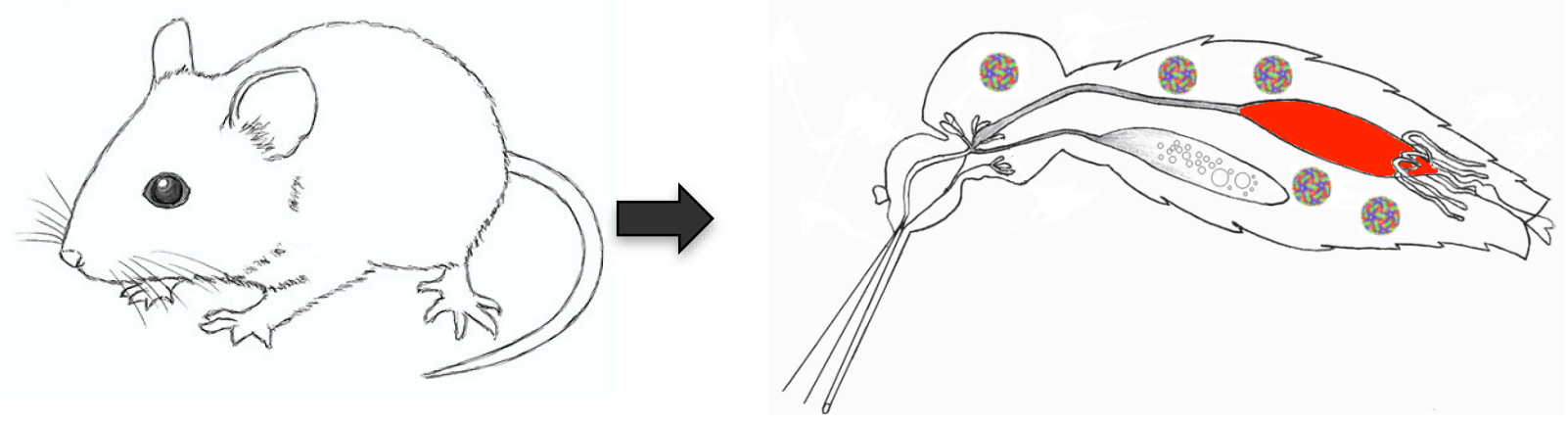

Figura 13 - Infecção do mosquito Ae. aegypti com DENV2. A) Alimentação em Glytube, presença da partícula viral no intestino. B) Recipiente para oviposição, $3^{\circ}$ dia após o primeiro repasto sanguíneo, fim do primeiro ciclo gonotrófico. C) Segundo ciclo gonotrófico, $15^{\circ}$ dia após o primeiro repasto, animais infectados alimentados em camundongos. Fonte: Gusmão (2007); IOC (2016); Ioshino (2013). 


\subsection{Clonagem e expressão das lipases provenientes das diferentes fases de desenvolvimento do mosquito Ae. aegypti (larva e adulto)}

Os procedimentos descritos nos itens 3.3 Extração de RNA total de intestino médio e resto do corpo (carcaça); 3.4 Tratamento com DNase; 3.5 Síntese da fita de cDNA e 3.6 Reação em cadeia com DNA polimerase em termociclador, foram utilizados previamente aos procedimentos e análises descritos subsequentemente para a clonagem e expressão das lipases.

3.10.1 PCR com iniciadores específicos para clonagem em pET-SUMO, pAE e pOP

A reações de PCR para amplificação da lipase AAEL705500 foi realizada no mesmo equipamento e programa descrito em 3.6, com exceção do número de ciclos utilizados. Os PCRs foram realizados no número máximo de ciclos indicado no manual da TAQ DNA polimerase, 40 ciclos.

Os iniciadores foram desenhados de forma a obter a sequência completa das lipase a ser clonada, o peptídeo sinal presente nas sequências de L-Aa7055 e LAa7051 foram identificados e removidos.

Para a clonagem e expressão da lipase de Ae. aegypti adulto em pET-SUMO foram utilizados os iniciadores nomeados como L-SUM-Aa7055 (Senso e Antisenso).

Para a clonagem e expressão das lipases de Ae. aegypti em vetor pAE, fase adulta e larval, foram utilizados os iniciadores AeAdul7055pae (Senso e Anti-senso) e AeLar7051pae (Senso e Anti-senso), respetivamente.

\subsubsection{Eletroforese de DNA em gel de agarose}

Para analisar os fragmentos de DNA derivados da amplificação com PCR foram feitas eletroforeses em gel de agarose. Os géis foram preparados na concentração final de $1 \%(\mathrm{p} / \mathrm{v})$ de agarose em tampão TAE (Tris-Acetato $8 \mathrm{mM}$, EDTA 0,4 mM, pH 8,5) e as amostras de DNA eram resolvidas em uma diferença de potencial de $80 \mathrm{~V}$.

Ao material a ser separado por eletroforese foi adicionado um tampão de amostra $(0,1$ volumes da amostra) contendo azul de bromofenol. Este último era usado para monitorar a migração da amostra e determinar o encerramento da eletroforese. Após a eletroforese, o DNA era evidenciado utilizando-se brometo de etídio $(0,5 \mathrm{mg} / \mathrm{ml})$ e visualizado em transiluminador de luz UV (312 nm). Esse 
procedimento foi realizado para os dois sistemas de clonagem e expressão utilizados.

\subsubsection{Eluição de fragmentos de cDNA}

A purificação de fragmentos de DNA a partir do gel de agarose foi feita utilizando o kit "GeneJetTM Gel Extraction Kit" (Thermo Fisher Scientific) de acordo com o protocolo sugerido pelo fabricante. Uma alíquota da amostra de DNA obtida foi analisada por eletroforese em gel de agarose e a quantidade de DNA obtida foi estimada por comparação com fragmento de DNA de tamanho e quantidade conhecida. Esse procedimento foi realizado para os dois sistemas de clonagem e expressão utilizados.

\subsubsection{Ligação dos fragmentos de cDNA em plasmídeo vetor}

Para clonagem dos fragmentos de cDNA obtidos pela amplificação por PCR, foi utilizada a T4 DNA ligase (Thermo Fisher Scientific). Para inserir os fragmentos dos cDNAs no vetor pAE, o inserto e o vetor foram submetidos a digestão com as enzimas de restrição apropriadas, para Ae. aegypti fase adulta (Kpnl e HindlII) e para Ae. aegypti fase larval (EcoRI e HindlII). Os produtos da digestão foram submetidos a um gel de agarose, as bandas referentes ao produto digerido foram recortadas e o DNA foi purificado do gel.

A reação foi realizada com uma unidade de T4 DNA ligase, tampão da DNA ligase, plasmídeo (pAE) e o produto do amplificado por PCR (purificado do gel de agarose, descrito acima). As concentrações de plasmídeo e produto do PCR utilizados foram 1:1 e 1:3, onde foi variada a concentração do produto do PCR. Para o plasmídeo pAE a mistura foi incubada por 1 hora a $22^{\circ} \mathrm{C}$.

Para o sistema pOP foi realizada uma subclonagem em vetor pGEM-T (promega). Os fragmentos de cDNA obtidos pela amplificação por PCR bem como o vetor pGEM-T foram submetidos a digestão com enzimas de restrição BamHI e HindIII. Os produtos da digestão foram submetidos a um gel de agarose, as bandas referentes ao produto digerido foram recortadas e o DNA foi purificado do gel. A inserção do fragmento de cDNA digerido ao vetor (pGEM-T) foi realizada através da reação catalisada pela T4 DNA ligase. As concentrações do vetor e inserto utilizados foram 1:1 e 1:2, variando a concentração do inserto. A mistura foi incubada por 1 hora a $22^{\circ} \mathrm{C}$ e deixada a $4^{\circ} \mathrm{C}$ por toda noite. 
A ligação os vetor Champion pET-SUMO foi realizada com auxilio do kit Champion $^{\mathrm{TM}}$ PET SUMO Expression System (Invitrogen) de acordo com as instruções presentes no manual do fabricante. As concentrações de plasmídeo e produto de PCR foram as mesmas descritas anteriormente, sendo 1:1 e 1:3, a variação foi feita para o produto da reação de PCR. Para o plasmídeo Champion pET SUMO a mistura foi incubada por toda noite a $25^{\circ} \mathrm{C}$.

\subsubsection{Transformação de bactérias competentes}

Aliquotas de $1 \mu \mathrm{L}$ dos respectivos plasmídeos foram adicionados a $30 \mu \mathrm{L}$ de células competentes $E$. coli OneShot ${ }^{\circledR} \operatorname{Mach} 1^{\mathrm{TM}}-\mathrm{T} 1^{\mathrm{R}}$ (Thermo Fisher Scientific) e mantidas no gelo por 30 minutos. Em seguida as células foram submetidas a um choque térmico a $42^{\circ} \mathrm{C}$ por 30 segundos e novamente transferidas para o gelo por 2 minutos. Foram então adicionados $500 \mu \mathrm{L}$ de meio LB, essa solução foi incubada por 1 hora a $37^{\circ} \mathrm{C}$, para recuperação das bactérias e expressão das proteínas envolvidas na resistência ao antibiótico de seleção.

Em seguida, a mistura foi plaqueada em placa com meio LB mais o antibiótico de seleção e incubadas por toda a noite a $37^{\circ} \mathrm{C}$, obtendo-se dessa forma colônias isoladas. As colônias obtidas foram submetidas a PCR de colônia, as colônias que apresentaram o inserto foram crescidas por toda a noite em $3 \mathrm{~mL}$ meio LB líquido na presença do antibiótico de seleção.

Foram utilizadas células competentes distintas para cada sistema de expressão, as células utilizadas bem como variações do protocolo base aqui descrito podem ser observados nos itens: 3.10.8, 3.10.9 e 3.10.10.

\subsubsection{Purificação de plasmídeos a partir de cultura bacteriana}

Os plasmídeos foram purificados com auxílio do kit GeneJET Plasmid Miniprep Kit (Thermo Fisher Scientific) a partir de 1,5 mL de cultura bacteriana após crescimento por toda a noite a $37^{\circ} \mathrm{C}$. A quantificação do DNA foi realizada em Nanodrop, e a qualidade da amostra foi verificada. 


\subsubsection{Reação de sequenciamento de DNA}

O sequenciamento foi realizado no aparelho ABIPRISMTM 3100 Genetic Analyzer (Hitachi, Ltd., Tóquio, Honshu, Japão) conforme recomendações do fabricante. A reação de seqüenciamento foi realizada utilizando-se $2 \mu \mathrm{L}$ da mistura da reação "Big Dye Terminator Mix" (Applied Biosystems), 100-200 ng de DNA, 9,6 pmol de cada iniciador específico para a sequência do plasmídeo pGEM-T conforme descrito pelo fabricante, Tris- $\mathrm{HCl} 200 \mathrm{mM} \mathrm{pH} \mathrm{9,0} \mathrm{e} \mathrm{MgCl}_{2} 5 \mathrm{mM}$ em um volume final de $15 \mu \mathrm{L}$. A reação foi incubada por 2 minutos a $95^{\circ} \mathrm{C}$, seguida de 35 ciclos de 45 segundos a $96{ }^{\circ} \mathrm{C}, 30$ segundos a $50{ }^{\circ} \mathrm{C}$ e 4 minutos a $60{ }^{\circ} \mathrm{C}$. Terminada a reação, as amostras foram precipitadas com etanol $100 \%$ e glicogênio $1 \mathrm{mg} / \mathrm{mL}$, lavadas com etanol $70 \%$, desnaturadas a $94{ }^{\circ} \mathrm{C}$ por 5 minutos e aplicadas no seqüenciador automatizado.

A qualidade das sequências geradas foi analisada no programa BioEdit versão 7.0.5.3. A análise de similaridade foi feita no programa BLAST disponível no banco de dados públicos NCBI (NCBI, 2016b).

\subsubsection{Clonagem e expressão em pET-SUMO}

A construção do vetor de clonagem e de expressão e a expressão da lipase presente na forma adulta do mosquito Ae. aegypti em sistema bacteriano foi realizada utlizando o Kit Champion ${ }^{\mathrm{TM}}$ pET SUMO Expression System (Invitrogen) de acordo com o manual do fabricante. O vetor utilizado foi o Champion pET SUMO e a expressão foi realizada em linhagem de E. coli BL21(DE3) utilizando IPTG como agente indutor. A indução foi realizada por aproximadamente 20 horas a $20{ }^{\circ} \mathrm{C}$. Esta estratégia foi bem sucedida para a clonagem da enzima de Ae. aegypti em sua fase adulta.

\subsubsection{Clonagem e expressão em pAE}

Após a digestão do vetor e inserto, a reação de ligação dos mesmos foi descrito na seção 3.10.4., o plasmídeos purificados desse passo foram utilizados para transformar células competentes de expressão ( $E$. coli) como foi descrito na seção 3.10.5. e dessa forma gerar a linhagem utilizada na expressão das lipases recombinantes. 
O sistema permite a transformação de diversas linhagens de $E$. coli, com objetivo de aumentar a quantidade de enzima expressa na porção solúvel. Bactérias BL21(DE3), Origami(DE3) e BL21 Star (DE3)pLysS foram transformadas separadamente com os plasmídeos pAE contendo a sequência codificante para as proteínas L-Aa7055 e L-Aa7051. As colônias bacterianas foram crescidas em meio LB líquido na presença de ampicilina $(50 \mu \mathrm{g} / \mathrm{mL})$, cultivadas a $37^{\circ} \mathrm{C}$ até atingirem uma $\mathrm{DO}_{600}:$ 0,4 - 0,7 e induzidas com IPTG (1 mM) sob agitação de $200 \mathrm{rpm}$ a $20^{\circ} \mathrm{C}$ durante toda a noite.

As células de culturas induzidas e não induzidas foram coletadas em diversos intervalos de tempo (indo de tempo 0 a 4 horas), cada alíquota coletada era submetida a centrifugação 13,2 rpm por 60 segundos onde o sedimento celular foi coletado e armazenado a $-20^{\circ} \mathrm{C}$, foram coletadas duas alíquotas no tempo final (10 a 15 horas) ambas foram centrifugadas uma foi utilizada para lise e purificação e a segunda para verificar a indução. As alíquotas, induzidas e não induzidas, foram ressuspendidas e a produção da enzima recombinante foi verificada por SDS-PAGE.

\subsubsection{Clonagem e expressão em pOP}

O plasmídeo pGEM-T/Lip e o vetor pOP5MP (plasmids for Overproduction of Proteins; $M=$ MPB fusion; $P=$ PreScission site ) foram submetidos a digestão com enzimas de restrição BamHI e HindlII. O sistema possui a característica de produzir proteínas recombinantes em abundância e apresenta uma proteína ligadora de maltose (MBP), que auxilia na solubilidade e pode ser usada como alternativa a purificação por níquel. Os produtos da digestão foram submetidos a um gel de agarose, as bandas referentes ao produto digerido foram recortadas e o DNA foi purificado do gel. A inserção do fragmento de cDNA digerido ao vetor (pGEM-T) foi realizada através da reação catalisada por T4 DNA ligase (Fermentas, Life Sciences).

O produto das ligações, plasmídeo pOP5MP/AaLip foi utilizado para transformar bactérias competentes XL10 Gold por choque térmico o que foi seguido da etapa de crescimento. Após o período de crescimento todo o material foi plaqueado e incubado por toda noite a $37{ }^{\circ} \mathrm{C}$ em placas com LB Agar contendo ampicilina $(50 \mu \mathrm{g} / \mathrm{mL})$, Xgal $(80 \mu \mathrm{g} / \mathrm{mL})$ e IPTG $0,5 \mu \mathrm{M}$, para crescimento e seleção de colônias com inserto, descrição completa na seção 3.10.5. A purificação por miniprep para obtenção do plasmídeo pOP5MP/AaLip foram realizados conforme 
descrito na seção 3.10.6.

Bactérias BL21(DE3) foram transformadas com os plasmídeos pOP5MP/AaLip contendo a sequência codificante para a proteína L-Aa7055. As colônia bacteriana foi crescidas em meio LB líquido na presença de ampicilina (50 $\mu \mathrm{g} / \mathrm{mL}$ ), cultivadas a $37^{\circ} \mathrm{C}$ até atingirem uma $\mathrm{DO}_{600}: 0,4-0,7$ e induzidas com IPTG (1 mM) A indução foi realizada por 24 horas a $37^{\circ} \mathrm{C}$. A verificação da indução foi feita por gel de SDS-PAGE.

\subsubsection{Procedimento para lise das células bacterianas}

O material proveniente da indução com IPTG foi centrifugado, 8000 RPM por 4 minutos, a porção solúvel foi descartada e a porção celular (precipitado) foi ressuspendida em tampão de lise e submetida a lise. O tampão de lise é composto por: $0,3 \mathrm{~mL}$ de fosfato de potássio $\left(\mathrm{KH}_{2} \mathrm{PO}_{4} 1 \mathrm{M}\right) ; 4,7 \mathrm{~mL}$ de fosfato de potássio dibásico $\left(\mathrm{K}_{2} \mathrm{HPO}_{4} 1 \mathrm{M}\right) ; 2,3 \mathrm{~g}$ de $\mathrm{NaCl}$; 0,75 g KCl; glicerol $10 \mathrm{~mL}$; triton $\mathrm{X}-100$ 0,5 mL e imidazol $68 \mathrm{mg}$, o pH é corrigido para 7,8 e volume final acertado para $100 \mathrm{~mL}$.

Após a ressuspensão, o material foi submetido a 3 ciclos de congelamento seguido de descongelamento em um banho a $42{ }^{\circ} \mathrm{C}$. A lise foi realizada em um sonicador de ponteita (Unique, Indaiatuba, SP, Brasil), sob uma potência de $20 \%$, o material foi sonicado 6 vezes por 10 segundos sendo esse ciclo repetido 4 vezes.

Após a lise o material foi centrifugado, 8000 RPM por 4 minutos, a porção insolúvel foi ressuspendida em água Milli Q. O material obtido foi submetido a eletroforese para verificação do perfil proteíco e utilizado para verificação da atividade de lipase.

\subsection{Processo de renaturação da lipase recombinante obtida em sistema de expressão pET-SUMO (L-Aa7055/Sum)}

A lipase recombinante L-Aa7055/Sum obtida majoritariamente na porção insolúvel (Figura 31, raia 5), foi desnaturada na presença de tampão fosfato $50 \mathrm{mM}$ $\mathrm{pH} 7,8$ na presença de $1 \mathrm{M}$ de ureia. Foram utilizados $3 \mathrm{~mL}$ do material lisado presente na porção insolúvel, onde foram adicionados $1 \mathrm{~mL}$ do tampão com ureia. Esse material foi incubado por 30 minutos em banho de gelo, sendo invertidos manualmente de 10 em 10 minutos.

O processo de renaturação foi realizado através de diversas diálises, que foram realizadas em tampão fosfato $50 \mathrm{mM} \mathrm{pH} \mathrm{7,8} \mathrm{em} \mathrm{concentrações} \mathrm{decrescentes}$ 
de ureia, as diálises foram realizadas em períodos de 3 horas em cada concentração de ureia. As concentrações de ureia utilizadas foram: $4 \mathrm{M}, 2 \mathrm{M}, 1 \mathrm{M}, 0,5 \mathrm{M}$ e o tampão final na qual a enzima recombinante foi mantida não continha ureia.

\subsection{Verificação da lipase recombinante L-Aa7055/Sum por sequenciamento em LC-MS e da lipase proveniente de homogeneizado bruto em orbitrap}

As análises para a identificação proteômica foram realizadas no Laboratório de Espectrometria de Massas do Instituto Butantan. A banda correspondente a LAa7055/Sum (50 Kda) foi recortada do gel de SDS-PAGE, tratada e submetida a digestão com $40 \mathrm{ng} / \mu \mathrm{L}$ de quimotripsina. Os materiais oriundos da digestão por tripsina foram analisados através da cromatografia líquida acoplada a espectrometria de massas (LC-MS), utilizando um sistema UFLC binário (20A Prominence, Shimadzu Co., Japan) acoplado ao espectrômetro de massas do tipo Electrospray Ion Trap - Time of Flight (ESI-IT-TOF) (Shimadzu Co., Japão), sob a supervisão do Dr. Daniel Carvalho Pimenta.

Para as análises por LC-MS, as amostras foram ressuspendidas em água / 0,1\% Ácido Acético e analisadas em uma coluna C18 (Discovery C18, $5 \mu \mathrm{m}, 50 \mathrm{~mm}$ x $2.1 \mathrm{~mm}$ ), tendo como solventes (A) Ácido Acético / água (1:999) e (B) Ácido Acético / ACN / água (1:900:99). Por meio de um fluxo constante de 0,2 mL/min, o gradiente variou de 5 a $40 \%$ de solvente $\mathrm{B}$, durante 35 minutos, a $37{ }^{\circ} \mathrm{C}$, e monitorado a $214 \mathrm{~nm}$ por um detector Shimadzu SPD-M20A PDA. Seguida a etapa cromatográfica, foram realizadas as análises por espectrometria de massas, de acordo com os seguintes parâmetros: a voltagem utilizada da interface foi de 4,5 KV e a voltagem do detector, $1,76 \mathrm{KV}$, com temperatura de $200{ }^{\circ} \mathrm{C}$; a fragmentação foi causada por gás de colisão argônio, com 50\% de energia; e os espectros foram obtidos na faixa de 50 a 2000 m/z. O padrão de fragmentação para cada amostra foi processado pelo programa MASCOT (Ion Search) versão in house (versão 2.4.0) ( PERKINS et al., 1999) para análises proteômicas e/ou pelo Peaks Studio V7 (MA et al., 2003) para sequenciamento 'de novo' e análises proteômicas e de comparação de sequências, realizando as buscas contra o banco de dados do Uniprot (NCBI) e de transcritos obtidos para Ae. aegypti depositados no banco de dados VectorBase (NIAID, 2016) 
Como tentativa de identificação da lipase digestiva de fêmeas adultas do mosquito $A$ e. aegypti, utilizamos o material proveniente de uma cromatografia de troca iônica (aniônica), a partir do homogeneizado do intestino médio. Essa cromatografia faz parte do primeiro passo de purificação descrito no mestrato (FILIETAZ, 2011).

A fração que correspondente ao pico de atividade de lipase, utilizando butirato como substrato, foi desalinizada contra tampão bicarbonato de amônio 200 mM, aquecida a $60^{\circ} \mathrm{C}$ por 15 minutos para denaturação, liofilizada, ressuspendida em tampão de corrida e aplicada a um gel de SDS-PAGE. As duas bandas mais fortes com massa aproximada a da lipase foram recortadas e digeridas, todas as outras bandas presentes no gel foram recortadas e digeridas separadamente e o produto da digestão foi reunido no mateial final. A digestão foi realizado conforme descrito acima. O material obtido na digestão foi analisado em um sistema nanoLC EasyLTQ Orbitrap Velos-ETD localizado no CEFAP USP (Centro de Facilidades e Apoio a Pesquisa), sendo o material das bandas mais fortes analisado separadamente do resto do gel.

\subsection{Seleção de sequências, alinhamento e árvore filogenética}

A sequência das lipases pancreática e gástrica humana foram obtidas através de uma busca nominal no banco de dados do Uniprot (UNIPROT, 2016), sendo selecionadas as lipases melhor caracterizadas no ser humano (Figura 14).

As lipases pancreática e gástrica humana foram utilizadas para a realização de um BLASTp contra o banco de dados de proteínas do VectorBase (NIAID, 2016) no dia 27/01/2015. Foram selecionados os seguintes organismos: Ae. aegypti (AAEL), Anopheles darlingi (ADAC), Anopheles gambiae (AGAP), Biomphalaria glabrata (BGLB), Culex quinquefasciatus (CQU), Culex pipiens (CPIJ), Ixodes scapularis (ISCW), Lutzomyia longipalpis (LLO), Musca domestica (MDOA), Pediculus humanus (PHUM), Phlebotomus papatasi (PPA) e Rhodnius prolixus (RPR), sendo obtidas as 10 primeiras sequências anotadas como lipase, alguns organismos não tiveram as suas sequências anotadas portanto as sequências que retornaram para o blast nesses organismos não foram utilizadas.

As lipases pancreática e gástrica humana ainda foram utilizadas para a realização de BLAST (NCBI, 2016b), contra o banco de dados do Uniprot, essa busca foi realizada no dia 06/02/2015. O primeiro BLAST foi realizado contra um 
banco de insetos (taxid: 6960) e o segundo contra um banco de crustáceos (taxid: 6657). O BLAST com a lipase pancreática humana nos permitiu selecionar 10 sequências em insetos, sendo o E-value mínimo de 6e-96 (Cerapachys biroi) em crustáceos foram obtidas 3 sequências sendo o E-value mínimo de 1e-63. 0 BLAST com a lipase gástrica humana permitiu a seleção de 10 sequências em insetos, sendo o E-value mínimo de 2e-89 (Diaphorina citri) em crustáceos foram obtidas 3 sequências sendo o E-value mínimo de 1e-59 (Litopenaeus vannamei).

As sequências de proteínas bem caracterizadas na literatura foram obtidas no banco de dados do Uniprot, a maior parte dessas sequências corresponde a lipases digestivas e uma fosfolipase $\mathrm{A} 1$ de insetos. As sequências selecionadas estão descritas a seguir, foram selecionadas 2 lipases de Drosophila melanogaster lip1 (DROME-LIP1) e lip3 (DROME-LIP3) (PISTILO et al., 1998), fosfolipase A1 de Dolichovespula maculata (DOLMA-PHOSPA1) (SOLDATOVA; KOCHOUMIAN; KING, 1993), lipases digestivas de Helicoverpa armigera (HELAR-LIP) (CAMPBELL et al., 2008) e Mamestra configurata (MAMCO-LP2) (TOPRAK., 2008) que são similares a lipase de Lymantria dispar (SPARKS et al., 2013), a lipase digestiva e anti-viral de Bombyx mori (BOMMO-LIP) (PONNUVEL et al., 2003) e algumas lipases de Epiphyas postvittana (EPIPO-LIPn3, EPIPO-LIPn7 e EPIPO-LIPn9) (CHRISTELLER et al., 2010).

O último passo da busca de sequências foi realizado através de busca nominal por lipase pancreática e gástrica no banco de dados do UniProt, tendo como objetivo a obtenção de lipases encontradas em vertebrados, essas buscas foram realizadas dia 09/02/2015 para as lipases pancreáticas e dia 12/02/2015 para as gástricas. As sequências de vertebrados para lipase pancreática obtidas para mamíferos foram Rattus norvegicus (RATNO-LP), Mus musculus (MUSMU-LP) e Bos taurus (BOSTAU-LP), para aves Gallus gallus (GALGA-LP) e Meleagris gallopavo (MELGA-LP), para peixes Thunnus orientalis (THUOR-LP) e Ictalurus punctatus (ICTPU-LP), para anfíbios Xenopus tropicalis (XENTR-PLRP2) e para répteis Chelonia mydas (CHEMY-PLRP1). Foram encontradas apenas sequências de mamíferos para lipases gástricas de vertebrados, Rattus norvegicus (RATNOLG), Canis familiaris (CANFA-LG) e Bos taurus (BOSTAU-LG).

As sequências obtidas foram analisadas no "software" MEGA6 e o alinhamento foi realizado com a utilização da ferramenta ClustalW, presente no MEGA. O resultado do alinhamento foi utilizado para o cálculo de uma 
árvore filogenética usando máxima verossimilhança, foram utilizados 1000 ciclos de bootstrap.

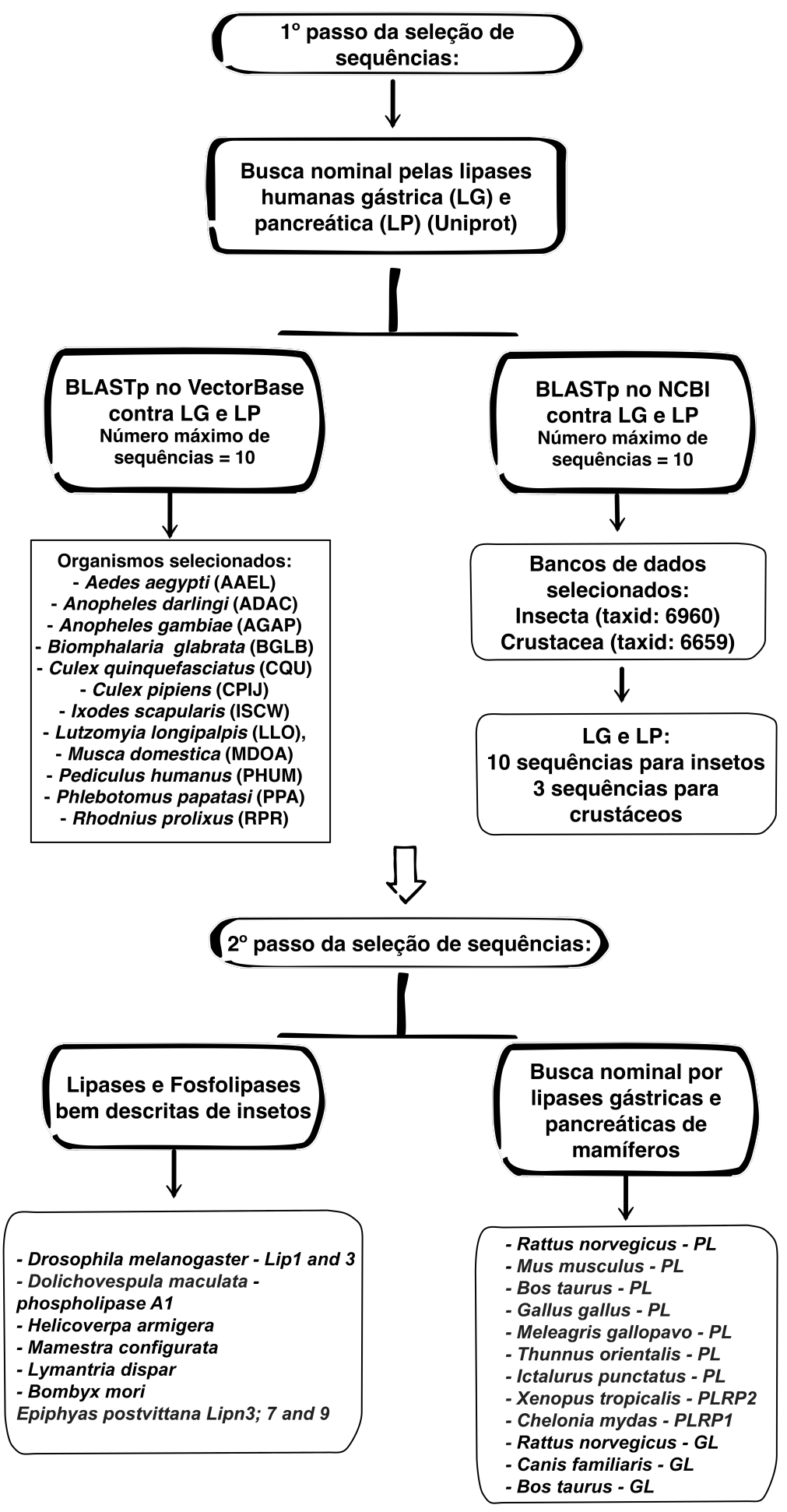

Figura 14 - Esquema da seleção das sequências de lipase usadas para alinhamento e construção da árvore filogenética. 


\section{RESULTADOS}

Os resultados obtidos, bem como os gráficos e imagens relacionadas aos experimentos realizados estão descritos a seguir.

\subsection{Alinhamento das lipases digestivas de Ae. aegypti com as lipases digestivas descritas}

A partir dos bancos de dados VectorBase e Uniprot (NCBI) selecionamos 139 sequências de diversas ordens de insetos, crustáceos, aracnídeos e vertebrados. As lipases L-Aa7055 e L-Aa7051 que foram preditas como digestivas em Ae. aegypti (FILIETAZ, 2011), foram analisadas por alinhamento, o que permitiu a sua comparação estrutural com as lipases de diversas espécies de animais. Na figura 15 escolhemos algumas sequencias para um alinhamento parcial representativo, demonstrando a identificação dos domínios e resíduos utilizados na análise das sequências. 
HOMSA-LP
NECRU-LN
TYTSE-LN
DAPPU-LN
DOLMA-PL
CAVPO-PR
LAa7055
LAa7051
BOMMO-LN

HOMSA-LP
NECRU-LN
TYTSE-LN
DAPPU-LN
DOLMA-PL
CAVPO-PR
LAa7055
LAA7051
BOMMO-LN

HOMSA-LP NECRU-LN TYTSE-LN DAPPU-LN DOLMA-PL CAVPO-PR LAa 7055 LAa7051 BOMMO-LN

HOMSA-LP NECRU-LN TYTSE-LN DAPPU-LN DOLMA-PL CAVPO-PR LAa7055

LAa7051 BOMMO-LN

HOMSA-LP NECRU-LN TYTSE-LN DAPPU-LN DOLMA-PI CAVPO-PR LAa7055 LAa7 051 BOMMO-LN

HOMSA-LP NECRU-LN TYTSE-LN DAPPU-LN DOLMA-PL CAVPO-PR LAa7055

LAa 7051 BOMMO-LN

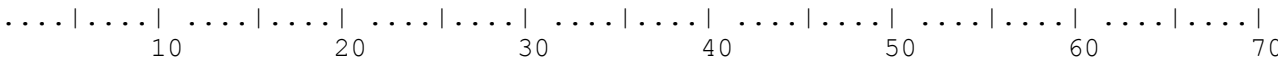

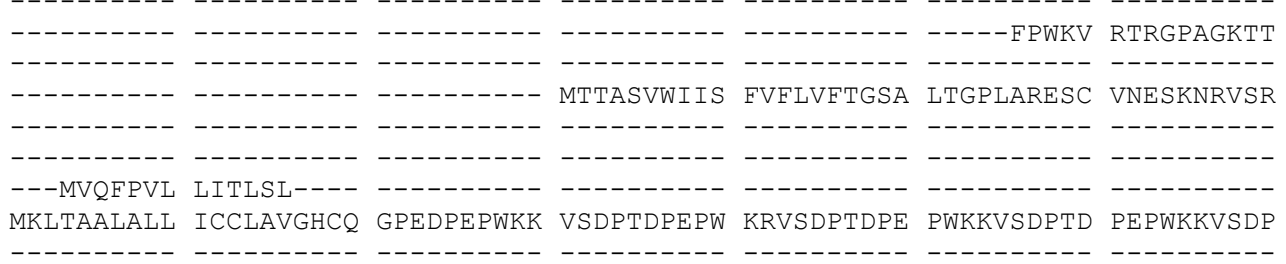

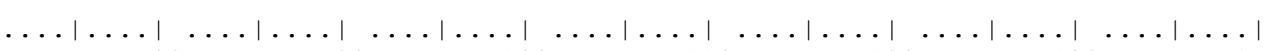
80 90 100 110 120

130 VAWSWLCLS VTYGGVIPQN DSLQHGLIGG DKEVCMKELG CFKITDDFKH LIHR-PINVL ---MKCCWII LIYIPLLGFE ELY-AFKLKN THYTLFARNA KKQICMRDLG CFEITSDFIN DKKR-PFNVL DFRALIKHGR DYHKDLVQKQ EPSTAVLQTA DVQQLDSKME PITYCYGEIG CIVIDDSWYD PVHR-PINQE

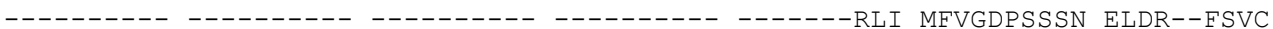
---------------------------------- AEVCYSHLG CFSDEKPWAG TSQR-PIKSL $----------------------A$ AF EVHSSYAENR RLQLVRDIDG TQQLVNPNPY RVLN--AHLE TDPEPWKRAS DPTDPEPWQE VTDPTDPEPW KKVSDPIEPE PWALIPDGAG HLHIVNINPV NIPEGEDEIE ----------------------------------- MPDGEG VPHLVDLEEP -----AEEDI

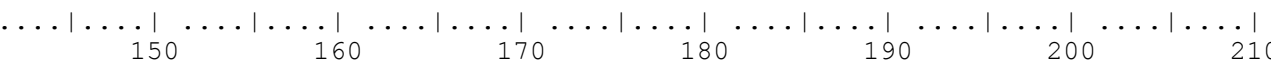
PWSPKDVNTR FLLYTNENPN NFQEVAA-DS SSISGSNFKT NRKTRFIIHG FIDKGEEN-W LANVCKNLFK PHDRATINTK CLLYTRKNAK ESQQLIARDK STFEESNFNP ANPTKFIVHG FMDSELYGPW MLDMKDEFLM PKHKHLINTQ FLLFTKDNLN KSYALIGDIE KNLKNSPLDT SLTTIFIVHG FLDMQYFVTW MDNLKDEILK PLPREKINTR FILHTRQRPT QDTMLYANDL DSIRYSTFDP SKPTQFLVHG FIDDGTVR-W MKRLTENLLA PFSNDTVKMI FLTRENRKHD FYTLDTMNRH NEFKKSIIKR --PVVFITHG FTSSATEK-N FVAMSEALMH PSDPKKINTR FLLYTNENQN SYQLITATDI ATIKASNFNL NRKTRFIIHG FTDSGENS-W LSDMCKNMFQ RSFNAQSDII FRLYTRKNPE KHQILKPNDT SSILNSNFNA DLPTRFLIHG WNQNGESD-I LIELRRSYLS PLENPETDVV FRMYTRRNPL HEQLIRWDDP SSISNSNFNP ANPTRFLIHG WVEGEDAT-L HWVIKDHYMR LMSRNGANNQ YWLFTRRNQN NHQVITNGNV NSIRNSNYNG NLPLFVIVHG WNSNGNSA-V NTMIRPALLA Alça $\beta 5$ -

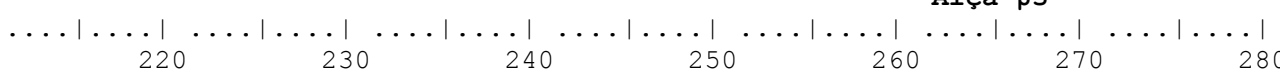
$220 \quad 230 \quad 240 \quad 250 \quad 260$ VESVNCICVD WKGGSRTG-- ------YTQ ASQNIRIVGA EVAYFVEFLQ SAFGYSPSNV HVIGHSLGAH HGDYNIIVVD WSGGNKPP-- ------YYQ ATSNTRVVAA EMALIVQALE KYFGAKREEF HIIGHSLGSH NDKYNVIIVD WSGGNQLP-- ------YTQ AVANTRVVGA EIAFLIGKME RILGLNPQSC HIIGHSLGAH HGDYNVIIVN WGGGSLPM-- ------YSQ ATANTRVVGL EIAYMVNTMI THFGVDPGMV HLLGHSLGAH TGDFLIIMVD WRMAACTDEY PGLKYMFYKA AVGNTRLVGN FIAMIAKKLV EQYKVPMTNI RLVGHSLGAH VEKVNCICVD WKGGSKAQ-- ------YSQ ASQNIRVVGA EVAYLVQVLS TSLNYAPENV HIIGHSLGAH VEDFNVIGVD WGEGALTIN- ------YVM ARKRVESVGL VTSQLIDTLV DASGVILDSI YVIGHSLGAH VGDFNVINVD WGAGAQTIN- ------YYA ARNRVGGVGM IVSRVIDTIR ATTGQSLDMI NVVGFSLGGH VSDCNVIVVD WRG-LANGL- ------YNT AVNGVPSVGQ FLGNFLVWLI NNGGGNWGRV HLIGFSLGAH

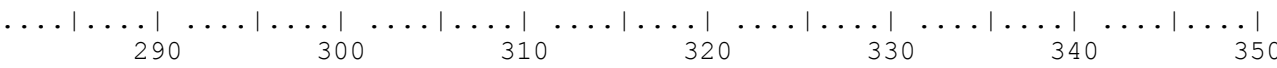
AAGEAGRRTN G----TIGRI TGLDPAEPCF QGTPELVRLD PSDAKFVDVI HTDGAPIVPN LGFGMSQVVG IAGYTGERLK -----TLGRI TGCDPAEPYF QNMPPSVRLD PTDADYVDVI HSDATDIMF- IGFGMSHPVG IAGYAGERLK ----HLGRI TALDPAGPYF EGMPSSVIID PTDADFVDAI HTDLNSFVV- TGLGIKDPVG TVSYAGERIE -----GLGRI TGLDPAEPYF AEMPSHVRLD PTDAKFVDAI HTDTRTILL- LGYGMLEPV ISGFAGKRVQ ELKLGKFSEI IGLDPAGPSF KKNDCSERIC ETDAHYVQIL HTSSN----- --LGTERTLG TAGEAGKRLN G----LVGRI TGLDPAEPYF QDTPEEVRLD PSDAKFVDVI HTDISPILPS LGFGMSQKVG VAGIVGKHQR G----QLNTI VGLDPAGPLF SLNSSDILN- QNHAQYVEMV STGAR----- -LLGTYEPL AAGNAGKGQN G----LLNSV IALDPAGPLF SQGQADILS- ASDAIYTEAI YTNAG----- -NLAFDAPLA VVGNAGROAG G----RPNRV TGLDPAGPRW G-GNNQALN- RNAGAYVEAI HTDGG----- -ILGIFDRT

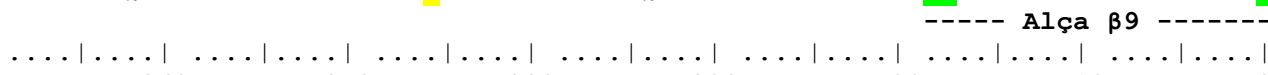
$\begin{array}{lllll}360 & 370 & 380 & 390 & 400\end{array}$ $\ldots 1 \ldots 1 \ldots 1$ HLDFFPNGGV E-MPGCKKNI LSQIVDIDGI WEGTRDFAAC NHLRSYKYYT DSIVNPDG-F AGFPCASYNV HVDFFPNNGR N-QPGCKS-A KFKSFITDGL NEGARRFASC NHQRSLDFMH HSINYRKVTP VGYECPNWQD HVDFYPNNGR D-QPGCKTHH RLISFITDGF IEGMRKAVSC SHQRAVDFFT TSINHHKCLF TAFPCSNWTD HLDFYPNGGR D-QPGCDPVD IALDAITEDM ITGGRELAAC NHLRCIEFFI DSLVPGNT-F VGYECPDNDA TVDFYINNGS N-QPGCRYII G------- ------ETC SHTRAVKYFT ECIRRECC-L IGVPQSKNPQ HMDFFPNGGK D-MPGCKTGI S------- -------C NHHRSIEYYH SSILNPEG-F LGYPCASYDE DANFYPNGGL E-QAGCGL-- -------- ---DLFGIC AHARSWIYFA ETVTNGKG-F RGIKCAMIED QANFYPNYGR S-QPGC---- -------- -----ITSIC AHNRVNELFA ESVSTANH-F IAMECADYNE HGDFYPNGGR NPQPGCR--- -------- -----VSTC SHSRAYELYA STVRHNR--F VGRLCNNLNQ 


\begin{tabular}{|c|}
\hline HOMSA-LP \\
\hline NECRU-LN \\
\hline TYTSE-LN \\
\hline DAPPU-LN \\
\hline DOLMA-PL \\
\hline CAVPO-PR \\
\hline LAa7055 \\
\hline LAa7051 \\
\hline BOMMO-LN \\
\hline HOMSA-LP \\
\hline NECRU-LN \\
\hline TYTSE-LN \\
\hline DAPPU-LN \\
\hline DOLMA-PI \\
\hline CAVPO-PR \\
\hline LAa 7055 \\
\hline LAa 7051 \\
\hline BOMMO-LN \\
\hline HOMSA-LP \\
\hline NECRU-LN \\
\hline TYTSE-LN \\
\hline DAPPU-LN \\
\hline DOLMA-PL \\
\hline CAVPO-PR \\
\hline LAa 7055 \\
\hline LAa 7051 \\
\hline BOMMO-LN \\
\hline
\end{tabular}

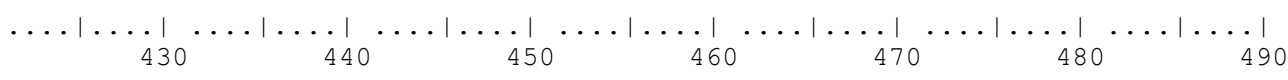
FTANKCFPCP SGG--CPQMG HYADRYPG-K TNDVGQKFYL DTGDASNFAR WRYKVSVTLS GKK-----VT FLAGKCAECG PDTSRCAIMG IRADEYYKFR NSSVQHVMYL QTTGKPPYWL YHYQIRMKLF KPRTSYKDVK FMQGKCSSCG PNGRDCAVMG FLAEEHKP-- AELINTTYFL RTQDHSPFCV YHYQVDIYLQ DGED--LELE FHRGECTSCG ADNLNCAKFG MDAALYPT-- RDRNYVHLLF DTDKDVPYIK YHYGIKVNLA YPSQAEAFVY PVSK----- CTRNECVCVG LNAKKYPK-- ----RGSFYV PVEAEAPYCN NNGKII---- -------FQESGCFPCP AKG--CPKMG HFADQYPG-K TNAVEQTFFL NTGASDNFTR WRYKVTVTLS GEKD----PS LEGE---TCN LSGLPNVWMG GEPSNHER-- --GVKGIFMV HTNSEAPFAK D-------- - - - - - ILNG---GCS SVG-PYAKMG GEPSNRGL-- --GVRGVYYL RTNAQSPFAR G-------- -------AQNN---QCS GGT---FNMG N--AVFGK-- --RGNGIYGL RTGSSWPF-- - - ------

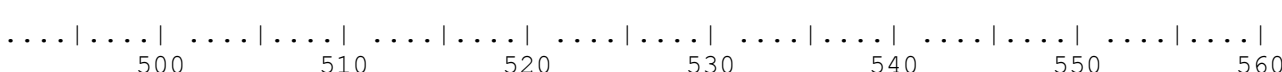
GHILVSLFGN KGNSKQYEIF KGTLK--PDS THSNEFDSDV DVGDLQMVKF IWYNNV---- --------I GTIEITLFGS KADELFHVQ- DKEIDLYHGA RYQYLVTTDK ELGEIKSVSL KWYSSSRFS- ---IFTKPKL GKFKLTLEHD FDEKFTVVVN EKYVRLIPGT VLTYTMISPY EFHLSDTITF YWTSSS-FT- ---FWNSHVF GTMRMSLYGT LGQLIDVTVA DKSHKFVHGT DSFFLFVDSF NVGNIQRVEL YWKYDGTLFN PCGLFCNDHI

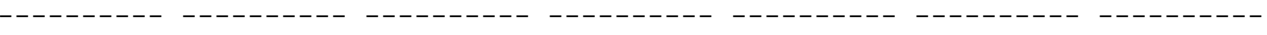
GNINVALLGK NGNSAQYQVF KGTLK--PDA SYTNSIDVEL NVGTIQKVTF LWKRSG---- --------I

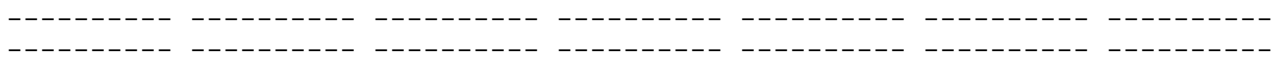

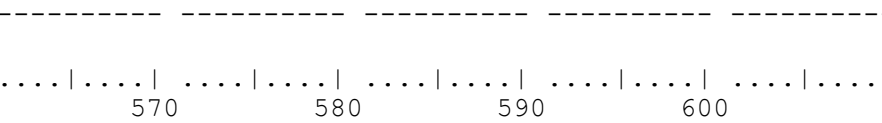

NPTLPRVGAS KTIVETN-VG KOFNFCSPET VREEVITTIT PC-

YVEYITVMPM NVIEASPRNA TDRVFCNKPD NGIASKTIAT FHRSNSCPR GIDKVRITPM ELIDKITQNS LIKTYYPKS- NPLAEMKETK FYLKDY--YVRSVEISEL NNYPESSRLE HTYKSCAVGA DYADMKDKTW AEFYPTACV

$\begin{array}{lllll}--------- & --------- & --------- & --------- & --------- \\ \text { SVSKPKMGAS RITVOSGKDG TKYNFCSSDI VOENVEOTLS PC------ }\end{array}$

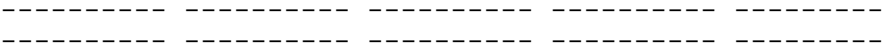

$--------$

Figura 15 - Alinhamento em ClustalW2 das lipases de Ae. aegypti, L-Aa7055 e L-Aa7051, com a lipase pancreática humana (HOMSA-LP), proteína 2 relacionada a lipase pancreática de porco da índia (Cavia porcellus /CAVPO-PR), fosfolipase A1 de vespa (Dolichovespula maculata /DOLMA-PHOSPA1), as lipases digestivas de Bombyx mori (BOMMO-LN), Tityus serrulatus (TYTSELN) e Nephilingis cruentata (NECRU-LN) e Daphnia pulex (DAPPU-LN). O pentapeptídeo G-X-S-X-G onde se encontra a Ser catálica e os demais resíduos envolvidos em catálise estão coloridos em amarelo: Ser 276; Asp 304; His 392. As regiões das alças $\beta 5, \beta 9$ e domínio tampa estão localizados entre os resíduos marcados em verde e nomeados abaixo.

Inicialmente, conferimos a presença dos resíduos catáliticos. Então analisamos a localização, tamanho e composição de aminoácidos das alças $\beta 5, \beta 9$ e domínio tampa. Os resíduos da tríade catalítica foram identificados no alinhamento nas posições: Ser 165, His 279 e Asp 193, tendo a LP humana como referência. A região da alça $\beta 5$ começa na posição 50 com os resíduos: His-Gly-Phe (HGF); a alça $\beta 9$ está localizada na posição 210 começando com os resíduos: His-Thr (HT) e o domínio tampa é definido por uma ponte dissulfeto localizada entre a Cys238 e Cys262.

O alinhamento permitiu a comparação das lipases digestivas do mosquito com lipases neutras que foram bem estudadas bioquimicamente e estruturalmente. As identidades obtidas foram de 32\% (L-Aa7051) e 34\% (L-Aa7055) com a LP 
humana; 32\% (L-Aa7051) e 33\% (L-Aa7055) com a PRLP2 de porco da índia (Cavia porcellus) que apresenta o domínio tampa reduzido (7 resíduos); 25\% (L-Aa7051) e 31\% (L-Aa7055) com a fosfolipase A1 (FLP A1) da vespa Dolichovespula maculata que apresenta a alça $\beta 9$ reduzida (14 resíduos), domínio tampa reduzido (9 resíduos) e não apresentas o domínio C-terminal.

Assim como outras lipases encontradas em insetos, as lipases do mosquito não apresentam a região C-terminal que é a região de ligação à colipase. A alça $\beta 5$ estava presente, com o mesmo número de resíduos encontrados na LP humana e nas lipases dos outros insetos. A região da alça $\beta 9$ da LP humana apresenta 21 resíduos de aminoácidos, as lipases neutras de Ae. aegypti fase larval e adulta apresentaram uma alça $\beta 9$ de 15 resíduos de aminoácidos, uma redução de 6 resíduos de aminoácidos.

O tamanho da região da tampa é extremamente reduzida nas lipases digestivas de insetos assim como as observadas para a PRLP2 e FLP A1, sendo de 9 resíduos para L-Aa7055 e 6 resíduos para L-Aa7051. A LP humana possui 25 resíduos de aminoácido em sua tampa.

O alinhamento, utilizando um alto número de sequências (139) foi utilizado para a construção de uma árvore filogenética (Figura 16). Conseguimos observar que a árvore se divide em dois grandes grupos (G), o primeiro composto por lipases pancreáticas e neutras (G-LP) e o segundo grande grupo composto por lipases gástricas e ácidas (G-LG). A árvore foi colapsada para mostrar apenas os ramos que apareceram com valores de "bootstrap" acima de 85\%. Dessa forma, foi possível observar a formação de subgrupos (SG) com alto suporte, geralmente acima de $90 \%$. 


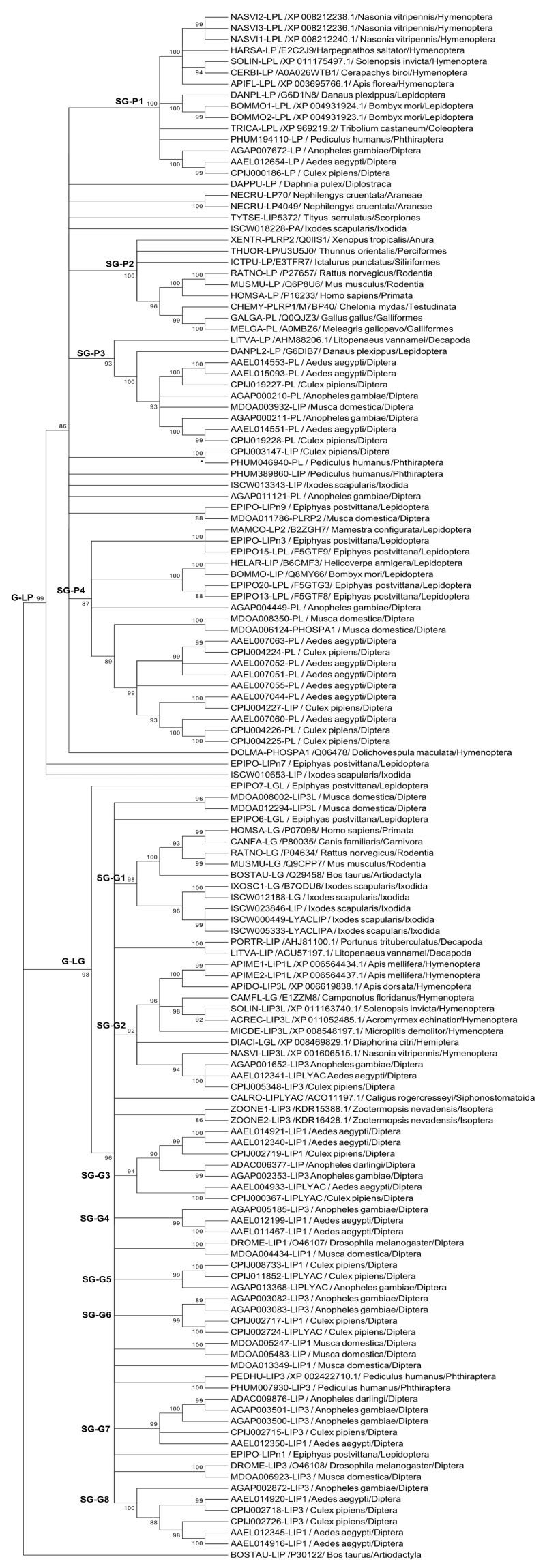


Figura 16 - Análise filogenética molecular utilizando o método de máxima verossimilhança (WHELAN e GOLDMAN, 2001). A árvore com o maior log de verossimilhança foi mostrada. A porcentagem de árvores em que determinado táxon associado foi agrupado está mostrado na ponta dos ramos. A árvore inicial foi obtida pelo método de Neighbor-Joining. A análise envolveu 139 sequências de aminoácidos e foram realizadas no MEGA6 (TAMURA et al., 2013). Os grupos foram identificados como G-LP (grupo das lipases neutras) e G-LG (grupo das lipases gástricas), e os subgrupos por SG-Px e SG-Gx (sendo x o número do grupo). As abreviaturas utilizadas na nomenclatura das sequências foram descritas na seção 3.8 , sendo nas sequências obtidas no VectorBase o próprio número de acesso. O tipo de lipase foi determinado após a abreviatura sendo LIP (lipase), LP (lipase pancreática), LPL (lipase pancreática like), PLRP (Proteína relacionada a lipase pancreática), LG (lipase gástrica), LGL (lipase gástrica like) e LIPLYAC (Lipase ácida lisossomal). O nome do animal (gênero e espécie) foi anotado seguido da ordem ao qual pertence.

Dentre as lipases pancreáticas (G-LP) observamos 4 subgrupos. O Subgrupo P1 (SG-P1) é formado basicamente por lipases de insetos sendo dividido em três ramos com alto suporte que contém lipases de Hymenoptera, Lepidoptera e Diptera majoritariamente, o subgrupo 2 (SG-P2) é onde encontramos as lipases de vertebrados, entre os subgrupos 1 e 2 encontramos as sequências de três representantes da classe Arachinida e um representante do subfilo Crustacea (Figura 17), o subgrupo 3 (SG-P3) é formado majoritariamente por espécies de Diptera, mas também apresenta a sequência de Litopenaeus vannamei (Malacostraca: Decapoda) e apresenta dois grupos bem suportados com sequências de Ae. aegypti e Culex pipiens em ambos. Essa separação dentro de Diptera indica a ocorrência de duplicações gênicas (Figura 18). O subgrupo 4 (SG-P4) apresenta pelo menos quatro grupos bem suportados, 2 constituídos por lipases de Lepidoptera e 2 constituídos por lipases de Diptera. Nos dois grupos podemos observar a ocorrência de duplicações gênicas tanto para Ae. aegypti e Culex pipiens quanto para Epiphyas postivitana. As lipases digestivas descritas para insetos se aguparam no SG-P4 (Figura 19), onde encontramos as duas lipases em estudo do mosquito Ae. aegypti (L-Aa7051 e L-Aa7055), a lipase isolada em Bombyx mori (Q8MY66), algumas que tiveram a expressão gênica medida no intestino como a das lagartas Epiphyas postvittana (F5GTF8), Mamestra configurata (B2ZGH7) e Helicoverpa armigera (B6CMF3) (CAMPBELL et al., 2008; MARKWICK et al., 2011; PONNUVEL et al., 2003; TOPRAK et al., 2008;). 


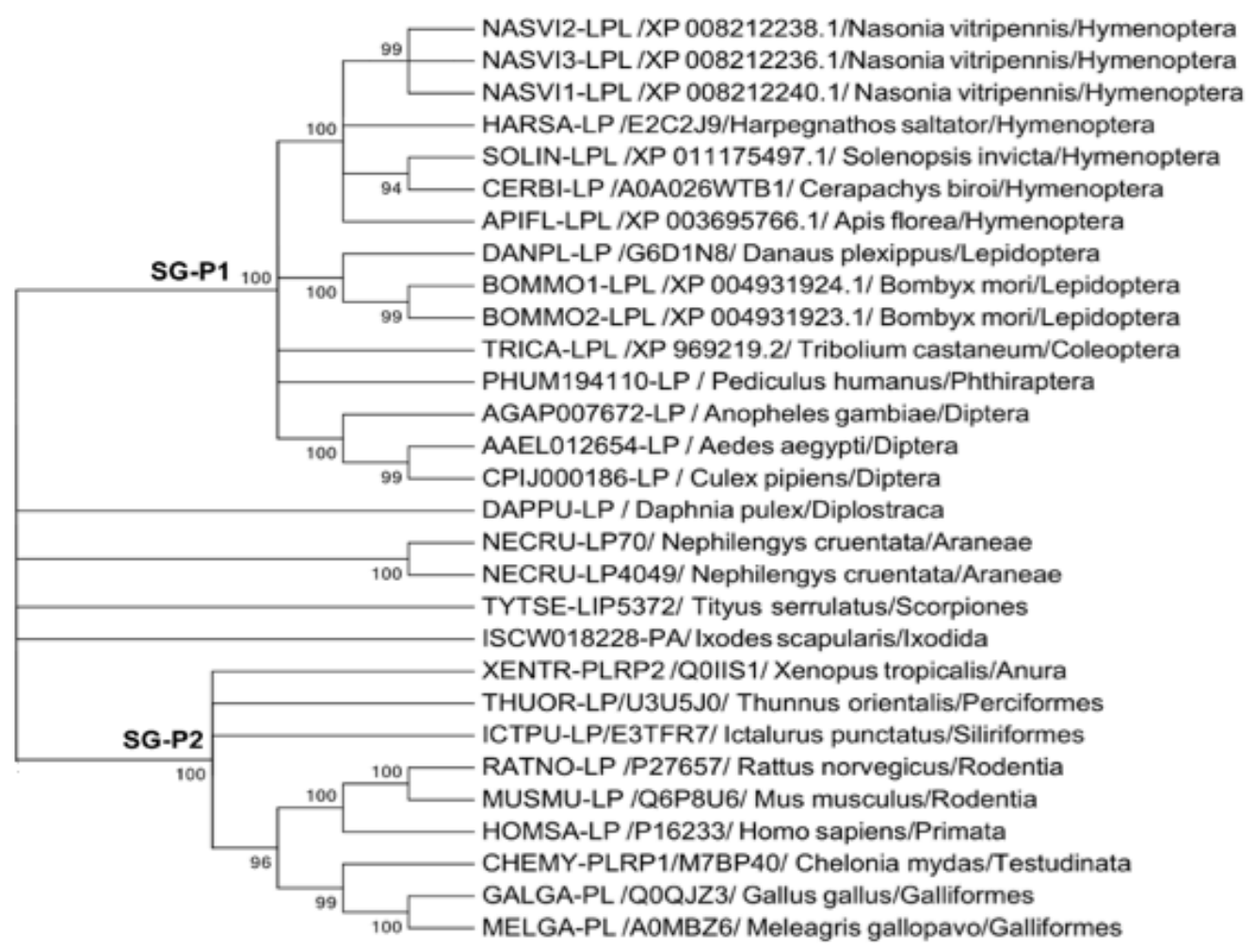

Figura 17 - Subgrupo 1 (SG-P1) e 2 (SG-P2) das lipases neutras. As sequências do SGP1 são compostas, em sua maioria, por insetos das ordens Hymenoptera, Lepidoptera e Diptera. No SG-P2 estão agrupadas as lipases neutras de vertebrados.

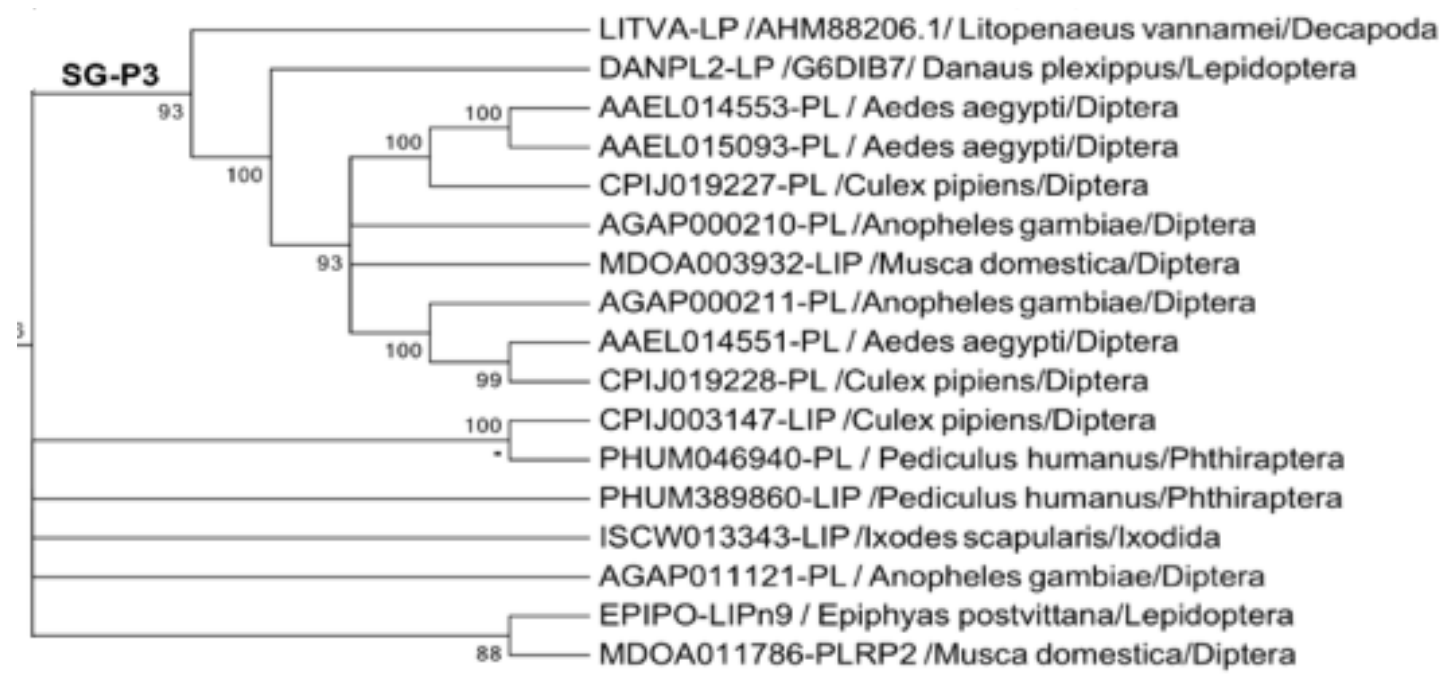

Figura 18 - Subgrupo 3 (SG-P3) das lipases neutras. Esse subgrupo é composto majoritariamente por sequências de Diptera 


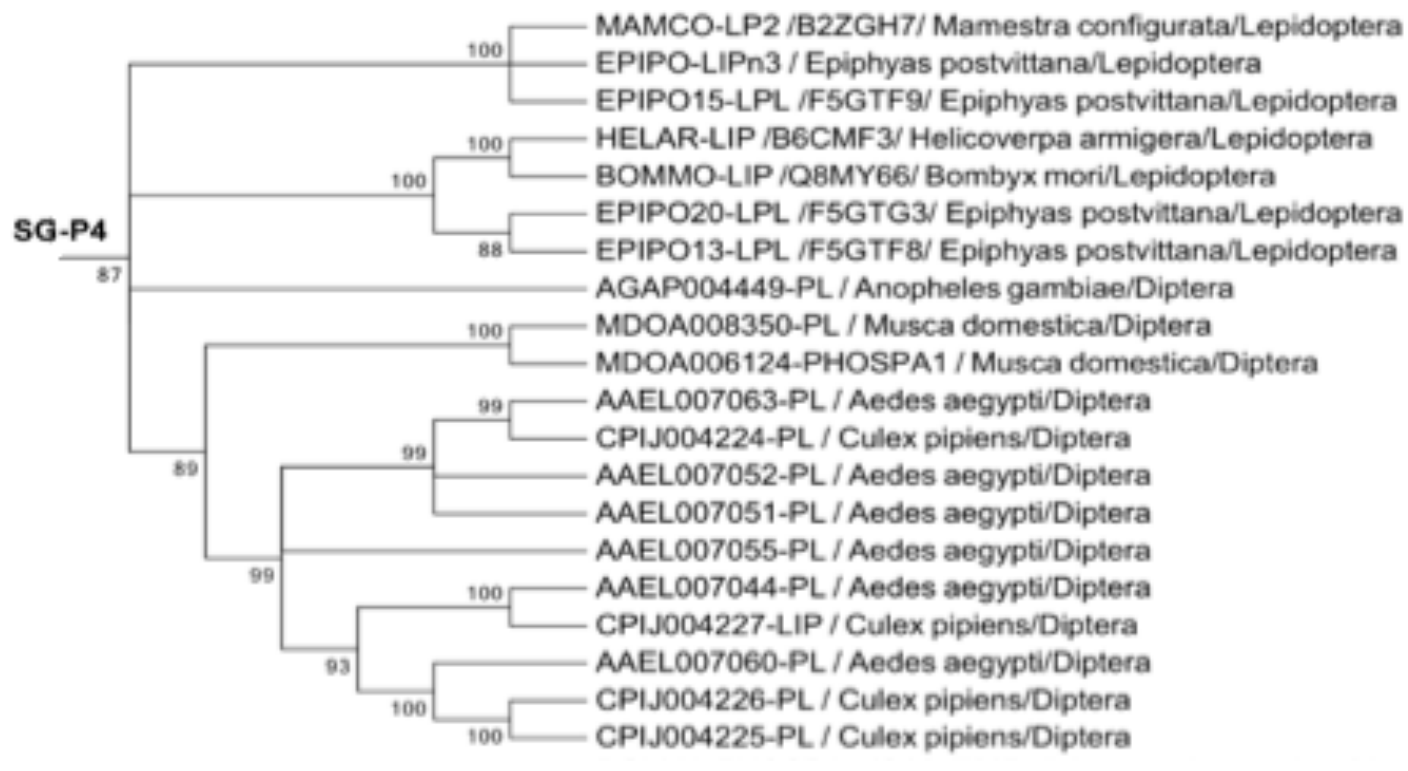

Figura 19 - Subgrupo 4 das lipases neutras (SG-P4). As lipases de insetos descritas como digestivas na literatura se agruparam majoritariamente nesse subgrupo. $O$ subgrupo se divide basicamente em três grupos, dois formados por lipases de Lepidoptera e o terceiro por lipases de Diptera.

Algumas estruturas consideradas importantes para a atividade $\mathrm{e}$ especificidade sobre substratos foram identificadas nas sequências das lipases neutras analisadas. As lipases de todos os subgrupos (SG-P1 a SG-P4) apresentaram a alça $\beta 5$ conservada contendo 10 resíduos de aminoácidos, a alça $\beta 9$ das sequências encontradas nos subgrupos SG-P1, SG-P2 e SG-P3 apresentam pelo menos 20 resíduos de aminoácido sendo parecidas com a lipase humana, enquanto as lipases do subgrupo SG-P4 apresentaram apenas 15 resíduos de aminoácidos.

O domínio tampa, que nas lipases neutras de vertebrados apresentam 25 resíduos de aminoácidos, foi o que apresentou maiores diferenças entre os subgrupos. As sequências do subgrupo SG-P1 apresentaram 29 resíduos de aminoácidos no domínio tampa, as do subgrupo SG-P2 apresentaram 24 resíduos de aminoácidos nesse domínio, as do subgrupo SG-P3 apresentaram 25 resíduos de aminoácidos. As lipases do subgrupo SG-P4, onde se encontram as lipases digestivas de Ae. aegypti (L-Aa7051 e L-Aa7055) e a maioria das outras lipases digestivas caracterizadas em outros insetos, apresentaram o domínio tampa bastante reduzido com variação de 5 a 10 resíduos de aminoácido, sendo que a maior parte das sequências apresentaram 9 resíduos. 
As lipases gástricas apresentam pelo menos 8 subgrupos, subgrupo 1 (SGG1) composto por lipases de vertebrados (Figura 20), subgrupo 2 (SG-G2) composto basicamente por sequências de Hymenoptera com um pequeno grupo bem suportado de Diptera (Figura 21), os grupos 3 (SG-G3) ao 8 (SG-G8) são compostos basicamente de sequência de Diptera com evidências de um grande número de duplicações gênicas.

O alinhamento de algumas sequências de lipases ácidas de Ae. aegypti (encontradas no SG-G3 e SG-G4) com a LG humana (P07098) permitiu a identificação dos motivos conservados. As sequências do mosquito possuem tamanho similar a humana com aproximadamente 400 resíduos de aminoácidos, as identidades encontradas foram: 38\% (AAEL012341); 37\% (AAEL014921); 37\% (AAEL012340) e 35\% (AAEL004933).

A tríade catalítica que na LG humana é formada pelos resíduos Ser 153, His 353 e Asp 324, se mostrou bem conservada no alinhamento com as sequências de mosquito, a Ser 153 catalítica está localizada na sequência consenso formada pelo pentapeptídeo GXSXG que também é conservado nas lipases ácidas do mosquito. $A$ região do domínio capa onde é encontrado o domínio tampa em lipases ácidas também é conservada, as lipases de insetos possuem de 3 a 4 resíduos de aminoácidos a mais nessa região. A ponte dissulfeto também é conservada, sendo aumentada em um resíduo na lipase AAEL012341 (10 resíduos), esse mesmo aumento é observado nas lipases ácidas da lagarta Epiphyas postvittana (CHRISTELLER et al., 2010). O tamanho das regiões relacionadas as estruturas das lipases ácidas encontradas no mosquito Ae. aegypti é bastante parecida com a observada na LG humana, o que segue as comparações descritas na literatura. Por esse motivo se estima que essas lipases atuem especificamente sobre TAGs. Contudo, não se sabe qual seria a implicação das mudanças nos resíduos de aminoácidos na atividade da enzima. 


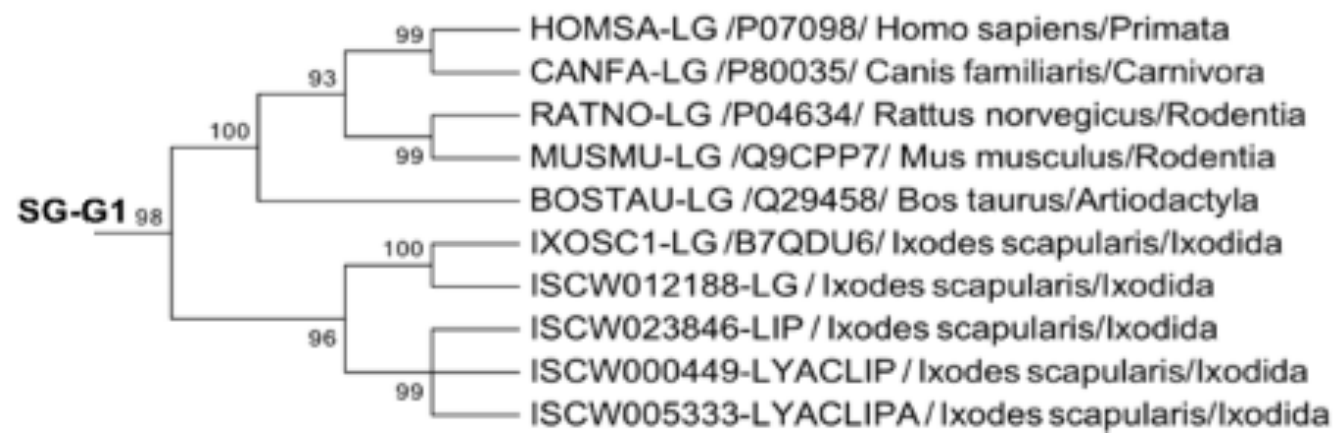

Figura 20 - Subgrupo 1 (SG-G1), onde estão agrupadas as lipases ácidas de vertebrados.

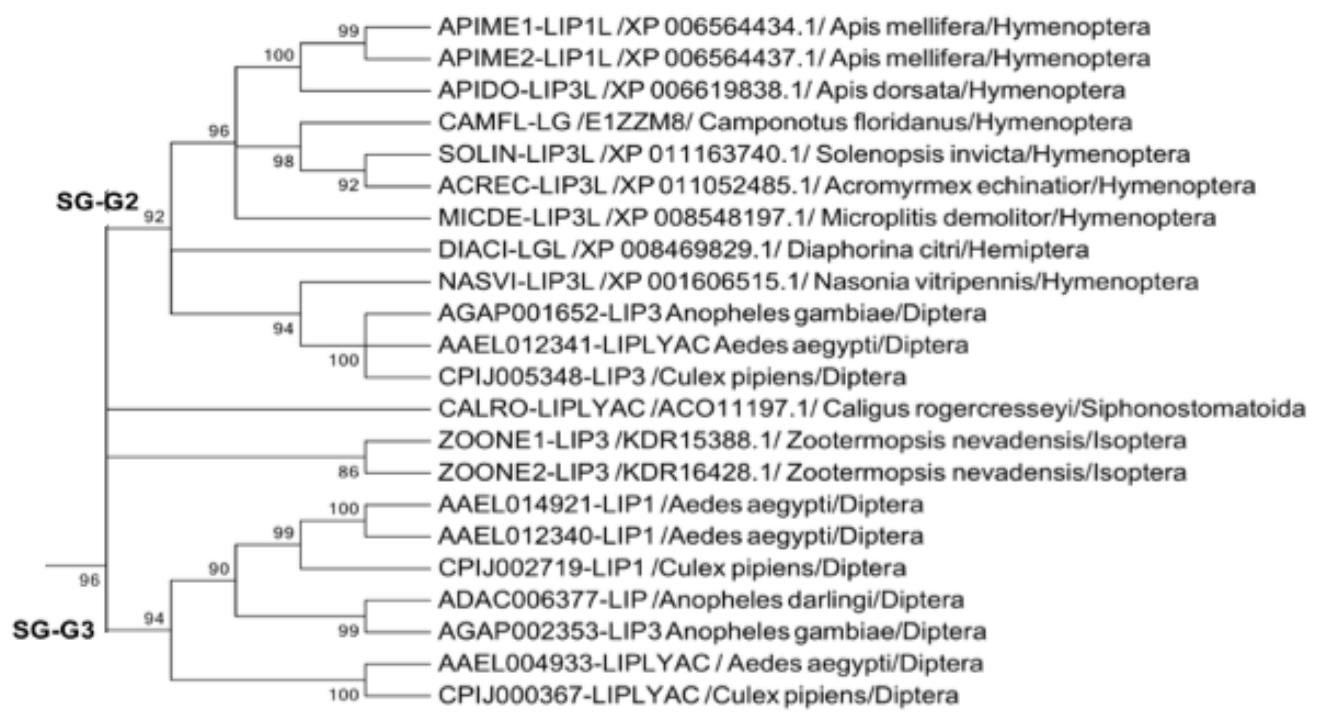

Figura 21 - Subgrupo 2 (SG-G2) e 3 (SG-G3) das lipases ácidas. As lipases analisadas por alinhamento estão representadas nesses dois grupos.

\subsection{Determinação das lipases envolvidas na digestão em diferentes fases do desenvolvimento do mosquito Ae. aegypti}

As 2 sequências de lipase pré-selecionadas por RT-PCR semi-quantitativo foram submetidas a análise por qPCR para avaliação de sua expressão. A expressão da lipase L-Aa7055 foi comparada entre carcaça e intestino médio de fêmeas adultas alimentadas com sangue e sacarose, onde foi possível observar valores de expressão aumentados em 48 vezes no intestino de fêmeas alimentadas com sangue e 58 vezes em fêmeas alimentadas com sacarose (Figura 22A). Os altos níveis de expressão observados no intestino médio evidenciam sua presença nesse tecido atuando no processo digestivo, confirmando o observado em RT-PCR. No entanto, o experimento de RT-PCR indicava uma maior amplificação da lipase na 
dieta com sacarose, quando comparada com a sanguínea (Figura 9). O experimento de qPCR mostrou que a diferença de expressão é estatisticamente insignificante.

Quando a expressão foi testada no intestino médio de mosquitos adultos em comparação com os intestinos médio de larvas $L 4$, observamos que a expressão no intestino de fêmeas adultas era 260 vezes maior na alimentação com sangue e 316 vezes em alimentação com sacarose (Figura 22B). Com esses dados podemos afirmar que o gene L-Aa7055 codifica uma lipase digestiva expressa na fase adulta do mosquito fêmea tanto na alimentação em sacarose como em sangue, esses dados confirmam o que havia sido observado no RT-PCR.

A análise da expressão do gene L-Aa7051 evidenciou uma maior quantidade de mRNA dessa lipase no intestino na fase larval do mosquito Ae. aegypti. Quando a expressão do gene foi comparada entre tecidos, intestino e carcaça, foi possível observar a presença 351 vezes maior deste mRNA no intestino (Figura 23A). Para verificar que a expressão do gene era essencialmente encontrada no intestino de larvas a quantificação de L-Aa7051 foi testada no intestino de fêmeas adultas alimentadas com sangue e sacarose. Esta comparação se mostrou 42.000 vezes maior no intestino de larvas $L 4$, sendo a lipase L-Aa7051 codificada exclusivamente no intestino médio da fase larval (Figura 23B). 
A)

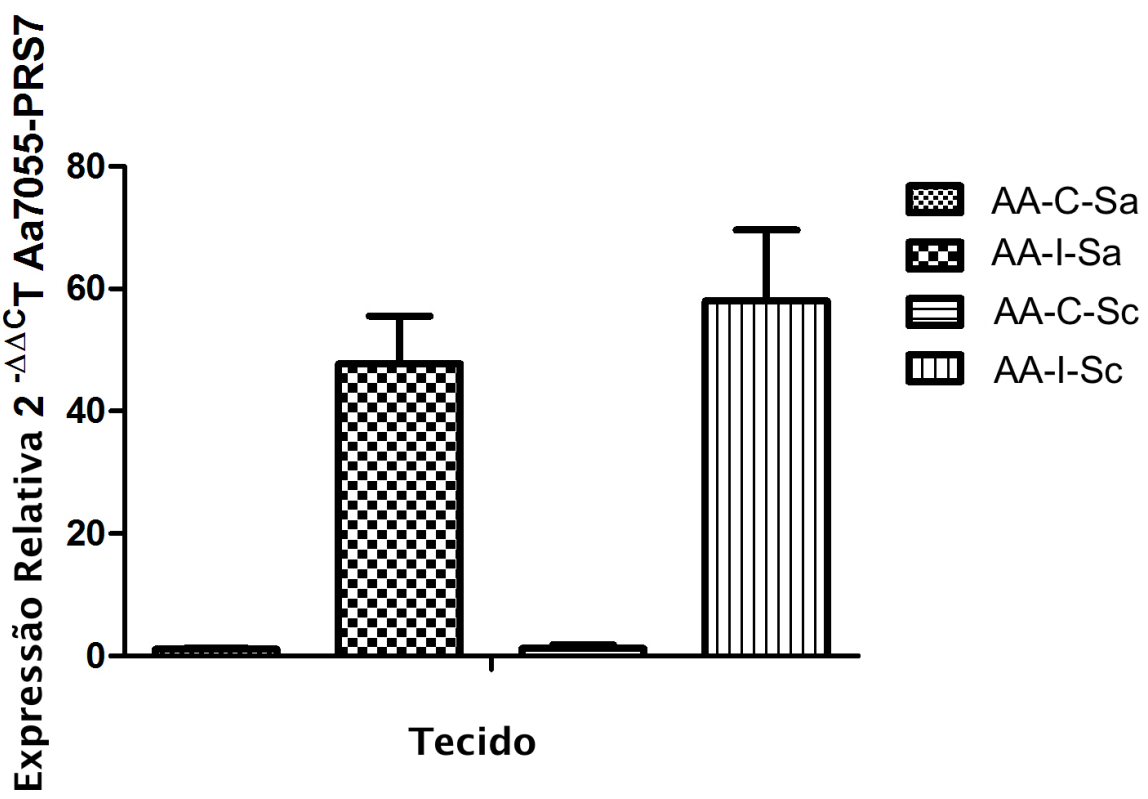

B)

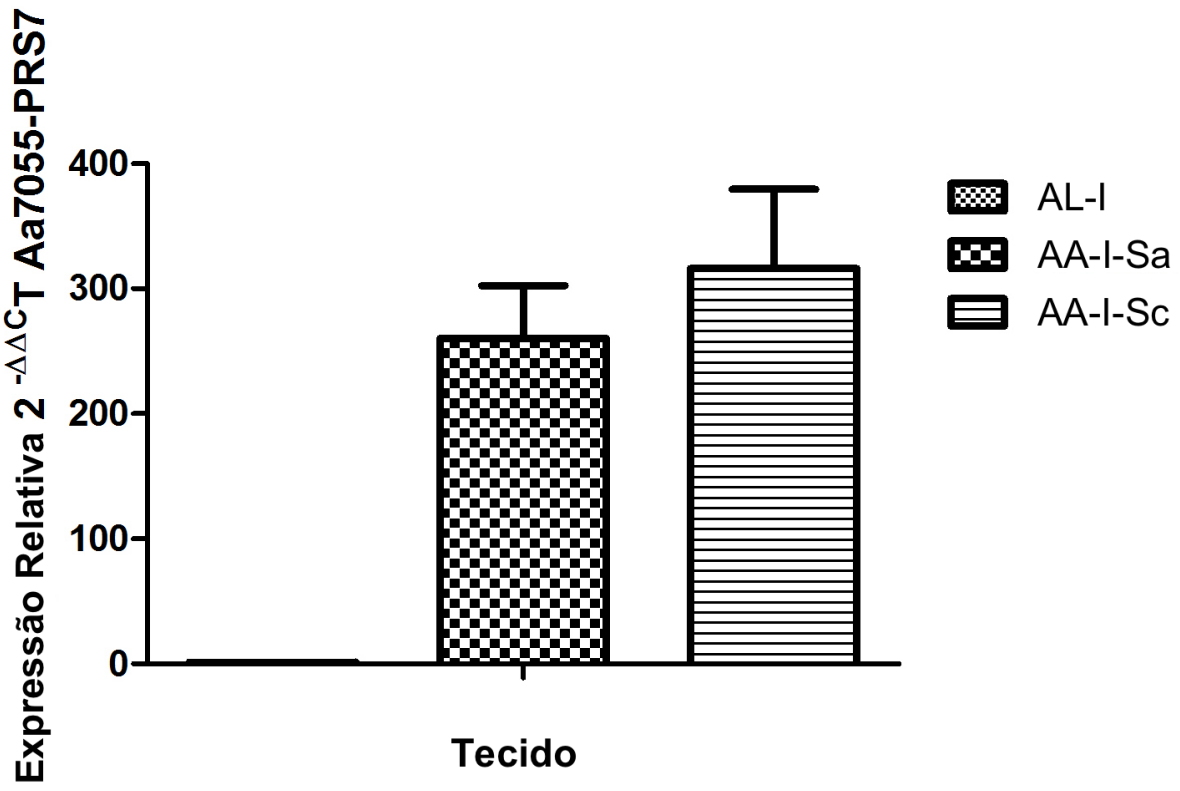

Figura 22 - Análise dos dados obtidos em qPCR para a expressão da lipase L-Aa7055 em adultos e larvas de Ae. aegypti. A) Análise de amostras a partir de tecidos isolados de fêmeas adultas do mosquito Ae. aegypti ingurgitadas com sangue: carcaça (AA-C-Sa) e intestino (AA-I-Sa) e ingurgitadas com sacarose carcaça (AA-C-Sc) e intestino (AA-I-Sc). B) Intestino médio de larvas de Ae. aegypti (AL-I), fêmeas adultas do mosquito Ae. aegypti ingurgitadas com sangue (AA$\mathrm{I}-\mathrm{Sa}$ ) e ingurgitadas com sacarose (AA-I-Sc). 
A)

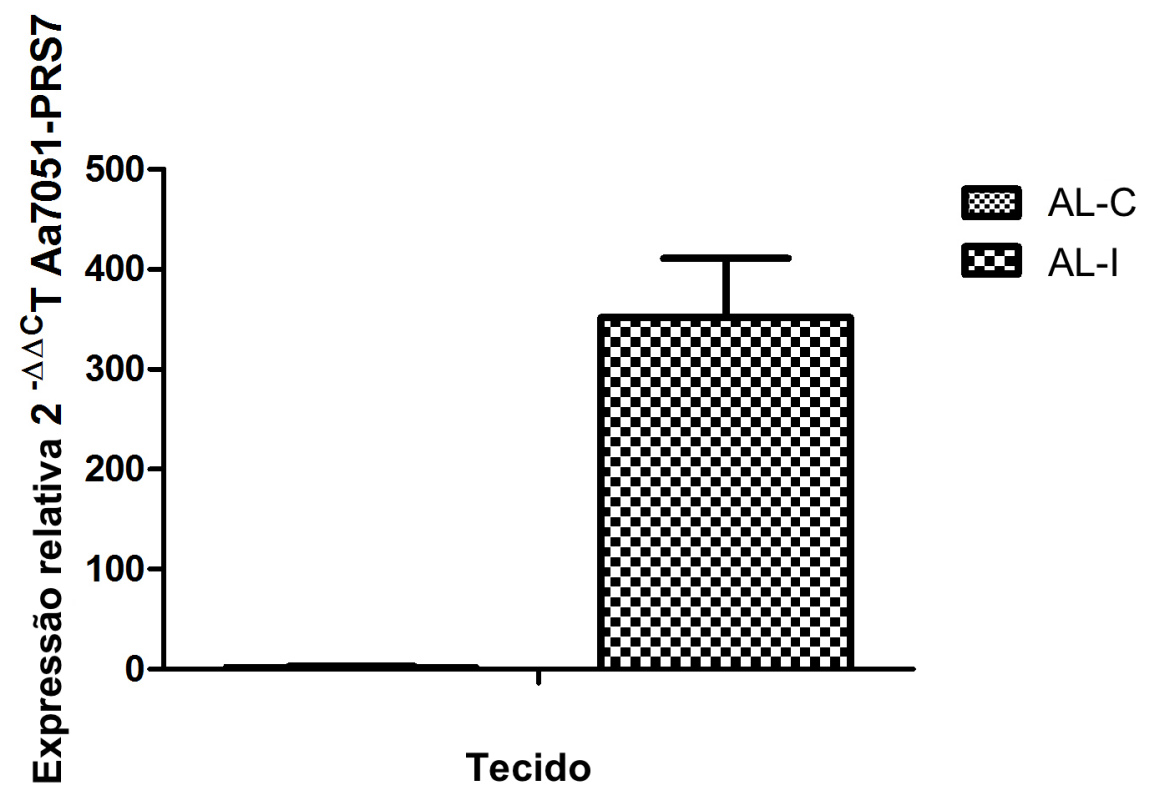

B)

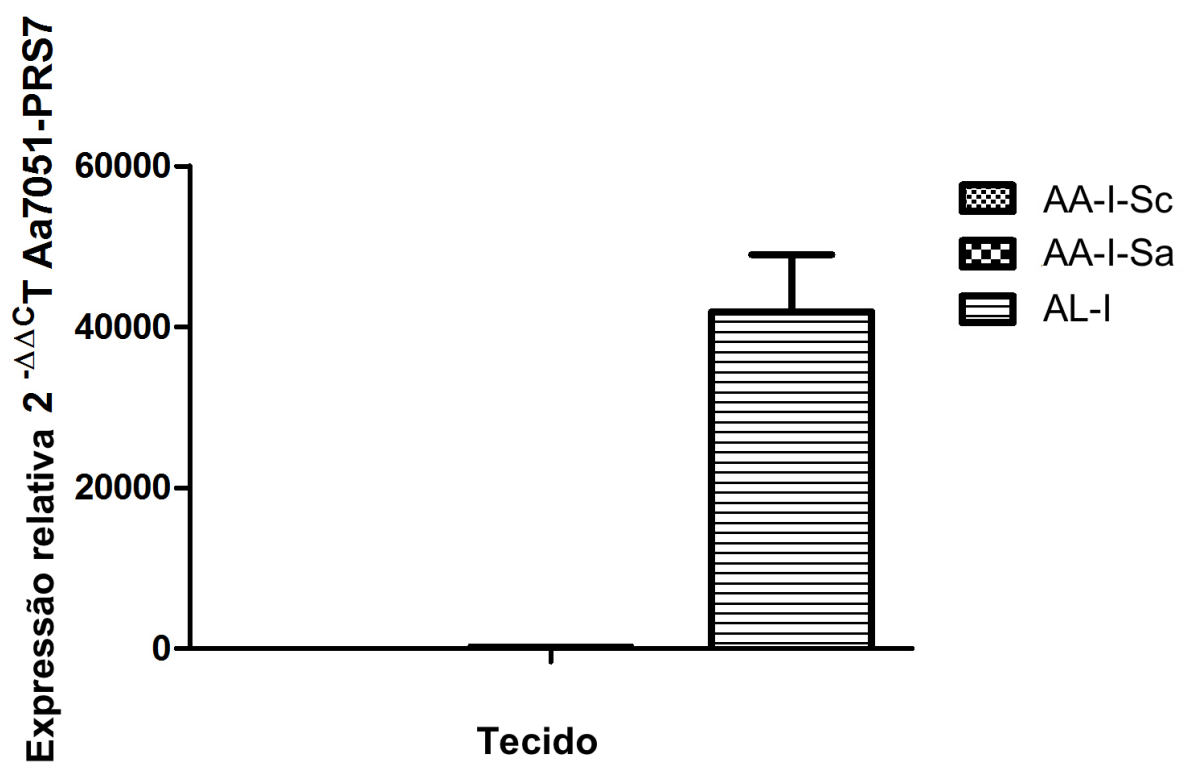

Figura 23 - Análise dos dados obtidos em qPCR para a expressão da lipase L-Aa7051 em larvas e adultos de Ae. aegypti. A) Larvas de Ae. aegypti, carcaça (AL-C) e Intestino médio (AL-I). B) Intestino médio de fêmeas adultas do mosquito $A e$. aegypti ingurgitadas com sacarose (AA-I-Sc), ingurgitadas com sangue (AA-I$\mathrm{Sa})$ e intestino médio de larvas (AL-I).

A amplificação da lipase L-Aa7055 foi obtida por RT-PCR. O experimento foi realizado para verificar a expressão do gene em três diferentes condições: período de jejum, na alimentação com sacarose e em diversos pontos após o repasto sanguíneo. 
O experimento tinha como objetivo verificar em que momento ocorria o aumento nos níveis de transcrito da lipase digestiva L-Aa7055. Sabe-se pela literatura que as enzimas digestivas do mosquito $A e$. aegypti exibem dois comportamentos principais de expressão, prévia e tardia, sendo a expressão da maioria das enzimas tardia com pico entre 24 e 48 horas (DANA et al., 2005). Entretanto, o pico de atividade de lipase é descrito em 15 horas o que indica para um perfil de expressão prévio (GEERING; FREYVOGEL, 1975).

Os resultados obtidos (Figura 24) mostraram que a lipase digestiva de Ae. aegypti apresenta amplificação em todas as condições testadas, incluindo no período de jejum. Por ser o RT-PCR uma metodologia semi-quantitativa, não consideramos a intensidade das bandas um indicativo de nível de expressão.

Não conseguimos identificar por proteoma e espectrometria de massa (Orbitrap) a presença de nenhuma lipase ou esterase em frações cromatográficas enriquecidas em atividade sobre substratos de lipase proveniente do homogeneizado de intestino médio do mosquito. A análise foi realizada na fração cromatográfica onde encontramos o pico de atividade de lipase com o substrato butirato.

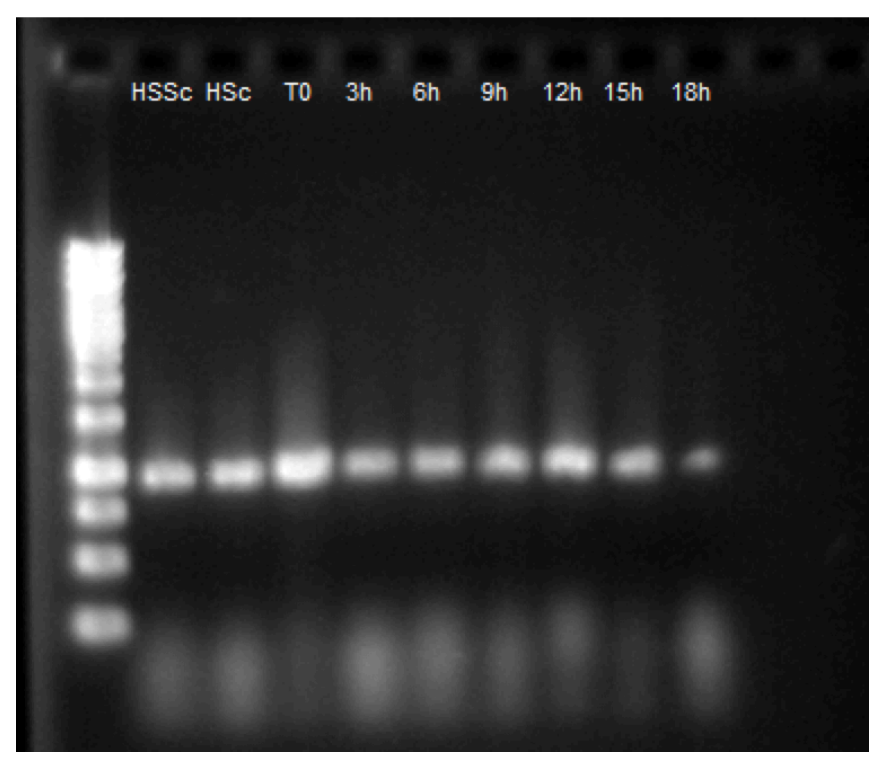

Figura 24 - Amplificação do gene de lipase AAEL705500 no intestino médio de fêmeas adultas do mosquito Ae. aegypti, cepa Higgs. Mosquitos sem alimentação prévia com sacarose (HSSc), mosquitos mantidos em sacarose (HSc), mosquitos dissecados $3,6,9,12,15$ e 18 horas após o repasto sanguíneo. Esse experimento norteou os períodos pós-alimentação para as análises de qPCR. 


\subsection{Expressão da lipase digestiva (L-Aa7055) na infecção por $P$. gallinaceum}

Análises por qPCR foram realizadas para detectar mudanças nos níveis de expressão da lipase digestiva (L-Aa7055) na pré-infecção e durante a infecção por $P$. gallinaceum.

No primeiro ciclo gonotrófico, os animais foram submetidos a alimentação com sangue infectado por $P$. gallinaceum. Houve variação na expressão da lipase em 15 horas, o teste estatístico utilizado foi o teste $U$ de Mann Whitney Pvalue: 0,0315; $P<0,05$, em 18 horas após a alimentação não foi encontrada variação Pvalue: 0,2345; $p<0,05$ em teste $U$ de Mann Whitney (Figura 25A). Não foi possível comparar os valores de amplificação obtidos 12 horas após a alimentação, pois foram observadas variações no gene constitutivo PRS7 o que impediu a normalização dos dados.

A variação da expressão também foi verificada no segundo ciclo gonotrófico, em mosquitos previamente infectados por $P$. gallinaceum. Foi possível observar, nos animais infectados, uma redução do nível de expressão da lipase estatisticamente significativo em 18 horas após a alimentação, Pvalue: 0,0214; $P<0,05$ em teste $U$ de Mann Whitney. Não foram observadas mudanças estatisticamente significativas na expressão da lipase após a infecção: em 12 horas, Pvalue: 0,2224; $P<0,05$ e em 15 horas, Pvalue: 0,8633; $P<0,05$ em teste $U$ de Mann Whitney (Figura 25B). 
A)

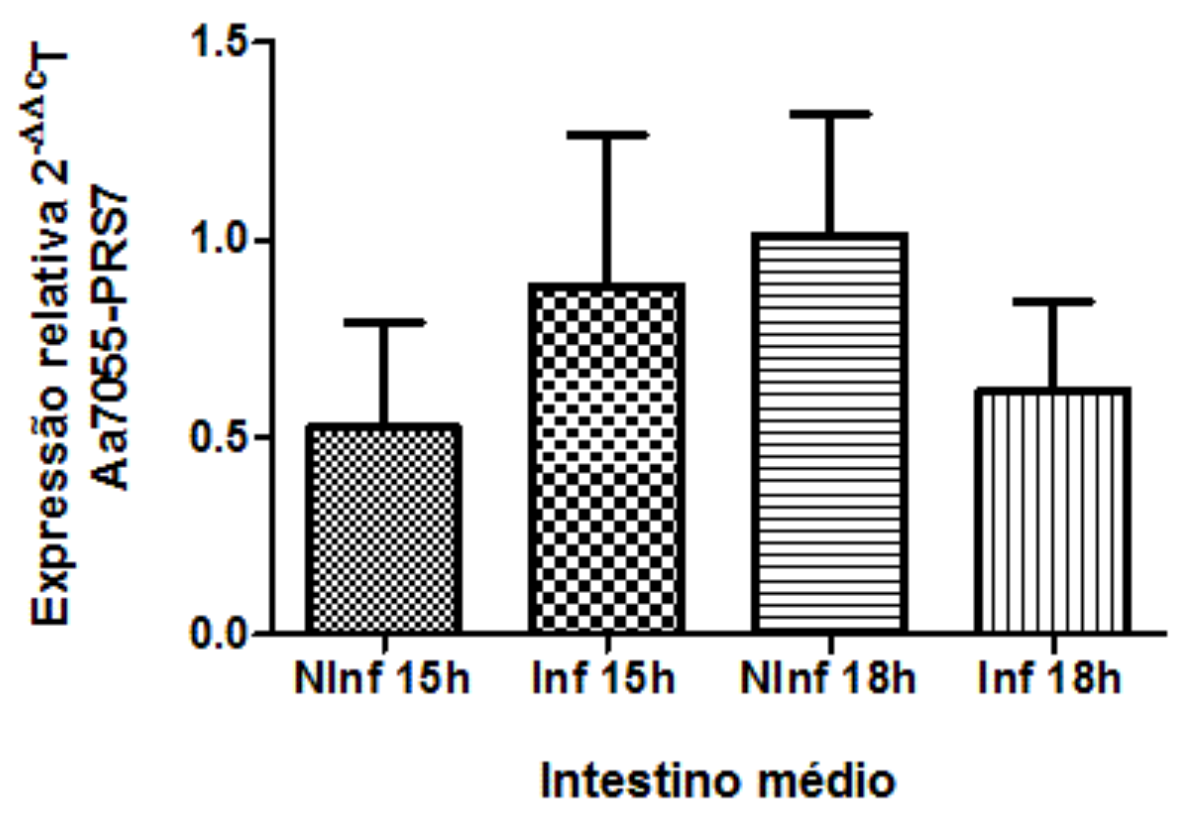

B)

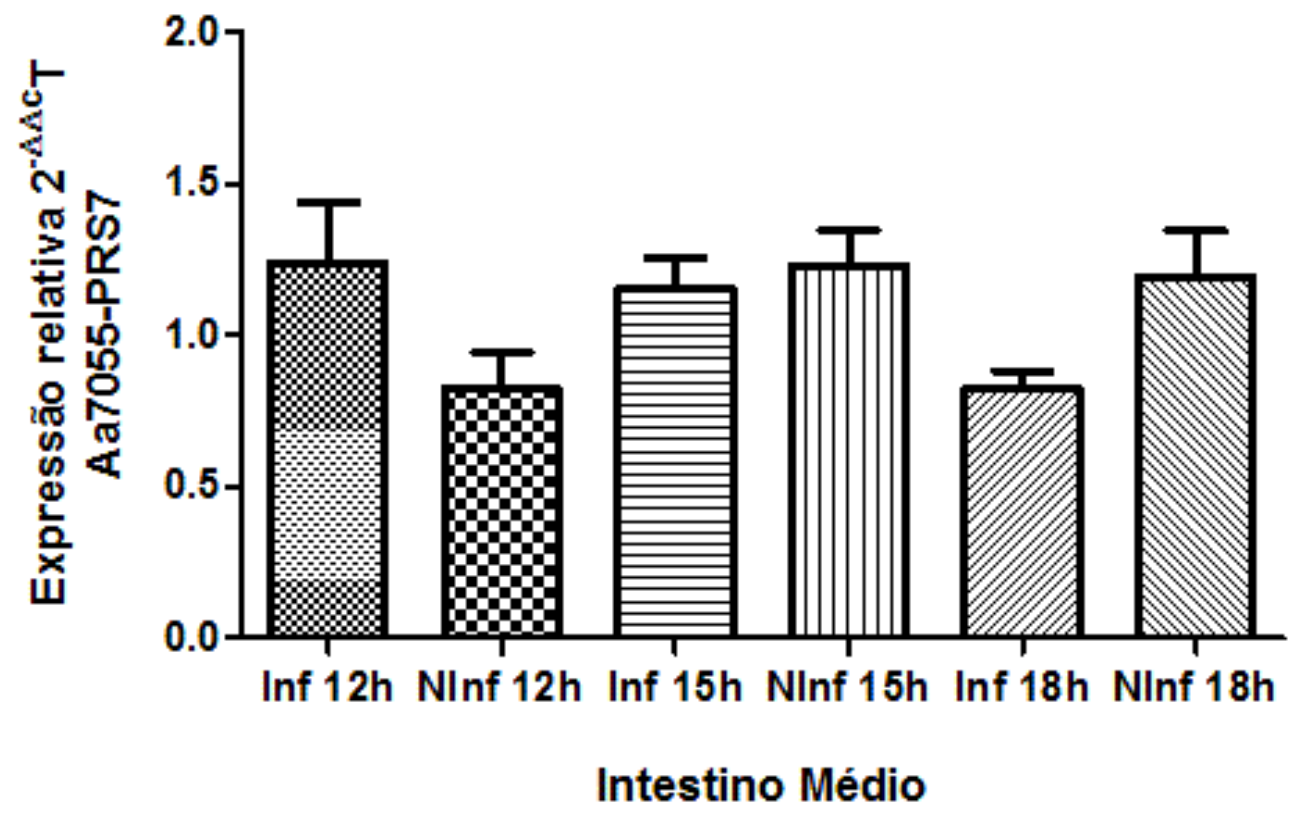

Figura 25 - Análise dos dados obtidos em qPCR para a expressão da lipase L-Aa7055 em Ae. aegypti adulto. A) $1^{\circ}$ ciclo gonotrófico, alimentação de animais sadios com sangue infectado por Plasmodium gallinaceum (Inf); B) $2^{\circ}$ ciclo gonotrófico, alimentação de animais infectados por Plasmodium gallinaceum (Inf) com sangue não infectado. As análises foram realizadas a partir de amostras de intestinos médio de fêmeas adultas do mosquito Ae. aegypti. Os controles não infectados (NInf) foram submetidos as mesmas condições que os infectados. O tempo após dissecção está indicado ao lado da condição do lote (Inf ou NInf). As barras correspondem ao desvio padrão encontrado em cada análise. 


\subsection{Expressão da lipase digestiva (L-Aa7055) na infecção por DENV2}

As análises da expressão da lipase L-Aa7055 também foram realizadas no intestino médio de animais infectados por DENV2. Não observamos variação estatisticamente significativa da expressão da lipase após a alimentação, em 12 horas, Pvalue: 0,1320; 15 horas, Pvalue: 0,5887 e 18 horas, Pvalue: 0,4848. Sendo $\mathrm{P}<0,05$ em teste $U$ de Mann Whitney (Figura 26).

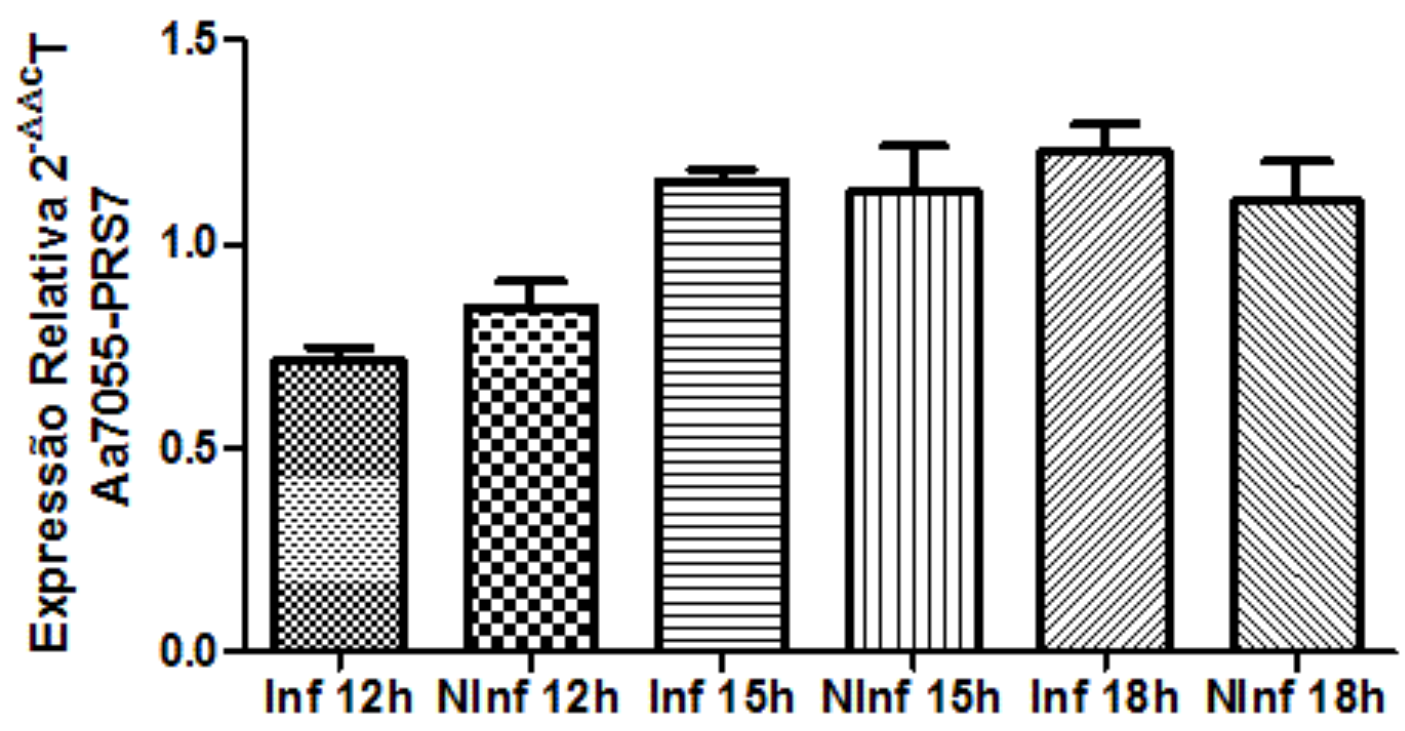

Figura 26 - Análise dos dados obtidos em qPCR para a expressão da lipase L-Aa7055 no intestino médio de $A e$. aegypti adulto. Foram utilizados animais em seu $2^{\circ}$ ciclo gonotrófico, previamente infectados com DENV2 (Inf), que foram alimentados com sangue não infectado. Os controles não infectados (NInf) foram submetidos as mesmas condições que os infectados. O tempo após dissecção está indicado ao lado da condição do lote (Inf ou NInf).

\subsection{Clonagem e expressão das lipases digestivas presentes no intestino médio de fêmeas adultas (L-Aa7055) e larvas (L-Aa7051)}

\subsubsection{Expressão das lipases L-Aa7055 e L-Aa7051 em vetor pAE}

Após a ligação dos insertos L-Aa7055 e L-Aa7051 ao vetor pAE obtivemos a formação de diversas colônias que foram positivas, em PCR de colônia, para os plasmídeos desejados. Os plasmídeos obtidos foram sequenciados e suas sequências foram alinhadas para identificação de possíveis mutações ou deleções, sendo escolhidos os clones estruturalmente conservados. 
Foram feitas transformações de 3 linhagens bacterianas BL21(DE3), Origami(DE3) (Figura 27) e BL21 Star (DE3) pLysS (Figura 28) com os plasmídeos obtidos para L-Aa7055 e L-Aa7051. Entretanto, não foi observada a indução da expressão de lipase nestes transformantes.

A)

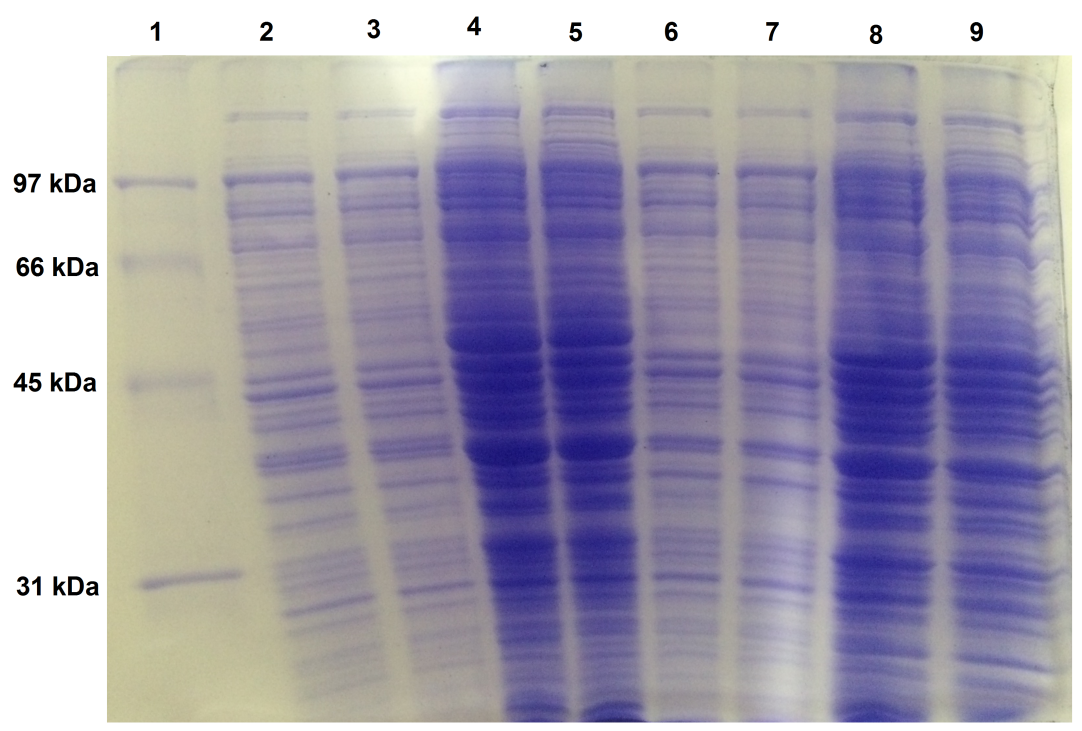

B)

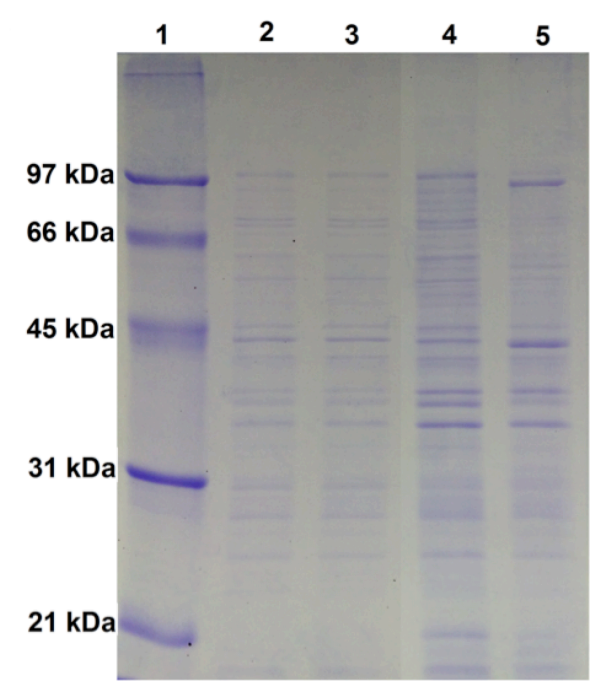

C)

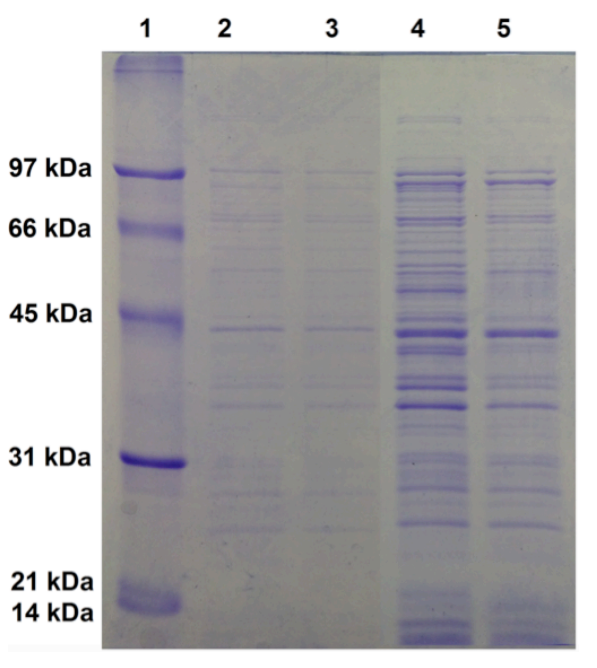

Figura 27 - Expressão das lipases L-Aa7055 e L-Aa7051. Gel de SDS-PAGE 12\% corado com Coomassie do perfil de expressão proteica encontrado em células $E$. coli BL21(DE3). A) transformação com o vetor pAE L-Aa7055 (bandas 2 a 5), (1) Padrão de massa molecular, (2) não induzido tempo 0 , (3) induzido tempo 0 , (4) não induzido tempo 13 horas e (5) induzido tempo 13 horas. Células transformadas com o vetor pAE L-Aa7051 (bandas 6 a 9), (6) não induzido tempo 0, (7) induzido tempo 0, (8) não induzido tempo 13 horas e (9) induzido tempo 13 horas. Perfil de expressão proteica encontrada em células Origami(DE3): B) transformação com vetor pAE L-Aa7055, (1) Padrão de massa molecular, (2) não induzido tempo 0, (3) induzido tempo 0, (4) não induzido tempo 10 horas e (5) induzido tempo 10 horas; C) Células 
transformadas com o vetor pAE L-Aa7051, (1) Padrão de massa molecular, (2) não induzido tempo 0, (3) induzido tempo 0, (4) não induzido tempo 10 horas e (5) induzido tempo 10 horas.

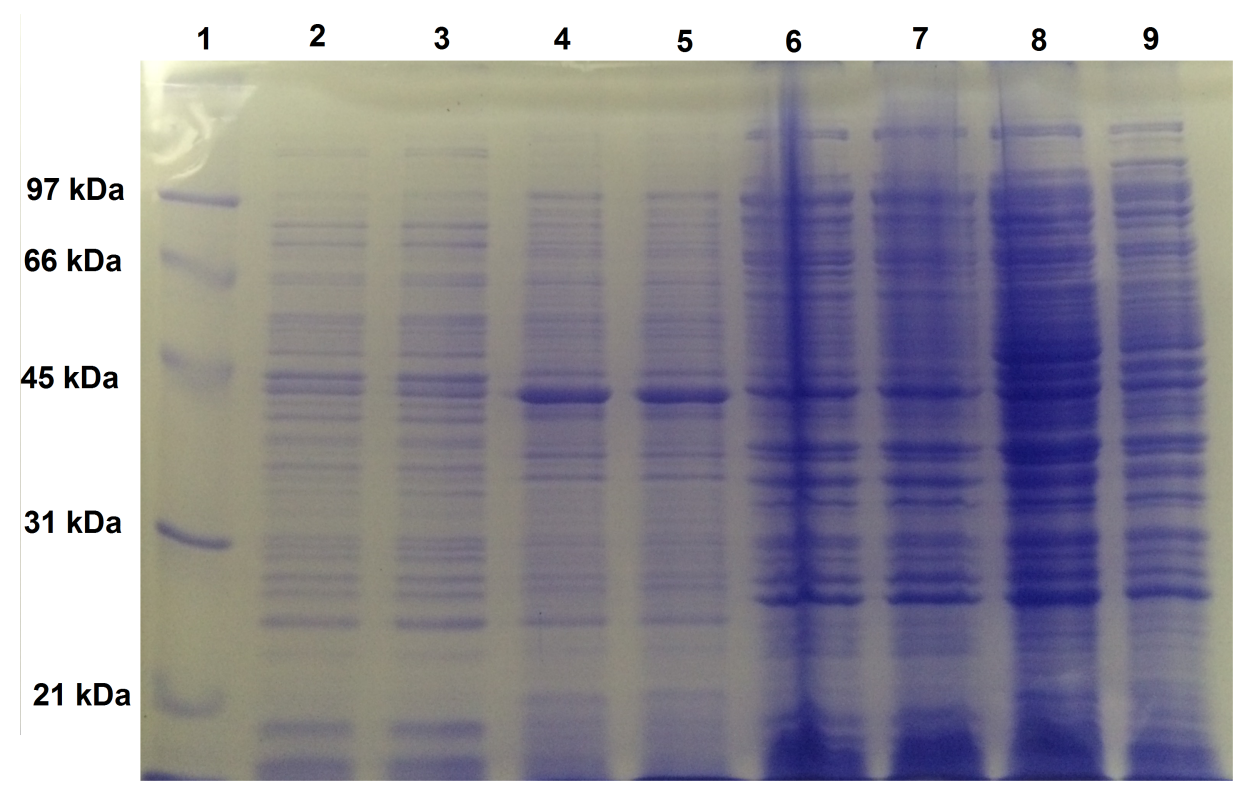

Figura 28 - Expressão das lipases L-Aa7055 e L-Aa7051. Gel de SDS-PAGE 12\% corado com Coomassie de amostras da indução do perfil de expressão proteica encontrado em células BL21 Star (DE3)pLysS. (1) Padrão de massa molecular, bandas de 2 a 5 transformação com vetor pAE L-Aa7055, (2) não induzido tempo 0, (3) induzido tempo 0, (4) não induzido tempo 13 horas e (5) induzido tempo 10 horas. Bandas de 6 a 9 células transformadas com o vetor pAE L-Aa7051, (6) não induzido tempo 0, (7) induzido tempo 0, (8) não induzido tempo 13 horas e (9) induzido tempo 13 horas.

\subsubsection{Expressão da lipase L-Aa7055 em vetor pOP}

Alternativamente, o inserto L-Aa7055 foi clonado em vetor pOP gentilmente cedido pela Dra. Andrea Balan. O objetivo era obter a enzima expressa na porção solúvel de maneira ativa. O clone pOP5MP/AaLip foi utilizado para transformar células competentes de E. coli BL21 (DE3) e a expressão foi induzida (Figura 29). O material proveniente da expressão da lipase L-Aa7055 foi submetido a um gel de SDS-PAGE. Não foi possível observar nenhuma banda com aparente indução, a banda da lipase teria o tamanho esperado de aproximadamente 37 kDa no gel. 


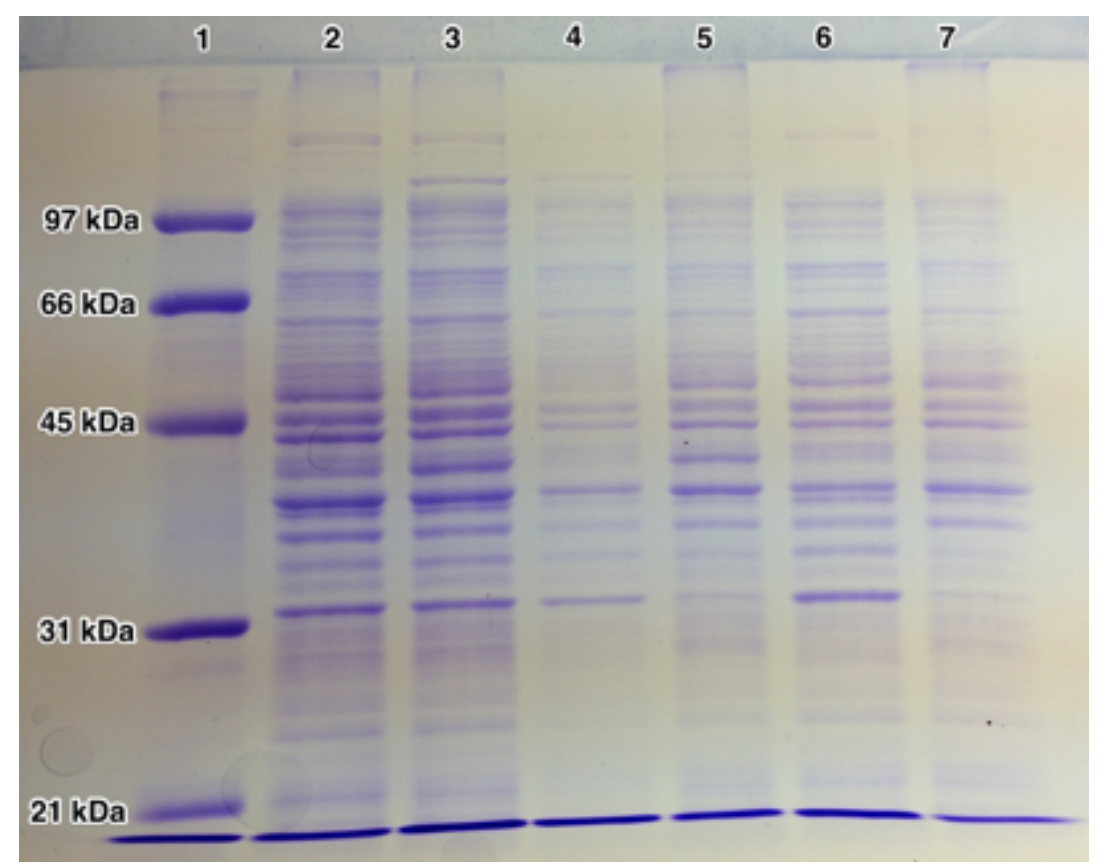

Figura 29 - SDS-PAGE 12\% corado com Coomassie do perfil de expressão proteica da lipase 7055 (E. coli BL21 (DE3) transformadas com o vetor pOP5MP). (1) Padrão de massa molecular, (2) fração não induzida após a lise, (3) fração induzida após a lise, (4) Fração induzida porção solúvel, (5) fração induzida porção insolúvel, (6) Fração não induzida porção solúvel e (7) fração não induzida porção insolúvel.

\subsubsection{Expressão das lipases L-Aa7055 e L-Aa7051 em vetor pET-SUMO}

O clone pET-SUMO/L7055 (Figura 30) foi utilizado para transformar E. coli (One shot Mach1-T1) e a expressão foi induzida na presença de IPTG $1 \mathrm{mM}$. O material proveniente da expressão piloto foi submetido a um gel de SDS-PAGE, onde foi possivel observar a expressão da lipase L-Aa7055 que apresentou uma banda de aproximadamente $47 \mathrm{kDa}$ (Figura 31). A expressão da lipase L-Aa7055 foi repetida em volumes maiores e o material foi submetido a cromatografia em coluna de níquel para purificação (Figura 32).

As frações provenientes da eluição realizada em coluna de níquel, foram analisadas através de experimento de atividade. Dada a impossibilidade do uso de substratos fluorescentes para medidas de atividade de lipase na presença de imidazol buscamos duas alternativas: o uso de DMPTB como substrato e a eluição por $\mathrm{pH}$ na ausência de imidazol. Em nenhuma das duas tentativas foi possível medir a atividade. 


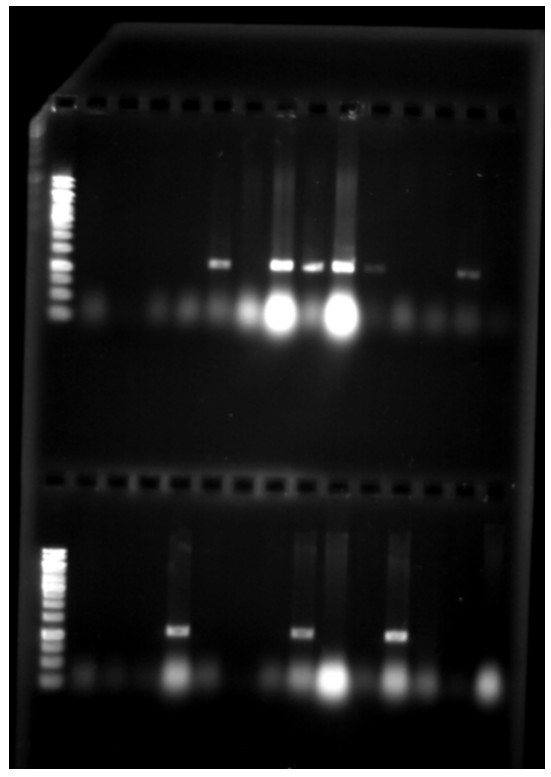

Figura 30 - Gel de agarose $1 \%$ corado com brometo de etídeo do produto de PCR de células clonadas com vetor pET-L7055, correspondentes ao inserto ( $\mathrm{L}$ Aa7055) a um trecho do vetor (pET-SUMO). As bandas $1056 \mathrm{pb}$ são correspondentes ao tamanho esperado para o inserto (L-Aa7055).

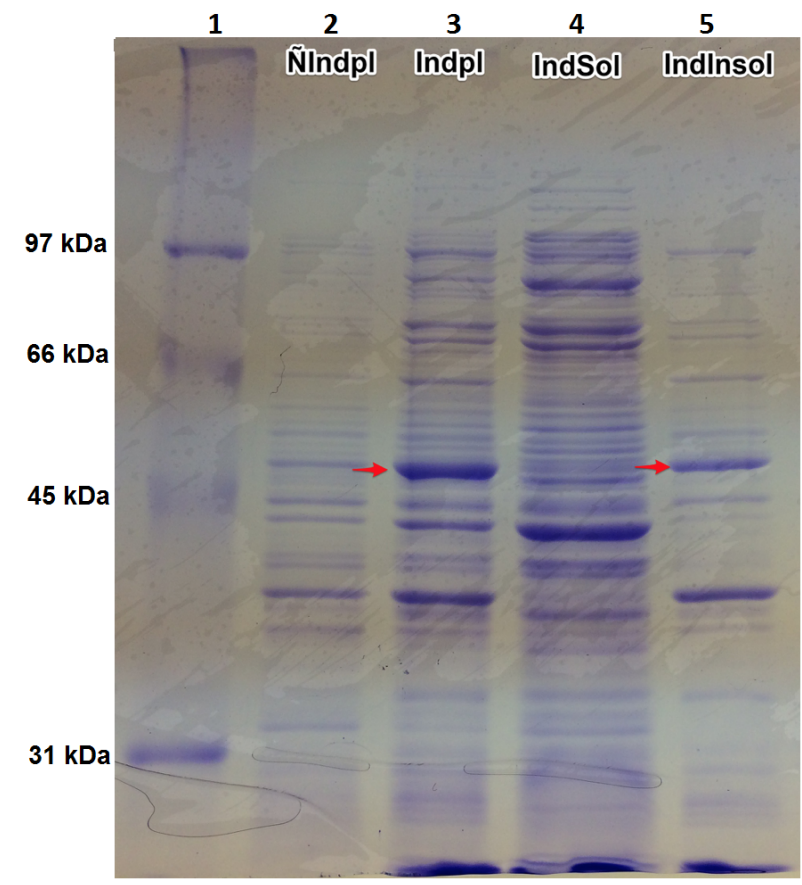

Figura 31 - Gel de SDS-PAGE 12\% corado com Coomassie do perfil de expressão proteica de L-Aa7055/Sum (E. colli BL21(DE3) transformadas com vetor pET-L7055), a lipase L-Aa7055 está indicada pela seta. (1) Padrão de massa molecular, (2 - Ñlndpl) não induzido após lise, (3 - Indpl) Indução com IPTG após lise, (4 - IndSol) Indução com IPTG porção solúvel e (5 Indlnsol) Indução com IPTG porção insolúvel. A banda de $47 \mathrm{kDa}$ é a fusão da lipase digestiva de Ae. aegypti $34 \mathrm{kDa}$ e da proteína de pET-SUMO 13 $\mathrm{kDa}$. 


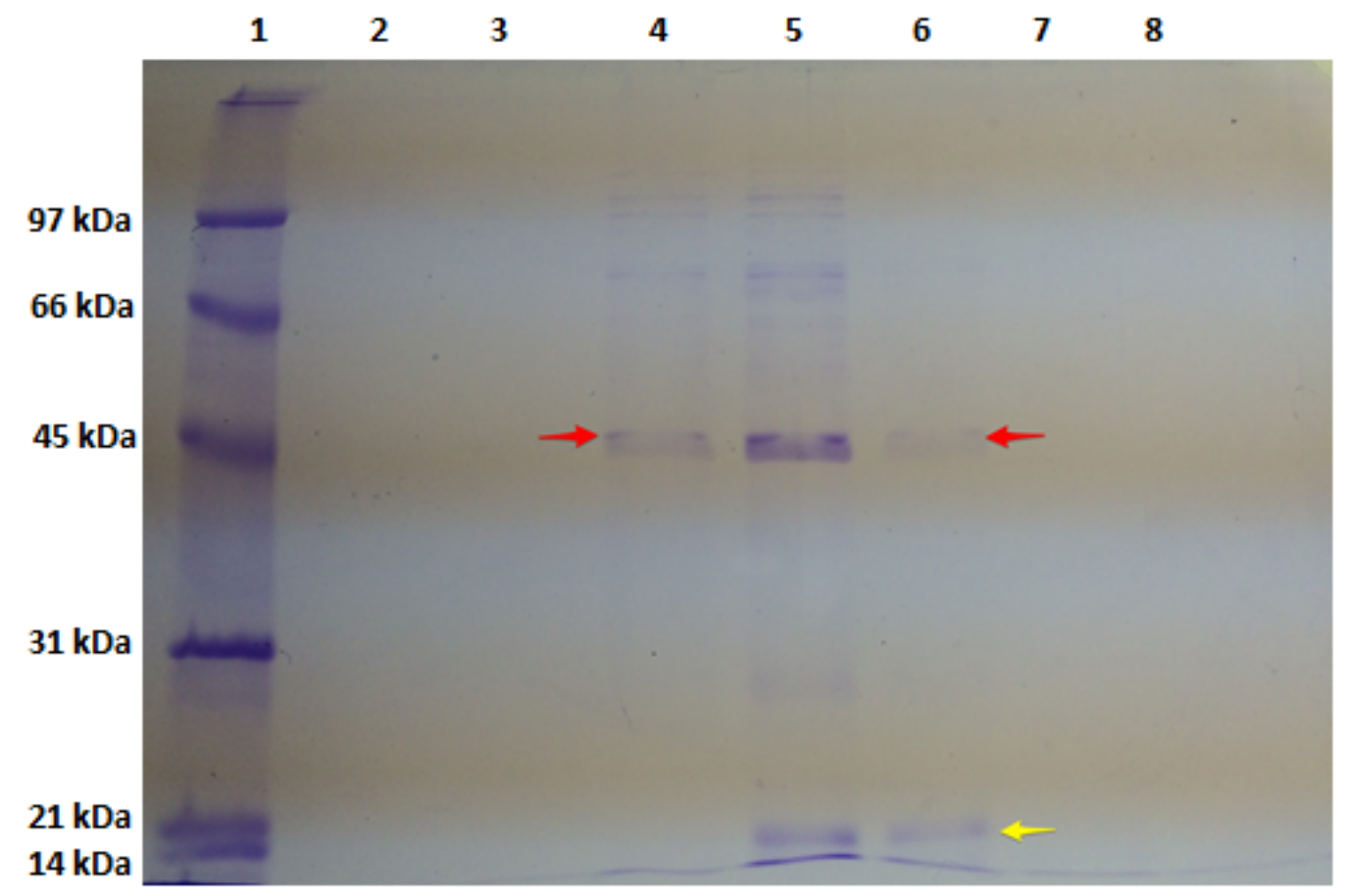

Figura 32 - Purificação da L-Aa7055 recombinante. Gel de SDS-PAGE 12\% corado com Coomassie do isolamento da lipase recombinante de Ae. aegypti L-Aa7055 em coluna de níquel (Ni-NTA). (1) padrão de massa molecular, (2, 3, 4, 5, 6, 7 e 8) frações eluídas com tampão de eluição. A banda de $47 \mathrm{kDa}$ é a fusão da lipase digestiva de Ae. aegypti 34 kDa e da proteína de pET-SUMO 13 kDa.

A identificação por LC-MS permitiu a confirmação da banda indicada pela seta vermelha como sendo a lipase L-Aa7055/Sum de Ae. aegypti (Figura 33), majoritariamente encontrada na porção insolúvel do material induzido. A atividade enzimática não pode ser medida na porção insolúvel, provavelmente indicando um dobramento inadequado da proteína. 


\begin{tabular}{|c|c|c|c|c|c|c|c|c|}
\hline \multicolumn{9}{|l|}{ Protein list: } \\
\hline $\begin{array}{c}\text { Protein } \\
\text { Group }\end{array}$ & $\begin{array}{c}\text { Protein } \\
\text { ID }\end{array}$ & Accession & $-10 \lg P$ & $\begin{array}{c}\text { Coverage } \\
(\%)\end{array}$ & \# Peptides & \#Unique & PTM & $\begin{array}{l}\text { Avg. } \\
\text { Mass }\end{array}$ \\
\hline 1 & 221 & $\begin{array}{l}\text { AAEL007055- } \\
\text { PA }\end{array}$ & 120.13 & 22 & 14 & 14 & $\mathrm{Y}$ & 37355 \\
\hline \multicolumn{6}{|c|}{ Description } & & & \\
\hline \multicolumn{6}{|c|}{ lipase|protein_coding|supercont1.233:488357-489441:1|gene:AAEL007055 } & & & \\
\hline
\end{tabular}

MVQFPVLLIT LSLAFEVHSS YAENRRLQLV RDIDGTQQLV NPNPYRVLNA HLERSFNAQS DIIFRLYTRK NPEKHQILKP

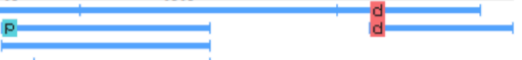

NDTSSILNSN FNADLPTRFL IHGWNQNGES DILIELRRSY LSVEDFNVIG VDWGEGALTI NYVMARKRVE SVGLVTSQLI

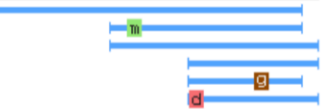

DTLVDASGVI LDSIYVIGHS LGAHVAGIVG KHQRGQLNTI VGLDPAGPLF SLNSSDILNQ NHAQYVEMVS TGARLLGTYE

281

241 PLGDANFYPN GGLEQAGCGL DLFGICAHAR SWIYFAETVT NGKGFRGIKC AMIEDLEGET CNLSGLPNVW MGGEPSNHER

321 GVKGIFMVHT NSEAPFAKD

Figura 33 - Identificação dos peptídeos obtidos pela digestão da lipase recombinante LAa7055 com quimotripsina em análise por espectrometria de massa (LCMS). A lipase recombinante L-Aa7055 com expressão induzida por IPTG teve sua banda correspondente recortada e tratada a partir de um gel de SDSPAGE (Fig. 3). O banco de dados de proteínas preditas geral do mosquito Ae. aegypti foi obtido no banco de dados VectorBase.

Foram obtidos clones da lipase L-Aa7051 utilizando o vetor pET-SUMO, os clones obtidos (pET-L7051) foram utilizados em diversas tentativas de transformação em E. coli (One shot Mach1-T1). A presença do plasmídeo (pETsumo mais L-Aa7051) foi testada em um número grande de colônias através de reação de PCR. Em nenhum desses testes foi observada a amplificação do gene de interesse. Devido a dificuldade de obtenção de colônias transformadas com pET-Aa7051 os experimentos de clonagem e expressão nesse sistema foram interrompidos.

\subsection{Determinação da atividade e efeito da concentração de Oleato sob a atividade da lipase L-Aa7055/Sum após a renaturação}

Após a renaturação da lipase L-Aa7055/Sum expressa majoritariamente na porção insolúvel, foi possível realizar medidas de atividade absoluta utilizando oleato e butirato como substratos. Os valores de atividade encontrados indicam a presença de uma enzima ativa, a atividade é proporcional a concentração de enzima 
comprovando que as variações de fluorescência observados são realmente devido a atividade enzimática.

A especificidade da lipase recombinante sobre o substrato oleato pode ser determinada. O valor de Km encontrado para a lipase L-Aa7055/Sum foi de $63 \mu \mathrm{M} \pm$ $6.0 \mu \mathrm{M}$. Os plotes de Lineweaver-Burk obtidos bem como as curvas de MichaelisMenten podem ser observadas na Figura 34.

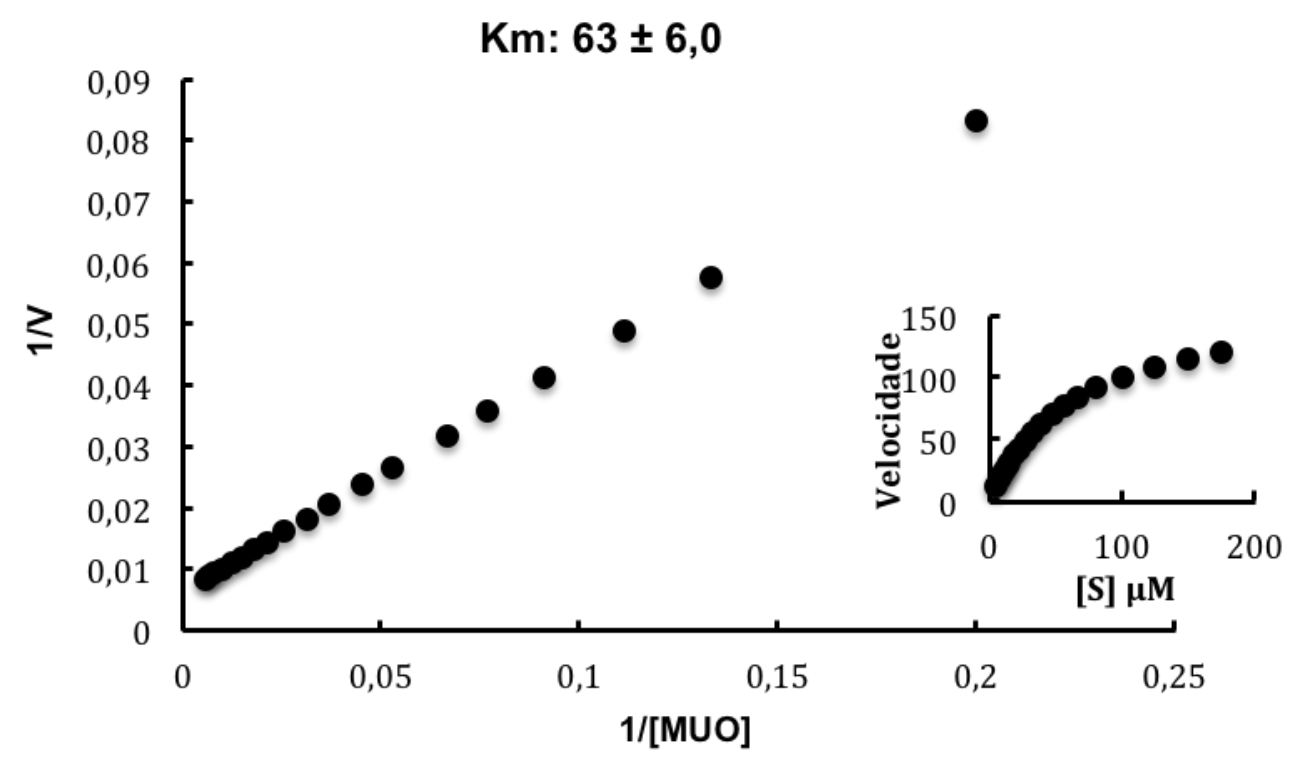

Figura 34 - Efeito da concentração do substrato MU-Oleato $(\mu \mathrm{M})$ sobre a atividade da lipase recombinante de Ae. aegypti L-Aa7055, após a renaturação. A figura representa o plote de Lineweaver-Burk a partir dos dados obtidos. O gráfico inserido é a curva de Michaelis-Menten. 


\section{DISCUSSÃO}

Os dados obtidos no estudo das lipases digestivas do mosquito Ae. aegypti, proporcionaram embasamento para discussões e comparações com dados descritos na literatura, como pode ser visto a seguir.

\subsection{Características estruturais das lipases L-Aa7051 e L-Aa7055}

Os genes AAEL007055 e AAEL007051 foram identificados por análise de sequências (Figura 8) e RT-PCR semi quantitativo (Figura 9) como enzimas digestivas do mosquito Ae. aegypti. Esses dados foram confirmados por qPCR, sendo a lipase L-Aa7055 expressa no intestino médio de fêmeas adultas (Figura 22) e a lipase L-Aa7051 no intestino médio larval (Figura 23). Essas sequências foram alinhadas com sequências de lipase descritas na literatura, permitindo a obtenção de uma árvore filogenética.

A árvore filogenética obtida não permite traçar a história evolutiva das lipases, pois existe uma saturação do sinal filogenético ao longo do tempo, o que é evidenciado pela presença abundante de genes parálogos que estão relacionados a ocorrência de duplicação gênica.

O alinhamento permitiu a comparação entre importantes regiões das sequências. Essas regiões estão relacionadas com a presença do domínio tampa, da alça $\beta 9$ e da região C-terminal, que são estruturas conhecidas por afetar a especificidade da lipase em relação ao substrato. As lipases de invertebrados encontradas nos subgrupos SG-P1, SG-P3 e em regiões intermediárias entre SG-P1 e SG-P2 apresentaram uma variação grande no tamanho geral de suas sequências, com variações no tamanho das estruturas (alças e do domínio tampa). As lipases digestivas descritas em insetos bem como as identificadas em Ae. aegypti se agruparam no subgrupo SG-P4. Esse grupo não apresentou a região C-terminal de ligação a colipase, o que é condizente com a ausência da coenzima em insetos. A colipase tem como principal função auxiliar na abertura do domínio tampa e sua estabilização o que expõe o sítio ativo com consequente aumento da hidrofobicidade (THOMAS et al., 2005; WONG; SCHOTZ, 2002).

As lipases digestivas dos aracnídeos, Nephilingis cruentata (aranha) e Tityus serrulatus (escorpião), tiveram suas sequências obtidas por sequenciamento de nova geração e confirmadas por proteoma FUZITA et al. $(2015,2016)$. A análise das 
sequências obtidas permitiu observar que elas apresentam a região C-terminal, que é o domínio onde ocorre a ligação a colipase. Conseguimos observar nesses estudos baseados em sequências que as lipases apresentam tamanhos distintos e podem estar envolvidas em diferentes funções. As lipases de invertebrados marinhos, por exemplo, foram analisadas recentemente e descritas como não possuidoras do domínio C-terminal de ligação a colipase (RIVERA-PEREZ, 2015). Estes autores analisaram lipases de 5 diferentes filos de invertebrados, dentre elas 46 lipases do crustáceo Daphnia pulex, sendo 21 delas neutras. Entretanto, em nossas análises observamos que uma das lipases de Daphnia pulex (E9H0C7) apresentou o domínio C-terminal, o mesmo tamanho na alça $\beta 9$ e domínio tampa que a LP. A sequência dessa enzima foi originalmente descrita no genoma de Daphnia pulex (COLBOURNE et al., 2011). Posteriormente, a mesma enzima foi descrita em um trabalho que mediu a expressão de genes na fase larval em diferentes condições de alimentação, alimentação rica e pobre em nutrientes, tendo sua expressão aumentada na alimentação pobre em nutrientes. O trabalho não localizou o tecido no qual essa lipase foi expressa, citando uma possível função digestiva ou na mobilização de reserva energética (DUDYCHA; BRANDON; DEITZ, 2011). No entanto, não existe nenhuma informação bioquímica na literatura para essa enzima.

Peptídeos tipo colipase já foram descritos no veneno da aranha Hadronyche versuta. Entretanto, a sua função não pode ser comprovada quando testada em ensaios com lipase de porco (SZETO et al., 2000). Análises realizadas no transcriptoma do intestino médio da aranha Nephilingis cruentata nos permitiram observar uma proteína que possui homologia parcial com a sequências de colipase, que é dada principalmente pela localização dos domínios de cisteína. Portanto, a presença de um cofator atuando na atividade de lipase desse animal não pode ser decartada sem testes prévios.

A alça $\beta 9$ das lipases digestivas de Ae. aegypti apresentam 15 resíduos de aminoácidos, uma redução de 6 resíduos quando comparada com a lipase pancreática humana. A redução do número de resíduos da alça $\beta 9$ já foi descrita na PRLP2 (proteína 2 relacionada a lipase pancreática) de porco da índia, o que acarreta em uma perda de hidrofobicidade local prejudicando a ligação da cadeia ácil de triacilgliceróis, levando a uma redução da taxa de hidrólise de substratos de cadeia longa (DIDRI et al., 2013). 
Aparentemente a diminuição do domínio tampa é uma característica presente nas lipases que atuam na digestão em insetos, reunidas no subgrupo SG-P4 em nossa análise (Figura 16). No mosquito Ae. aegypti a diminuição é grande, estando presentes na alça apenas 9 resíduos na fase larval e 6 resíduos na fase adulta. $O$ domínio tampa completo parece interagir com a interface lipídeo-água, o que leva a uma mudança conformacional que permite que os substratos insolúveis em água entrem em contato com o sítio ativo da enzima (CARRIERE et al.,1998; MILED et al., 2000).

A redução desse domínio foi estudada em PRLP2 de porco da índia, resultando em uma menor especificidade dessa enzima pelo substrato, permitindo sua atuação em substratos distintos de triacilgliceróis (AMARA et al., 2010; HJORTH et al., 1993; THIRSTRUP; VERGER; CARRIERE, 1994). Uma lipase intracelular descrita para o camarão Penaeus vannamei (Crustacea), que não apresenta o domínio C-terminal, possui a alça $\beta 9$ com 21 resíduos e o domínio tampa com 22 resíduos e se mostrou eficaz na hidrólise de TAGs de cadeia longa o que evidencia o papel do tamanho dessas estruturas em invertebrados (RIVERA-PEREZ; GARCIACARREÑO; SABOROWSKI, 2010; RIVERA-PEREZ; NAVARETE DEL TORO; GARCIA-CARREÑO, 2011).

Baseado nas características encontradas nas sequências das lipases digestivas do mosquito Ae. aegypti podemos presumir que essas enzimas tem uma ampla gama de atuação, não atuando somente sobre triacilgliceróis mas também sobre outros tipos de espécies lipídicas. Entretanto, apenas a constatação estrutural não permite afirmar a especificidade sobre determinado substrato. Estudos de "docking" realizados para as lipases humanas HL, LPL e EL, que apresentam especificidades distintas sobre triacilgliceróis e que apresentam o mesmo tamanho do domínio tampa, sugerem que a composição dos resíduos de aminoácidos seja mais importante para sua função que o tamanho da estrutura (WANG et al., 2013).

Considerando esse aspecto, observamos que existe uma diferença considerável entre as duas lipases digestivas de Ae. aegypti. As duas sequências de proteína foram alinhadas e apresentam apenas $45 \%$ de identidade, evidenciando a diferença na composição de aminoácidos o que pode alterar sua composição estrutural e funcionamento. A validação da análise estrutural precisa ser confirmada pela verificação da atividade dessas lipases sobre substratos específicos. 
A tentativa de medida da especificidade das lipases do mosquito sobre um TAG foi testado em ensaio titrimétrico conforme descrito na seção 3.2.3. Esse ensaio possui baixa sensibilidade. Os homogeneizados de intestino médio de $A e$. aegypti, fase larval e adulta, foram utilizados como fonte de enzimática permitindo observar aparente hidrólise de gliceril trioctanoato apenas pela lipase larval.

Os testes realizados com homogeneizado da fase adulta do mosquito não apresentaram nenhuma variação na inclinação. Os testes de atividade com substratos colorimétricos e fluorescentes realizados nas mesmas amostras mostraram atividade especifica geralmente 10 vezes maiores nos homogeneizados de larva, o que possivelmente explica a impossibilidade de observar variações no ensaio menos especifico (FILIETAZ., 2011). A obtenção dessas lipases de forma recombinante, em abundância, permitiria análises mais confiáveis.

A tentativa de identificação da lipase L-Aa7055 em frações cromatográficas ativas sobre oleato a partir de homogeneizado foi realizada por espectrometria de massa (em 3.11). Entretanto, não conseguimos identificar nenhuma sequência de lipase ou esterase no intestino do mosquito Ae. aegypti, o que indica a presença minoritária dessa proteína mesmo na fração enriquecida proveniente da cromatografia.

\subsection{Clonagem e expressão das lipases L-Aa7051 e L-Aa7055 em sistema recombinante}

Foram utilizados 3 sistemas de expressão para a obtenção das lipases na forma recombinante. Os clones obtidos no sistema $p A E$ não foram induzidos na presença de IPTG (em 4.5.1), no sistema pOP obtivemos clones para a lipase LAa7055 que também não foi induzida (em 4.5.2). A obtenção de um clone viável para L-Aa7055 foi obtido com a utilização do sistema pET-SUMO, tendo a sua expressão induzida E. coli BL21(DE3) conforme descrito na seção 4.5.3.

A expressão da lipase em sistema pET-SUMO foi majoritariamente encontrada na porção insolúvel e confirmada por espectrometria de massa, sendo essa enzima foi submetida a renaturação. Após o processo de renaturação foi possível obter valores de atividade, o que sugere que o redobramento tenha sido bem sucedido. A atividade medida com butirato foi maior que a observada com oleato, o mesmo efeito ocorre nas medidas em homogeneizado bruto do intestino dos mosquitos (FILIETAZ., 2011). Entretanto, o valor de $\mathrm{Km}$ para oleato encontrado 
em homogeneizados brutos do intestino médio de fêmeas adultas foi de $96 \mu \mathrm{M} \pm 14$ $\mu \mathrm{M}$, diferente do encontrado para a enzima recombinante $63 \mu \mathrm{M} \pm 6.0 \mu \mathrm{M}$. A diferença entre os valores encontrados não é suficientemente grande para se afirmar que não se trata da mesma enzima. Além disso, dois fatores podem estar relacionados a essa diferença: as medidas de $\mathrm{Km}$ em amostras de homogeneizados brutos podem sofrer interferência de outras moléculas presentes no homogeneizado de maneira a afetar sua ligação ao substrato ou a presença da proteína SUMO, adicionada à porção N-terminal da proteína expressa afetar a sua ligação ao substrato, favorecendo-a.

A lipase da mosca Musca domestica foi clonada e expressa com sucesso em sistema de expressão pAE (PADILHA, 2009). Essa enzima apresenta massa teórica de $36,8 \mathrm{kDa}$ bem próxima a encontrada para a lipase digestiva do mosquito $A e$. aegypti (34 kDa), pH ótimo de 7,5 sendo o $\mathrm{pH}$ ótimo da lipase presente no homogeneizado de intestino médio do mosquito de 8,5. A lipase de mosca apresenta maior atividade sobre substratos de cadeia curta o que também foi observado para a lipase encontrada no homogeneizado de intestino médio do mosquito tanto na fase larval como no adulto (FILIETAZ, 2011). Entretanto, não foi observada indução de nenhuma das lipases em estudo neste sistema.

\subsection{Lipases presentes nas fases de desenvolvimento do mosquito Ae. aegypti}

As lipases encontradas no genoma do mosquito Ae. aegypti fazem parte de uma família multigênica, com 72 sequências (NENE et al., 2007). Essas lipases, possivelmente, estão envolvidas nos mais distintos processos no mosquito, com possível relevância em mobilização de energia de reserva e na obtenção de energia através da alimentação (HORNE; HARITOS; OAKENSHOTT, 2009). Em serinopeptidases pelo menos 7 genes já foram descritos como expressos no sistema digestório, sendo alguns constitutivamente expressos e outros regulados pela alimentação (BRACKNEY; FOY; OLSON, 2008). Estes 7 genes de serino-peptidases previamente estudados foram utilizados para análise das 66 sequências de tripsinas, identificadas das 369 tripsinas no genoma do mosquito. As análises realizadas sugeriram que pode haver pelo menos mais 8 proteínas do tipo tripsina associadas com o intestino médio e induzidas pela alimentação sanguínea (VENANCIO et al., 2009). 
A presença de famílias multigênicas de lipases não é uma característica exclusiva do mosquito Ae. aegypti, podendo ser observada em outros insetos. Alguns trabalhos descrevem que a regulação da expressão gênica de lipases no sistema digestório de insetos pode ser mediada por efeitos externos, incluindo fatores como o tipo da alimentação e a presença de patógenos. Conseguimos observar que as lipases digestivas do mosquito Ae. aegypti apresentam regulação da expressão ligada a fase de desenvolvimento, sendo a amplificação do gene AAEL007051 encontrada na fase larval e do gene AAEL007055 na fase adulta. Possivelmente também está associada a diferentes dietas, dado que as larvas são detritívoras e as fêmeas adultas são hematófagas (Figuras 22 - 23).

O mosquito passa por mudanças fisiológicas significativas da fase larval para a adulta. Na fase larval a absorção e estocagem de nutrientes está ligada exclusivamente ao desenvolvimento do animal, podendo interferir até mesmo no potencial reprodutivo na fase adulta (RAY et al., 2009). Na fase adulta além da manutenção da vida, os nutrientes assumem uma segunda função, a de gerar energia para processos envolvidos com o desenvolvimento dos ovos. A importância da absorção na fase larval fica clara quando comparamos o nível de expressão da lipase digestiva de adultos L-Aa7055, 260 vezes (Figura 22B), com o nível de expressão lipase digestiva de larvas L-Aa7051, 42.000 vezes (Figura 23B), sendo a expressão da lipase L-Aa7051 160 vezes maior, o que possivelmente está ligado a necessidade de obtenção de lipídeos, sendo que a acumulação e mobilização desses nutrientes na fase larval são necessários para suporte na metamorfose e na constituição do corpo gorduroso da fase adulta (HORNE; HARITOS; OAKENSHOTT, 2009).

A dieta das larvas é bastante variada sendo constituída de material particulado, que pode incluir restos de plantas, algas, protistas, fungos e bactérias. A exposição a microorganismos na alimentação pode levar a infecção, que nesta fase do desenvolvimento pode prejudicar ou até mesmo inibir o desenvolvimento do animal. As enzimas digestivas do intestino médio podem atuar como uma barreira química contra microorganismos. A lipase digestiva de Bombyx mori tem a sua expressão estimulada na presença de um poliedrovirus, o que indica uma atividade anti-viral (PONNUVEL et al., 2003; XU et al., 2015). No mosquito Ae. aegypti uma beta-1,3-glucanase digestiva apresenta um papel de defesa por atuar na hidrólise de beta-1,3-glucana, principal polissacarídeo da parede celular de leveduras e fungos 
(SOUZA et al., 2016). Essa beta-1,3-glucanase não apresenta aumento nos níveis de atividade na alimentação com leveduras vivas. Talvez a lipase L-Aa7051 apresente o mesmo tipo de comportamento, tendo como função primária a digestão de lipídeos da dieta e apresentando uma função secundária de proteção devido a sua abundância e ação.

$\mathrm{Na}$ fase adulta, as fêmeas do mosquito dependem da alimentação sanguínea para o sucesso reprodutivo. A obtenção de lipídeos se dá pela digestão das lipoproteínas presentes no plasma sanguíneo.

O perfil de expressão obtido para a lipase L-Aa7055 mostrou que o nível de transcritos é constante, podendo ser observada no jejum, na alimentação com açúcar e após o repasto sanguíneo (Figura 24). No repasto sanguíneo, os dados obtidos em animais não infectados analisados por qPCR permitiram observar que em 12, 15 e 18 horas após a alimentação não foram encontradas variações significativas nos níveis de transcrito da lipase L-Aa7055 (Figura 25B). É conhecido para mosquitos que a expressão de enzimas digestivas pode ser antecipada, intermediária ou tardia (DANA et al., 2005). A lipase digestiva do mosquito pode ser considerada de atuação antecipada/intermediária, a sua atividade se estende desde o início da alimentação e vai aumentando até atingir seu pico de atividade em 15 horas com produção de mRNA constante. Este efeito provavelmente se deve a necessidade de obtenção rápida de nutrientes auxiliando as grandes transformações que ocorrem no corpo gorduroso do animal durante a vitelogênese, evitando a depleção das reservas energéticas (ATTARDO; HANSEN; RAIKHEL, 2005).

As peptidases de expressão antecipada (pico de atividade em 3 horas com declínio em 24 horas, ou antes), também apresentam níveis de transcrito prévio a alimentação. A regulação da transcrição dos genes das serino peptidases antecipadas é regulada pelo hormônio juvenil (BIAN et al., 2008; LI et al., 2014). O controle da tradução da tripsina de expressão antecipada (early trypsin) é regulada pela presença de aminoácidos em conjunto com a via TOR após a alimentação sanguínea (NORIEGA; COLONNA; WELLS, 1999; BRANDON et al., 2008). Com a tradução da tripsina de expressão antecipada, a digestão das proteínas presentes no sangue tem início, com consequente aumento de nutrientes.

O aumento dos níveis de aminoácidos na hemolinfa atua como sinalizador para o início da vitelogenêse, que depois é regulada pela presença do hormônio 20hidroequidizona (20-E). A ativação da vitelogênese faz com que o corpo gorduroso 
passe por modificações estruturais que facilitam a síntese proteica, sob controle do hormônio 20-E passando a produzir grandes quantidades da proteína "yolk" que são necessárias para a maturação dos ovos (ATTARDO; HANSEN; RAIKHEL, 2005).

A regulação da expressão de lipases digestivas de Drosophila melanogaster foi descrita e se mostrou relacionada a composição dos nutrientes ingeridos na dieta. No jejum prolongado foi observado um aumento da expressão enquanto houve uma redução da expressão na alimentação com açúcar (KUNTE et al., 2006; ZINKE et al., 2002).

O nível de expressão da L-Aa7055 de Ae. aegypti não foi regulado pela composição do alimento nas condições testadas, os níveis de expressão encontrados na alimentação com açúcar foram os mesmos da alimentação sanguínea (Figura 22B). Geralmente, a alimentação com açúcar não estimula a expressão da maioria dos genes no mosquito Anopheles, sendo normalmente estimulados pela alimentação sanguínea (DANA et al., 2005). Na literatura observamos que a lipase digestiva do mosquito apresenta um nível basal de atividade, que começa aumentar a partir de 10 horas atingindo um pico em 15 horas após o repasto sanguíneo, as medidas foram realizadas com uma emulsão de óleo de coco. Depois disso, os níveis decrescem até atingir níveis mínimos a partir de 48 horas. Esse mesmo trabalho demostrou que não foi possível observar atividade de lipase após a alimentação com açúcar, o que é bastante interessante pois observamos o mesmo nível de expressão de mRNA nesta alimentação (GEERING; FREYVOGEL, 1975).

Não podemos excluir a possibilidade de que essa lipase apresente regulação da transcrição do mRNA dependente de algum componente presente no sangue ou do aumento dos níveis de alguma substancia na hemolinfa após o início da digestão, apresentando um comportamento parecido com a tripsina de expressão antecipada de Ae. aegypti.

\subsection{Resposta da expressão da lipase L-Aa7055 na infecção por $P$. gallinaceum e DENV2}

A membrana peritrófica e as enzimas digestivas atuam como barreiras eficientes na infecção parasitária. O que fica evidente ao observarmos o baixo nível de sucesso ao transpor o intestino médio, os milhares de oocinetos iniciais resultam em aproximadamente meia dúzia de oocistos maduros. A invasão do epitélio do 
mosquito ocorre 24 horas após a ingestão do sangue infectado com $P$. gallinaceum, no exato período de maturação da membrana peritrófica que atinge o seu pico de espessura de 1 a $20 \mu \mathrm{m}$, o que dificulta a invasão (WANG; JACOBS-LORENA, 2013). O perfil de expressão das enzimas digestivas estudadas na fase adulta de Ae. aegypti é bastante parecido com o observado para An. gambiae, que é majoritariamente tardio entre 24 e 48 horas após o repasto e a difusão dessas enzimas no bolo alimentar considerada lenta. Portanto, os estágios iniciais do parasita acabam evitando o contato prolongado com a maior parte das enzimas digestivas, o que permite seu desenvolvimento adequado para a transposição da membrana (DANA et a., 2005; SARAIVA et al., 2016).

$\mathrm{Na}$ infecção viral o tempo de infecção é diferente do encontrado na infecção parasitária. O virion precisa estar em contato com as microvilosidades do intestino, pois dessa forma fica próximo ao revestimento das células epiteliais o que permite sua penetração. Esse processo tem que ocorrer antes da formação da membrana peritrófica que vai revestir o sangue ingerido (FRANZ et al., 2015). A membrana peritrófica fica evidente por volta de 4 a 6 horas após a alimentação, alcançando espessura e textura em 12 horas e com maturação completa em 24 horas (DEVENPORT; FUJIOKA; JACOBS-LORENA, 2004). O primeiro sinal de infecção pode ser visto 2 dias após a alimentação, onde poucas células epiteliais são infectadas podendo ser observadas em aproximadamente $30 \%$ do intestino (SALAZAR et al., 2007)

A atividade da lipase na fase intermediária no Ae. aegypti, com pico de atividade 15 horas, o que parece ser um característica interessante na ingestão de alimento contaminado. Talvez a presença dessa lipase dificulte a infecção, assim como a protease 5G1 de expressão tardia (Início em 6 a 8 horas e pico em 24 horas) que quando inibida leva a um aumento das taxas de infecção no mosquito (BRACKNEY; FOY; OLSON, 2008).

Sabendo que a presença de enzimas digestivas pode prejudicar a eficiência de infecção de $P$. gallinaceum e que a lipase é expressa de maneira intermediária, surgiu o interesse de estudar se a presença do patógeno poderia induzir a regulação da expressão gênica dessas lipases. A regulação da expressão de uma lipase digestiva é observada na infecção viral em larvas da lagarta Bombyx mori (XU et al., 2015). 
A regulação da expressão de algumas lipases de mosquitos foram descritas na literatura. No mosquito Ae. albopictus o processo de diapausa regula o metabolismo de lipídeos com a diminuição da expressão de diversos genes de lipases (REYNOLDS et al., 2012). Dezenove genes de lipase tiveram sua expressão aumentada em mosquitos Culex pipiens resistentes ao inseticida deltametrina, um piretróide que afeta o do transporte de sódio e potássio na membrana do axônio e também inibe a ATPase afetando a condução de cátions (LU et al., 2015). Esse processo está relacionado a resistência metabólica, onde ocorre alteração nos níveis de proteínas. Para que ocorra o aumento da síntese de proteínas detoxificantes o animal precisa aumentar o aporte energético e a mobilização dos nutrientes estocados (ARAÚJO et al., 2008).

Até o momento desse ensaio possuíamos duas informações sobre a expressão da lipase L-Aa-7055, lipase presente no animal adulto, a primeira observada por qPCR que a enzima era expressa no intestino de fêmeas adultas após a alimentação e a segunda informação que obtivemos por RT-PCR é que expressão dessa enzima é constante sendo encontrada amplificação em todos os tempos e condições testadas. Como o pico de atividade enzimática de lipase descrito se encontrava em 15 horas após a alimentação, acreditávamos que um intervalo de 3 horas entre os ponto de maior síntese proteica seria suficiente para observar alterações nos níveis de transcrito (GEERING; FREYVOGEL, 1975). Os testes de amplificação foram realizados 12, 15 e 18 horas após a alimentação.

Quando as fêmeas adultas do mosquito Ae. aegypti foram alimentadas com sangue infectado pelo parasita $P$. gallinaceum, observamos que a presença dos gametócitos no intestino médio do mosquito Ae. aegypti não é um estímulo para o aumento ou diminuição da transcrição da lipase digestiva L-Aa7055 nos tempos medidos (Figura 25A). Esse resultado indica que a lipase digestiva não apresenta uma associação direta com o sistema de defesa do animal.

Para determinar se a infecção afeta a expressão da lipase digestiva os mosquitos Ae. aegypti infectados por $P$. gallinaceum foram submetidos a um segundo repasto sanguíneo e os níveis de expressão da lipase L-Aa7055 foram novamente determinados. Não observamos modificação do nível de expressão da lipase em 12 e 15 horas após o repasto sanguíneo. No entanto existe uma redução de $30 \%$ na expressão dessa lipase após 18 horas (Figura 25B). 
Observamos que o perfil de expressão da lipase L-Aa7055 é distinto na infecção por DENV2 quando comparamos com a infecção por $P$. gallinaceum. Os animais também foram submetidos a um segundo repasto sanguíneo, mas não foi observada a redução da expressão dessa lipase em 18 horas como na infecção parasitária. Um trabalho realizado para verificar a fertilidade do mosquito $A e$. aegypti, mostrou que existe redução significativa do número de ovos e redução da viabilidade celular nas fêmeas alimentadas com sangue infectado por $P$. galinaceum (IOSHINO, 2013). O mesmo grupo realizou trabalhos preliminares mostrando que em animais infectados por DENV2 não foi observada redução no número de ovos no primeiro e segundo ciclo gonotrófico, sendo observada somente no terceiro ciclo gonotrófico. Esses dados somado aos dados obtidos demonstram que a infecção por $P$. gallinaceum reduz o "fitness" do animal, o que não é observado na infecção viral.

Apesar da redução observada em 18 horas na infecção parasitaria, a expressão da lipase L-Aa7055 parece constante nos pontos críticos da digestão. Possivelmente isso acontece para preservação das funções básicas, tendo em vista o aporte energético necessário para a vitelogênese. Foi descrito para larvas da lagarta Lymantria dispar que 24 horas após a infecção por Bacillus thuringiensis existe uma forte inibição dos genes envolvidos na digestão e aumento de genes relacionados a transcrição e ligação (SPARKS et al., 2013). A redução da transcrição em 18 horas após a infecção pode sinalizar o início da redução da expressão das enzimas digestivas do sistema.

Alguns tipos de análise poderiam ter sido realizados para compreender melhor a importância das lipases no processo infeccioso. Inicialmente, uma metodologia que poderia ser utilizada seria o sequenciamento de nova geração do sistema digestório no processo infeccioso para identificar outras lipases envolvidas na digestão bem como o efeito da infecção. A primeira seria acompanhar a expressão desse gene em tempos anteriores a 10 horas após a alimentação em animais previamente infectados; a segunda seria a realização de silenciamento gênico para verificar qual o efeito da ausência da lipase em animais infectados. 


\section{CONCLUSÃO}

Os dados cinéticos obtidos durante análises prévias indicavam a presença de duas atividades de lipases distintas nas duas fases de desenvolvimento, larval e de fêmeas adultas, do mosquito Ae. aegypti.

Através de análises de bioinformática conseguimos selecionar dentre as 72 sequências de lipase do genoma as possíveis candidatas a lipases digestivas. A confirmação dessa análise foi realizada por qPCR, onde conseguimos observar que as lipases do mosquito são expressas diferencialmente e isso está ligado a fase do desenvolvimento do animal. A lipase L-Aa7051 é expressa em grande quantidade no intestino médio de larvas enquanto a L-Aa7055 é expressa no intestino da fase adulta do mosquito.

Ao utilizarmos as sequências dessas lipases para realizar comparações estruturais, observamos que as lipases são distintas entre si, possuindo apenas $45 \%$ de identidade. Essas análises permitiram confirmar que essas enzimas fazem parte do grupo das lipases neutras o que vem de encontro com o observado previamente em ensaios cinéticos. As lipases não apresentam a região de ligação a colipase, que está presente no domínio C-terminal, região envolvida na abertura do domínio tampa. Observamos que as lipases do mosquito apresentam uma diminuição em outros domínios ligados a especificidade com o substrato, como a alça $\beta 9$ (perda de hidrofobicidade local com diminuição da ligação com substratos de cadeia longa) e o domínio tampa (menor especificidade ao substrato, podendo atuar na hidrólise de diferentes espécies lipídicas). Essas características apontam para diferenças de especificidade quando comparadas com as lipases neutras de humanos.

Foi possível obter a lipase L-Aa7055 na forma recombinante utilizando o sistema pET-SUMO. Entretanto, não foi possível obter essa enzima na porção solúvel tendo que ser submetida a renaturação. As tentativas de purificação utilizadas não foram bem sucedidas mesmo após a renaturação da proteína. Após o processo de renovelamento foi possível determinar atividade dessa enzima e determinar sua especificidade sobre o substrato oleato. $\mathrm{O}$ valor de $\mathrm{Km}$ encontrado é distinto do que foi observado para a enzima no homogeneizado bruto do mosquito. As principais hipóteses são: que estivéssemos medindo atividade de uma enzima distinta em homogeneizado; que a proteína acessória estaria interferindo no funcionamento da enzima recombinante; que os valores determinados em 
homogeneizados brutos podem ser imprecisos, devido a presença de moléculas que podem interferir na ligação da enzima ao substrato. $O$ fato de não termos conseguido identificar a lipase do mosquito presente na fração cromatográfica, utilizando espectrometria de massa em Orbitrap, demonstra a abundância das moléculas encontrada nesse material, pode evidenciar também: a presença minoritária dessa enzima no sistema digestório ou uma possível degradação da molécula (proteólise).

Observamos que o perfil de expressão da lipase L-Aa7055 possui características peculiares, sendo sua expressão constante o que foi observado pela presença de transcritos antes da alimentação, na alimentação com açúcar e com sangue. Não sabemos se os níveis de expressão são os mesmos em todos esses períodos, mas conseguimos verificar que essa enzima apresenta níveis de expressão constante em 12, 15 e 18 horas após a alimentação. Apesar da expressão parecer constante, existe um crescimento constante dos níveis de atividade com pico em 15 horas após a alimentação, talvez a lipase apresente o mesmo mecanismo de transcrição regulada hormonalmente e de tradução mediado pela presença de nutrientes. Esse tipo de regulação é observado para a tripsina de expressão antecipada. Observamos ainda que na infecção por $P$. gallinaceum os níveis de expressão permanecem constantes em 12 e 15, com redução em 18 horas. A expressão na infecção viral não apresentou alterações nos valores de expressão nos mesmos tempos medidos. A redução da expressão encontrada na infecção por $P$. gallinaceum pode acontecer pela necessidade do organismo do animal de reduzir a energia gasta na digestão para manutenção de proteínas relacionadas a imunidade. Ainda assim a expressão constante em 12 e 15 horas na infecção parasitária e em todos tempos medidos na infecção viral podem indicar que essa enzima é de grande importância nessa fase do desenvolvimento, pois processa os lipídeos da dieta fornecendo a energia que dá suporte as grandes transformações observadas na ovogênese e para a manutenção do sistema imune.

A digestão de lipídeos necessita ser melhor compreendida nesse animal, principalmente em relação a sua importância na fase adulta, tanto na fisiologia do animal quanto no processo infeccioso. Grande parte da reserva energética encontrada no corpo gorduroso do animal adulto é proveniente da obtenção de lipídeos na fase larval. Não se sabe ao certo quantas são as lipases atuantes no 
processo digestivo no adulto, quais seriam as suas especificidades e qual a relevância da ausência das mesmas no processo infeccioso. 


\section{REFERÊNCIAS*}

ADAMS, B.; KAPAN, D. D. Man bites mosquito: understanding the contribution of human movement to vector-borne disease dynamics. PLoS ONE, v. 4, p. e6763, 2009. Doi:10.1371/journal.pone.0006763

AGNANDJI, S. T.; LELL, B.; FERNANDES, J. F. F.; ABOSSOLO, B. P. P.; METHOGO, B. G.; KABWENDE, A. L.; ADEGNIKA, A. A.; MORDMÜLLER, B.; ISSIFOU, S.; KREMSNER, P. G.; SACARLAL, J.; AIDE, P.; LANASPA, M.; APONTE, J. J.; MACHEVO, S.; ACACIO, S.; BULO, H.; SIGAUQUE, B.; MACETE, E.; ALONSO, P.; ABDULLA, S.; SALIM, N.; MINJA, R.; MPINA, M.; AHMED, S.; ALI, A. M.; MTORO, A. T.; HAMAD, A. S.; MUTANI, P.; TANNER, M.; TINTO, H.; D'ALESSANDRO, U.; SORGHO, H.; VALEA, I.; BIHOUN, B.; GUIRAUD, I.; KABORÉ, B.; SOMBIÉ, O.; GUIGUEMDÉ, R. T.; OUÉDRAOGO, J. B.; HAMEL, M. J.; KARIUKI, S.; ONEKO, M.; ODERO, C.; OTIENO, K.; AWINO, N.; MCMORROW, M.; MUTURI-KIOI, V.; LASERSON, K. F.; SLUTSKER, L.; OTIENO, W.; OTIENO, L.; OTSYULA, N.; GONDI, S.; OTIENO, A.; OWIRA, V.; OGUK, E.; ODONGO, G.; WOODS, J. B.; OGUTU, B.; NJUGUNA, P.; CHILENGI, R.; AKOO, P.; KERUBO, C.; MAINGI, C.; LANG, T.; OLOTU, A.; BEJON, P.; MARSH, K.; MWAMBINGU, G.; OWUSU-AGYEI, S.; ASANTE, K. P.; OSEI-KWAKYE, K.; BOAHEN, O.; DOSOO, D.; ASANTE, I.; ADJEI, G.; KWARA, E.; CHANDRAMOHAN, D.; GREENWOOD, B.; LUSINGU, J.; GESASE, S.; MALABEJA, A.; ABDUL, O.; MAHENDE, C.; LIHELUKA, E.; MALLE, L.; LEMNGE, M.; THEANDER, T. G.; DRAKELEY, C.; ANSONG, D.; AGBENYEGA, T.; ADJEI, S.; BOATENG, H. O.; RETTIG, T.; BAWA, J.; SYLVERKEN, J.; SAMBIAN, D.; SARFO, A. A phase 3 trial of RTS,S/AS01 malaria vaccine in African infants. The New England Journal Of Medicine, v. 367, p. 228495, 2012.

ALIPOUR, E. Evaluation of effects of different experimental compounds on midgut lipase activity in galleria mellonella I. (lepidoptera: pyralidae). Munis Entomology \& Zoology, v. 8, p. 167-174, 2013.

AMARA, S.; BAROUH, N.; LECOMTE, J.; LAFONT, D.; ROBERT, S.; VILLENEUVE, P.; DE CARO, A.; CARRIERE F. Lipolysis of natural long chain and synthetic medium chain galactolipids by pancreatic lipase-related protein 2. Biochimica Et Biophysica Acta, v. 1801, n. 4, p. 508-516, 2010.

ANDRIKOPOULOS, N. K. Triglyceride species compositions of common edible vegetable oils and methods used for their identification and quantification. Food Reviews International, v.18, n.1, p. 71-102, 2002.

ANWAR, A.; SALEEMUDDIN, M. Alkaline-pH-acting digestive enzymes of the polyphagous insect pest Spilosoma obliqua: stabilityand potential as detergent additives. Biotechnology And Applied Biochemistry, v. 25, p. 43-46, 1997.

ARAÚJO, R. A.; GUEDES, R. N.; OLIVEIRA, M. G.; FERREIRA, G. H. Enhanced activity of carbohydrate- and lipid-metabolizing enzymes in insecticide-resistant populations of the maize weevil, Sitophilus zeamais. Bulletin Of Entomological Research, v. 98, p. 417-24, 2008.

* De acordo com: ASSOCIAÇÃO BRASILEIRA DE NORMAS TÉCNICAS. NBR 6023: informação e documentação: referências: elaboração. Rio de Janeiro, 2002. 
ARRESE, E. L.; CANAVOSO, L. E.; JOUNI, Z. E.; PENNINGTON, J. E.; TSUCHIDA, K.; WELLS, M. A. Lipid storage and mobilization in insects: current status and future directions. Insect Biochemistry And Molecular Biology, v. 31, p. 7-17, 2001.

ATTARDO, G.; HANSEN, I.; RAIKHEL, A. Nutritional regulation of vitellogenesis in mosquitoes: Implications for anautogeny, Insect Biochemistry And Molecular Biology, v. 35, p. 661-675, 2005.

BATON, L. A.; RANFORD-CARTWRIGHT, L. C. Morphological evidence for proliferative regeneration of the Anopheles stephensi midgut epithelium following Plasmodium falsiparum ookinete invasion. Journal Of Invertebrate Pathology, v. 96, p. 244-254, 2007.

BARRETT, A. D. Yellow Fever in Angola and Beyond--The Problem of Vaccine Supply and Demand. The New England Journal Of Medicine, v. 375, n. 4, 301303, 2016.

BERTOLACCI-ROCHA, L.; DA CUNHA, R.; DE LICHS, G.; FABBRO, M.; AND MOTTA-CASTRO, A. Introduction of the dengue virus type 4 in the State of Mato Grosso do Sul, Brazil. Cadernos De Saúde Pública, v. 30, 2014.

BHATT, S.; GETHING, P. W.; BRADY, O. J.; MESSINA, J. P.; FARLOW, A. W.; MOYES, C. L.; DRAKE, J. M.; BROWNSTEIN, J. S.; HOEN, A. G.; SANKOH, O.; MYERS, M. F.; GEORGE, D. B.; JAENISCH, T.; WINT, G. R.; SIMMONS, C. P.; SCOTT, T. W.; FARRAR, J. J.; HAY, S. I. The global distribution and burden of dengue. Nature, v. 496, p. 504-7, 2013.

BIAN, G.; RAIKHEL, A. S.; ZHU, J. Characterization of a juvenile hormone-regulated chymotrypsin-like serine protease gene in Aedes aegypti mosquito. Insect Biochemistry And Molecular Biology, v. 38, p.190-200, 2008.

BOLLADE, D.; PARIS, R.; MOULINS, M. Origine et mode d'action de la lipase intestinale chez les blattes. Journal Of Insect Physiology, v. 16, p. 45-53, 1970.

BRACKNEY, D. E.; FOY, B. D.; OLSON, K. E. Effects of midgut serine proteases on dengue virus type 2 infectivity of Aedes aegypti. The American Journal Of Tropical Medicine and Hygiene, v. 79, p. 267-274, 2008.

BRANDON, M. C.; PENNINGTON, J. E.; ISOE, J.; ZAMORA, J.; SCHILLINGER, A.S. S.; MIESFELD, R. L. TOR signaling is required for amino acid stimulation of early trypsin protein synthesis in the midgut of Aedes aegypti mosquitoes. Insect Biochemistry And Molecular Biology, v. 38, p. 916-22, 2008.

BRASIL. Ministério da Saúde. Secretaria de Vigilância em Saúde. Boletim Eletrônico Epidemiológico. Brasília: Ministério da Saúde, 2010. Disponível em: <www.saude.gov.br/svs> Acesso em: 07 maio 2011. 
BROCKERHOFF, H.; HOYLE, R. J.; HWANG, P. C. Digestive enzymes of the American Lobster (Homarus americanus). Journal Of The Fisheries Research Board Of Canada, v. 27, p. 1357-1370, 1970.

BRYANT, J. E.; HOLMES, E. C.; BARRETT, A. D. Out of Africa: a molecular perspective on the introduction of yellow fever virus into the Americas. PLoS Pathogens, v. 3, p. 0668-0673, 2007.

CAMPBELL, P.; CAO, A.; HINES, E.; EAST, P.; GORDON, K. Proteomic analysis of the peritrophic matrix from the gut of the caterpillar, Helicoverpa armigera. Insect Biochemistry And Molecular Biology, v. 38, p. 950-8, 2008.

CANAAN, S.; ROUSSEL, A.; VERGER, R.; CAMBILLAU, C. Gastric lipase: crystal structure and activity. Biochimica Et Biophysica Acta (BBA) - Molecular And Cell Biology Of Lipids, v. 1441, p. 197-204, 1999.

CANAVOSO, L. E.; FREDE, S.; RUBIOLO, E. R. Metabolic pathways for dietary lipids in the midgut of hematophagous Panstrongylus megistus (Hemiptera: Reduviidae). Insect Biochemistry And Molecular Biology, v. 34, p. 845-854, 2004.

CANAVOSO, L. E.; JOUNI, Z. E.; KARNAS, K. J.; PENNINGTON, J. E.; WELLS, M. A. Fat metabolism in insects. Annual Review Of Nutrition, v. 21, p. 23-46, 2001.

CANCINO-RODEZNO, A.; LOZANO, L.; OPPERT, C.; CASTRO, J. I.; LANZMENDOZA, H.; ENCARNACIÓN, S.; EVANS, A. E.; GILL, S. S., SOBERÓN, M.; JURAT-FUENTES, J. L.; AND BRAVO, A. Comparative proteomic analysis of Aedes aegypti larval midgut after intoxication with Cry11Aa toxin from Bacillus thuringiensis. PLoS ONE, v. 7, e37034, 2012.

CARRIERE, F.; BARROWMAN, J. A.; VERGER, R.; LAUGIER, R. Secretion and contribution to lipolysis of gastric and pancreatic lipases during a test meal in humans. Gastroenterology, v.105, p. 876-888, 1993.

CARRIERE, F.; WITHERS-MARTINEZ, C.; VAN TILBEURGH, H.; ROUSSEL, A.; CAMBILLAU, C.; VERGER, R. Structural basis for the substrate selectivity of pancreatic lipases and some related proteins. Biochimica Et Biophysica Acta, v. 1376, p. 417-432, 1998.

CENTER FOR DISEASE CONTROL AND PREVENTION. Mosquito Life Cycle. $2009 . \quad$ Disponível em: < http://www.cdc.gov/dengue/entomologyEcology/m_lifecycle.html > Acesso em: 28 jun. 2016.

CHEN, L. H.; WILSON, M. E. Dengue and chikungunya infections in travelers. Current Opinion In Infectious Diseases, v.23, p. 438-444, 2010.

CHERIF, S.; FENDRI, A.; MILED, N.; TRABELSI, H.; MEJDOUB, H.; GARGOURI, Y. Crab digestive lipase acting at high temperature: Purification and biochemical characterization. Biochimie, v. 89, p. 1012-1018, 2007. 
CHRISTELLER, J. T.; POULTON, J.; MARKWICK, N. M.; SIMPSON, R. M. The effect of diet on the expression of lipase genes in the midgut of the lightbrown apple moth (Epiphyas postvittana Walker; Tortricidae). Insect Molecular Biology, v. 19, p. 9-25, 2010.

CHRISTELLER, J.T.; AMARA, S.; CARRIÈRE, F. Galactolipase, phospholipase and triacylglycerol lipase activities in the midgut of six species of lepidopteran larvae feeding on different lipid diets. Journal Of Insect Physiology, v. 57, p. 1232-1239, 2011.

CIOTA, A.; KRAMER, L. Insights into Arbovirus Evolution and Adaptation from Experimental Studies, Viruses, v. 2, p. 2594-2617, 2010.

COIMBRA, T. M.; SANTOS, C. L.; SUZUKI, A.; PETRELLA, S.; BISORDI, I.; NAGAMORI, A. H.; MARTI, A. T.; SANTOS, R. N.; FIALHO, D. M.; LAVIGNE, S. Mayaro virus: imported cases of human infection in São Paulo state, Brazil. Revista Do Instituto De Medicina Tropical De São Paulo, v. 49, p. 221-224, 2007.

COLBOURNE, J.; PFRENDER, M.; GILBERT, D.; THOMAS, W.; TUCKER, A.; OAKLEY, T.; TOKISHITA, S.; AERTS, A.; ARNOLD, G.; BASU, M.; BAUER, D.; CÁCERES, C.; CARMEL, L.; CASOLA, C.; CHOI, J.-H.; DETTER, J.; DONG, Q.; DUSHEYKO, S.; EADS, B.; FRÖHLICH, T.; GEILER-SAMEROTTE, K.; GERLACH, D.; HATCHER, P.; JOGDEO, S.; KRIJGSVELD, J.; KRIVENTSEVA, E.; KÜLTZ, D.; LAFORSCH, C.; LINDQUIST, E.; LOPEZ, J.; MANAK, J.; MULLER, J.; PANGILINAN, J.; PATWARDHAN, R.; PITLUCK, S.; PRITHAM, E.; RECHTSTEINER, A.; RHO, M.; ROGOZIN, I.; SAKARYA, O.; SALAMOV, A.; SCHAACK, S.; SHAPIRO, H.; SHIGA, Y.; SKALITZKY, C.; SMITH, Z.; SOUVOROV, A.; SUNG, W.; TANG, Z.; TSUCHIYA, D.; TU, H.; VOS, H.; WANG, M.; WOLF, Y.; YAMAGATA, H.; YAMADA, T.; YE, Y.; SHAW, J.; ANDREWS, J.; CREASE, T.; TANG, H.; LUCAS, S.; ROBERTSON, H.; BORK, P.; KOONIN, E.; ZDOBNOV, E.; GRIGORIEV, I.; LYNCH, M.; BOORE, J. The ecoresponsive genome of Daphnia pulex. Science, v. 331, p. 555-61, 2011.

CONSOLI, R. A. G. B.; LOURENÇO-DE-OLIVEIRA, R. Principais Mosquitos de Importância Sanitária no Brasil. 2th ed. Fiocruz, Rio de Janeiro, 1998. 228 pp.

COSTA-DA-SILVA, A. L. L.; NAVARRETE, F. R. R.; SALVADOR, F. S.; KARINACOSTA, M.; IOSHINO, R. S.; AZEVEDO, D. S.; ROCHA, D. R. R.; ROMANO, C. M.; CAPURRO, M. L. Glytube: a conical tube and parafilm M-based method as a simplified device to artificially blood-feed the dengue vector mosquito, Aedes aegypti. PLoS ONE, v. 8, e53816, 2013.

CUGOLA, F. R.; FERNANDES, I. R.; RUSSO, F. B.; FREITAS, B. C.; DIAS, J. L. L.; GUIMARÃES, K. P.; BENAZZATO, C.; ALMEIDA, N.; PIGNATARI, G. C.; ROMERO, S.; POLONIO, C. M.; CUNHA, I.; FREITAS, C. L.; BRANDÃO, W. N.; ROSSATO, C.; ANDRADE, D. G.; FARIA, D. DE P.; GARCEZ, A. T.; BUCHPIGEL, C. A.; BRACONI, C. T.; MENDES, E.; SALL, A. A.; ZANOTTO, P. M.; PERON, J. P.; MUOTRI, A. R.; BELTRÃO-BRAGA, P. C. The Brazilian Zika virus strain causes birth defects in experimental models. Nature, v. 534, p. 267-71, 2016. 
DA CUNHA SAIS, T.; DE MORAES, R. M.; RIBOLLA, P. E.; DE BIANCHI, A. G.; MARINOTTI, O.; BIJOVSKY. A. T. Morphological aspects of salivary glands. Arthropod Structure \& Development, v. 32, p. 219-226, 2003.

DANA, A. N.; HONG, Y. S.; KERN, M. K. Gene expression patterns associated with blood-feeding in the malaria mosquito Anopheles gambiae. BMC Genomics, v. 6, n. 5, 2005.

DANA, A. N.; HONG, Y. S.; KERN, M. K.; HILLENMEYER, M. K.; HARKER, B. W.; LOBO, N. F.; HOGAN, J. R.; ROMANS, P.; COLLINS, F. H. (2005) Gene expression patterns associated with blood-feeding in the malaria mosquito Anopheles gambiae. BMC Genomics, v. 6, n. 5, 2005.

DAVID, J.-P.; FAUCON, F.; CHANDOR-PROUST, A.; POUPARDIN, R.; RIAZ, M., BONIN, A.; NAVRATIL, V.; REYNAUD, S. Comparative analysis of response to selection with three insecticides in the dengue mosquito Aedes aegypti using mRNA sequencing. Bmc Genomics, v. 15, n. 174, 2014.

DAVIDSON, A.; SLAVINSKI, S.; KOMOTO, K.; RAKEMAN, J.; WEISS, D. Suspected Female-to-Male Sexual Transmission of Zika Virus - New York City, 2016. Morbidity And Mortality Weekly Report. ePub: 15 July 2016. DOI: http://dx.doi.org/10.15585/mmwr.mm6528e2

DE ARAGAO, M.; VAN DER LINDEN, V.; BRAINER-LIMA, A.; COELI, R.; ROCHA, M.; DA SILVA, P.; DE CARVALHO, M.; VAN DER LINDEN, A.; DE HOLANDA, A.; AND VALENCA, M. Clinical features and neuroimaging (CT and MRI) findings in presumed Zika virus related congenital infection and microcephaly: retrospective case series study. BMJ, v. 353, 2016.

DE FIGUEROA, J. M.; TRENZADO, C. E.; LÓPEZ-RODRÍGUEZ, M. J.; SANZ, A. Digestive enzyme activity of two stonefly species (Insecta, Plecoptera) and their feeding habits. Comparative Biochemistry And Physiology. Part A, Molecular \& Integrative physiology, v. 160, p. 426-30, 2011.

DELÉCLUSE A.; PÉREZ V. J.; BERRY C. Vector-active toxins: structure and diversity. In: CHARLES, J. F.; DELE'CLUSE, A.; LEROUX, C. N. (Eds.). Entomopathogenic bacteria: From laboratory to field application. Dordrecht: Kluwer, 2000. p. 101-126.

DEREWENDA, Z. S. Structure and function of lipases. Advances In Protein Chemistry, v. 45, p. 1-52, 1994.

DEVENPORT, M.; FUJIOKA, H.; JACOBS-LORENA, M. Storage and secretion of the peritrophic matrix protein Ag-Aper1 and trypsin in the midgut of Anopheles gambiae. Insect Molecular Biology, v. 13, n. 4, p. 349-358, 2004.

DRIDI, K.; AMARA, S.; BEZZINE, S.; RODRIGUEZ, J.; CARRIÈRE, F.; GAUSSIER, $\mathrm{H}$. Partial deletion of $\beta 9$ loop in pancreatic lipase-related protein 2 reduces enzyme activity with a larger effect on long acyl chain substrates. Biochimica Et Biophysica Acta Bba - Molecular Cell Biology of Lipids, v. 1831, p. 1293-1301, 2013. 
DUDYCHA, J.; BRANDON, C.; DEITZ, K. Population genomics of resource exploitation: insights from gene expression profiles of two Daphnia ecotypes fed alternate resources. Ecology and Evolution, v. 2, p. 329-40, 2012.

DURBIN, A. P. A Dengue Vaccine. Cell, v. 166, n. 1, 2016.

FARIA, N. R.; AZEVEDO, R. DO S.; KRAEMER, M. U.; SOUZA, R.; CUNHA, M. S.; HILL, S. C.; THÉZÉ, J.; BONSALL, M. B.; BOWDEN, T. A.; RISSANEN, I.; ROCCO, I. M.; NOGUEIRA, J. S.; MAEDA, A. Y.; VASAMI, F. G.; MACEDO, F. L. DE L.; SUZUKI, A.; RODRIGUES, S. G.; CRUZ, A. C.; NUNES, B. T.; MEDEIROS, D. B.; RODRIGUES, D. S.; NUNES QUEIROZ, A. L.; DA SILVA, E. V.; HENRIQUES, D. F.; TRAVASSOS DA ROSA, E. S.; DE OLIVEIRA, C. S.; MARTINS, L. C.; VASCONCELOS, H. B.; CASSEB, L. M.; SIMITH, D. DE B.; MESSINA, J. P.; ABADE, L.; LOURENÇO, J.; CARLOS JUNIOR ALCANTARA, L.; DE LIMA, M. M. M.; GIOVANETTI, M.; HAY, S. I.; DE OLIVEIRA, R. S.; LEMOS, P. DA S.; DE OLIVEIRA, L. F.; DE LIMA, C. P.; DA SILVA, S. P.; DE VASCONCELOS, J. M.; FRANCO, L.; CARDOSO, J. F.; VIANEZ-JÚNIOR, J. L. L.; MIR, D.; BELLO, G.; DELATORRE, E.; KHAN, K.; CREATORE, M.; COELHO, G. E.; DE OLIVEIRA, W. K.; TESH, R.; PYBUS, O. G.; NUNES, M. R.; VASCONCELOS, P. F. Zika virus in the Americas: Early epidemiological and genetic findings. Science, v. 352 , p. $345-9$, 2016.

FAYE, O.; FREIRE, C. C.; IAMARINO, A.; FAYE, O.; DE OLIVEIRA, J. V.; DIALLO, M.; ZANOTTO, P. M.; SALL, A. A. Molecular evolution of Zika virus during its emergence in the 20(th) century. PLoS Negleted Tropical Disease, v.8, n. 1, e2636, 2014.

FIELDS, W.; KIELIAN, M. Interactions involved in $\mathrm{pH}$ protection of the alphavirus fusion protein. Virology, v. 486, p. 173-9, 2015.

FIGUEIREDO, L. T. Serious disease outbreaks caused by viruses transmitted by Aedes aegypti in Brazil. Revista Da Sociedade Brasileira de Medicina Tropical, v. 49, p. 265-6, 2016.

FIGUEIREDO, M. L.; FIGUEIREDO, L. T. Emerging alphaviruses in the Americas: Chikungunya and Mayaro. Revista Da Sociedade Brasileira De Medicina Tropical, v.47, p. 677-83, 2014.

FILIETAZ, C. F. T. Caracterização da digestão de lipídeos em vetores hematófagos e o papel fisiológico das lipases. 2011. 99 f. Dissertação (Mestrado em Parasitologia) - Instituto de Ciências Biomédicas, Universidade de São Paulo, São Paulo, 2011.

FILIETAZ, C. F. T.; LOPES, A. R. Caracterização de lipases em Arthropoda. Revista De Pesquisa E Inovação Farmacêutica, v. 2, p. 23-36, 2010.

FORATTINI, O. P. Aedes (Stegomyia). In: Culicidologia médica. São Paulo: Edusp, 2002. v. 2. p. 462-463. 
FUZITA, F. J.; PINKSE, M. W.; PATANE, J. S. S.; JULIANO, M. A.; VERHAERT, P. D.; LOPES, A. R. Biochemical, transcriptomic and proteomic analyses of digestion in the scorpion Tityus serrulatus: insights into function and evolution of digestion in an ancient arthropod. PLoS ONE, v. 10, e0123841, 2015.

FRANZ, A.; KANTOR, A.; PASSARELLI, A.; CLEM, R. Tissue Barriers to Arbovirus Infection in Mosquitoes, Viruses, v. 7, p. 3741-3767, 2015.

GARSKE, T.; KERKHOVE, M.; YACTAYO, S.; RONVEAUX, O.; LEWIS, R.; STAPLES, J.; PEREA, W.; FERGUSON, N.; COMMITTEE, Y. Yellow Fever in Africa: estimating the burden of disease and impact of mass vaccination from outbreak and serological data. Plos Medicine, v. 11, e1001638, 2014.

GEERING, K.; FREYVOGEL, T. A. Lipase activity and stimulation mechanism of esterase en midgut of female Aedes aegypti. Journal of Insect Physiology, v. 21, p. 1251-1256, 1975.

GHOSH, A.; JACOBS-LORENA, M. (2011) Surface-expressed enolases of Plasmodium and other pathogens. Memórias Instituto Oswaldo Cruz, v. 106, p. 85-90, 2011.

GOULD, E. A.; SOLOMON, T. Pathogenic flaviviruses. Lancet, v. 371, p. 500-509, 2008.

GRANDADAM, M.; CARO, V.; PLUMET, S.; THIBERGE, J.-M.; SOUARÈS, Y.; FAILLOUX, A.-B.; TOLOU, H. J.; BUDELOT, M.; COSSERAT, D.; LEPARCGOFFART, I. Chikungunya virus, southeastern France. Emerging Infectious Diseases, v. 17, p. 910-914, 2011.

GRILLO, L. A. M.; MAJEROWICZ, D.; GONDIM, K. C. Lipid metabolism in Rhodnius prolixus (Hemiptera: Reduviidae): Role of a midgut triacylglycerol-lipase. Insect Biochemistry And Molecular Biology, v. 37, p. 579-588, 2007

GROSSMAN, G. L.; CAMPOS, Y.; SEVERSON, D. W. Evidence for two distinct members of the amylase gene family in the yellow fever mosquito, Aedes aegypti, Insect Biochemistry And Molecular Biology, v. 27, n. 8/9, p. 769-781, 1997.

GU, J.; LIU, M.; DENG, Y.; PENG, H.; CHEN, X. Development of an efficient recombinant mosquito densovirus-mediated RNA interference system and its preliminary application in mosquito control. PLoS ONE, v. 6, p. e21329, 2011. doi: 10.1371/journal.pone.0021329.

GUBLER, D. J. Dengue and dengue hemorrhagic fever. Clinical Microbiology Reviews, v. 11, p. 480-96, 1998.

GUBLER, D. J. Epidemic dengue/dengue hemorrhagic fever as a public health, social and economic problem in the $21^{\text {st }}$ century. TRENDS In Microbiology, v.10, p. 100103, 2002. 
GUSMÃO, D. S.; SANTOS, A. V.; MARINI, D. C.; RUSSO, E. S.; PEIXOTO, A. M. D.; JÚNIOR, M. B.; BERBET-MOLINA, M. A.; LEMOS, F. J. A. First isolation of microorganisms from the gut diverticulum of Aedes aegypti (Diptera: Culidae): new perspectives for insect-bacteria association. Memórias Do Instituto Oswaldo Cruz, v. 102, p. 919-924, 2007.

HALSTEAD, S. B. Licensed Dengue Vaccine: Public Health Conundrum and Scientific Challenge. The American Journal Of Tropical Medicine And Hygiene, $v$. 95, n. 4. p. 741-745, 2016.

HARKER, B. W.; BEHURA, S. K.; DEBRUYN, B. S.; LOVIN, D. D.; MORI, A.; ROMERO-SEVERSON, J.; SEVERSON, D. W. Stage-specific transcription during development of Aedes aegypti. BMC Developmental Biology, v. 13, n. 29, 2013.

HARRINGTON, L. C.; EDMAN, J. D.; SCOTT, T. W. Why do female Aedes aegypti (Diptera: Culicidae) feed preferentially and frequently on human blood? Jounal Of Medical Entomology, v. 38, p. 411-422, 2001.

HENNESSEY, M.; FISCHER, M.; STAPLES, J. E. Zika Virus Spreads to New Areas - Region of the Americas, May 2015-January 2016. Morbidity And Mortality Weekly Report, v. 65, n. 3, p. 55-58, 2016. DOI: http://dx.doi.org/10.15585/mmwr.mm6503e1.

HERDE, M.; HOWE, G. Host plant-specific remodeling of midgut physiology in the generalist insect herbivore Trichoplusia ni. Insect Biochemistry And Molecular Biology. v. 50, p. 58-67, 2014.

HJORTH, A.; CARRIĖRE, F.; CUDREY, C.; WÖLDIKE, H.; BOEL, E.; LAWSON, D. M.; FERRATO, F.; CAMBILLAU, C.; DODSON, G. G.; THIM, L. A structural domain (the lid) found in pancreatic lipases is absent in the guinea pig (phospho)lipase. Biochemistry, v. 32, p. 4702-4707, 1993.

HOFFMAN, A. G. D.; DOWNER, R. G. H. End product specificity of triacylglycerol lipases from intestine, fat body, muscle and hemolymph of the American cockroach, Periplaneta americana L. Lipids, v. 14, p. 893-899, 1979.

HOLMES, R. S.; COX, L. A.; VANDEBERG, J. L. Comparative studies of mammalian acid lipases: Evidence for a new gene family in mouse and rat (Lipo). Comparative Biochemistry and Physiology, Part D. v. 5, p. 217-26, 2010.

HOLMQUIST, M. Alpha/Beta-Hydrolase Fold Enzymes: Structures, Functions and Mechanisms. Current Protein \& Peptide Science, v. 1, p. 209-235, 2000.

HONÓRIO, N.; CÂMARA, D.; CALVET, G.; BRASIL, P. Chikungunya: uma arbovirose em estabelecimento e expansão no Brasil. Cadernos De Saúde Pública, v. 31, p. 906-908, 2015.

HORNE, I.; HARITOS, V. S.; OAKESHOTT, J. G. Comparative and functional genomics of lipases in holometabolous insects. Insect Biochemistry Molecular Biology, v. 39, p. 547-567, 2009. 
INSTITUTO OSWALDO CRUZ. Dengue - Vírus e Vetor. Disponível em: < http://www.ioc.fiocruz.br/dengue/textos/oportunista.html> . Acesso em: 06 ago. 2016.

IOSHINO, R. S. Mecanismos da regulação de fertilidade de Aedes aegypti infectado por Plasmodium gallinaceum. 2013. 65 f. Dissertação (Mestrado em Parasitologia)_ - Instituto de Ciências Biomédicas, Universidade de São Paulo, São Paulo, 2011.

ISOE, J.; RASCÓN JR, A. A.; KUNZ, S.; MIESFELD, R. L. Molecular genetic analysis of midgut serine proteases in Aedes aegypti mosquitoes. Insect Biochemistry And Molecular Biology, v. 39, p. 903-912, 2009.

JIANG, L.; WANG, G. H.; CHENG, T. C.; YANG, Q.; JIN, S. K.; LU, G.; WU, F. Q.; XIAO, Y.; XU, H. F.; XIA, Q. Y. Resistance to Bombyx mori nucleopolyhedrovirus via overexpression of an endogenous antiviral gene in transgenic silkworms. Archives Of Virology, v. 157, p. 1323-1328, 2012.

JURCZYSZYN, A.; CZEPIEL, J.; GDULA-ARGASIŃSKA, J.; PAŚKO, P.; CZAPKIEWICZ, A.; LIBROWSKI, T.; PERUCKI, W.; BUTRYM, A.; CASTILLO, J. J.; SKOTNICKI, A. B. Plasma fatty acid profile in multiple myeloma patients. Leukemia Research, 2015.

KATO, N.; MUELLER, C.; FUCHS, J.; MCELROY, K.; WESSELY, V.; HIGGS, S.; CHRISTENSEN, B. Evaluation of the function of a type I peritrophic matrix as a physical barrier for midgut epithelium invasion by mosquito-borne pathogens in Aedes aegypti. Vector Borne And Zoonotic Diseases, v. 8, p. 701-12, 2008.

KIM, W.; BAE, S.; PARK, K.; LEE, S.; CHOI, Y.; HAN, S.; KOH, Y. Biochemical characterization of digestive enzymes in the black soldier fly, Hermetia illucens (Diptera: Stratiomyidae). Journal Of Asia-Pacific Entomology, v. 14, p. 11-14, 2011.

KUNTE, A. S.; MATTHEWS, K. A.; RAWSON, R. B. Fatty acid auxotrophy in Drosophila larvae lacking SREBP. Cell Metabolism. v. 3, p. 439-48, 2006.

LI, Y.; ZENG, X.-N. Effects of periplocoside $X$ on midgut cells and digestive enzymes activity of the soldiers of red imported fire ant. Ecotoxicology And Environmental Safety, v. 93, p. 1-6, 2013.

LI, M.; LIU, P.; WILEY, J. D.; OJANI, R.; BEVAN, D. R.; LI, J. A steroid receptor coactivator acts as the DNA-binding partner of the methoprene-tolerant protein in regulating juvenile hormone response genes. Molecular And Cellular Endocrinology, v. 394, p. 47-58, 2014.

LINSER, P. J.; SMITH, K. E.; SERON, T. J.; NEIRA OVIEDO, M. Carbonic anhydrases and anion transport in mosquito midgut $\mathrm{pH}$ regulation. The Journal of Experimental Biology, v. 212, p. 1662-71, 2009. 
LONG, M.; THORNTON, K. Gene Duplication and Evolution, Science, v. 293, p. 1551, 2001.

LÓPEZ-RODRÍGUEZ, M. J.; TRENZADO, C. E.; TIERNO DE FIGUEROA, J. M.; SANZ, A. Digestive enzyme activity and trophic behavior in two predator aquatic insects (Plecoptera, Perlidae): a comparative study. Comparative Biochemistry And Physiology. Part A, Molecular \& Integrative Physiology, v. 162, p. 31-5, 2012.

LOWE, M. E. The triglyceride lipases of the pancreas. Journal Of Lipid Research, v. 43, p. 2007-2016, 2002.

LV, Y.; WANG, W.; HONG, S.; LEI, Z.; FANG, F.; GUO, Q.; HU, S.; TIAN, M.; LIU, B.; ZHANG, D.; SUN, Y.; MA, L.; SHEN, B.; ZHOU, D.; ZHU, C. Comparative transcriptome analyses of deltamethrin-susceptible and -resistant Culex pipiens pallens by RNA-seq. Molecular Genetics And Genomics, v. 291, p. 309-321, 2015.

LYNCH, M.; CONERY, J. S. The evolutionary fate and consequences of duplicate genes. Science, v. 290, p. 1151-5, 2000.

MAGALHÃES, T. What is the association of heme aggregates with the peritrophic matrix of adult female mosquitoes?. Parasites And Vectors, v. 7, p. 362, 2014.

MALE, K. B.; STOREY, K. B. Triglyceride, diglyceride and monoglyceride lipases in Periplaneta Americana, Locusta migratoria and Polia adjunct. Insect Biochemistry, v. 11, p. 423-427, 1981.

MARKWICK, N. P.; POULTON, J.; MCGHIE, T. K.; WOHLERS, M. W.; CHRISTELLER, J. T. The effects of the broad-specificity lipase inhibitor, tetrahydrolipstatin, on the growth, development and survival of the larvae of Epiphyas postvittana (Walker) (Tortricidae, Lepidoptera). Journal Of Insect Physiology, v. 57, p. 1643-50, 2011.

MARZINEK, J. K.; HOLDBROOK, D. A.; HUBER, R. G.; VERMA, C.; BOND, P. J. Pushing the Envelope: Dengue Viral Membrane Coaxed into Shape by Molecular Simulations. Structure, v. 24, p. 1410-20, 2016.

MCGRAW, E. A.; O'NEILL, S. L. (2013) Beyond insecticides: new thinking on an ancient problem. Nature Review Microbiology, v. 11, p. 181-93, 2013.

MILED, N.; CANAAN, S.; DUPUIS, L.; ROUSSEL, A.; RIVIĖRE, M.; CARRIÈRE, F.; CARO, A.; CAMBILLAU, C.; VERGER, R. Digestive lipases: From three-dimensional structure to physiology. Biochimie, v. 82, p. 973-986, 2000.

MINISTÉRIO DA SAÚDE. Aspectos epidemiológicos da febre amarela silvestre e a vigilância intensificada durante período de monitoramento, Brasil, 2012/2013. Boletim Epidemiológico. Brasília, 2014. V45, $n^{07}$. Disponível em: <www.saude.gov.br/svs> Acesso em: 07 jun. 2014. 
MINISTÉRIO DA SAÚDE. Febre de Chikungunya: manejo clínico. Departamento De Vigilância Das Doenças Transmissíveis. Brasília, 2015. Disponível em: http://bvsms.saude.gov.br/bvs/publicacoes/febre_chikungunya_manejo_clinico.pdf Acesso em: 15 jun. 2016

MONATH, T. Yellow fever vaccine. Expert Review Of Vaccines, v. 4, p. 553-574, 2005.

MOREIRA-FERRO, C. K.; MARINOTTI, O.; BIJOVSKY, A. T. Morphological and biochemical analyses of the salivary glands of the malaria vector, Anopheles darlingi. Tissue And Cell, v. 33, n. 3, p. 264-273, 1999.

MOREIRA, L. A.; ITURBE-ORMAETXE, I.; JEFFERY, J. A.; LU, G.; PYKE, A. T.; HEDGES, L. M.; ROCHA, B. C.; HALL-MENDELIN, S.; DAY, A.; RIEGLER, M.; HUGO, L. E.; JOHNSON, K. N.; KAY, B. H.; MCGRAW, E. A.; van den HURK, A. F.; RYAN, P. A.; O'NEILL, S. L. A Wolbachia symbiont in Aedes aegypti limits infection with dengue, chikungunya, and Plasmodium. Cell, v. 139, p. 1268-1278, 2009.

MRDAKOVIC, M.; LAZAREVIC, J.; PERIC-MATARUGA, V.; IJIN, L.; VLAHOVIC, M. Partial characterization of a lipase from gypsy moth (Lymantria dispar L.) larval midgut. Folia Biologica (Krakow), v. 56, p. 103-110, 2008.

MU, H.; PORSGAARD, T. The metabolism of structured triacylglycerols. Progress In Lipid Research, v. 44, p. 430-448, 2005.

MUKHOPADHYAY, S.; KUHN, R.J.; ROSSMANN, M. G. A structural perspective of the flavivirus life cycle. Nature Reviews, v. 3, p. 13-22, 2005.

MUKHERJEE, D.; MISHRA, P.; JOSHI, M.; THAKUR, P. K.; HOSUR, R. V.; JARORI, G. K. EWGWS insert in Plasmodium falciparum ookinete surface enolase is involved in binding of PWWP containing peptides: Implications to mosquito midgut invasion by the parasite. Insect Biochemistry And Molecular Biology, v. 68, p. 13-22, 2016.

MUSSO, D.; GUBLER, D. J. Zika Virus. Clinical Microbiology Reviews, v. 29, p. 487-524, 2016.

MUSSO, D.; ROCHE, C.; ROBIN, E.; NHAN, T.; TEISSIER, A.; CAO-LORMEAU, V.M. M. (2015) Potential sexual transmission of Zika virus. Emerging Infectious Diseases, v. 21, p. 359-61, 2015.

NACIONAL CENTER FOR BIOTECHNOLOGY INFORMATION. BLASTp. Disponível em: < https://blast.ncbi.nlm.nih.gov/Blast.cgi?PAGE=Proteins>. Acesso em: 06 out. $2016 a$.

NACIONAL CENTER FOR BIOTECHNOLOGY INFORMATION. BLAST. Disponível em: http://www.ncbi.nlm.nhi.gov. Acesso em: 06 jun. 2016b.

NENE, V.; WORTMAN, J. R.; LAWSON, D.; HAAS, B.; KODIRA, C.; TU, Z.; LOFTUS, B.; XI, Z.; MEGY, K.; GRABHERR, M.; REN, Q.; ZDOBNOV, E. M.; LOBO, N. F.; CAMPBELL, K. S.; BROWN, S. E.; BONALDO, M. F.; ZHU, J.; SINKINS, S. P.; 
HOGENKAMP, D. G.; AMEDEO, A.; ARENSBURGER, P.; ATKINSON, P. W.; BIDWELL, S.; BIEDLER, J.; BIRNEY, E.; BRUGGNER, R. V.; COSTAS, J.; COY, M. R.; CRABTREE, J.; CRAWFORD, M.; DEBRUYN, B.; DECAPRIO, D.; EIGLMEIER, K.; EISENSTADT, E.; EL-DORRY, H.; GELBART, W. M.; GOMES, S. L.; HAMMOND, M.; HANNICK, L. I.; HOGAN, J. R.; HOLMES, M. H.; JAFFE, D.; JOHNSTON, J. S.; KENNEDY, R. C.; KOO, H.; KRAVITZ, S.; KRIVENTSEVA, E. V.; KULP, D.; LABUTTI, K.; LEE, E.; LI, S.; LOVIN, D. D.; MAO, C.; MAUCELI, E.; MENCK, C. F. M.; MILLER, J. R.; MONTGOMERY, P.; MORI, A.; NASCIMENTO, A. L.; NAVEIRA, H. F.; NUSBAUM, C.; O'LEARY, S.; ORVIS, J.; PERTEA, M.; QUESNEVILLE, H.; REIDENBACH, K. R.; ROGERS, Y.; ROTH, C. W.; SCHNEIDER, J. R.; SCHATZ, M.; SHUMWAY, M.; STANKE, M.; STINSON, E. O.; TUBIO, J. M. C.; VANZEE, J. P.; VERJOVSKI-ALMEIDA, S.; WERNER, D.; WHITE, O.; WYDER, S.; ZENG, Q.; ZHAO, Q.; ZHAO, Y.; HILL, C. A.; RAIKHEL, A. S.; SOARES, M. B.; KNUDSON, D. L.; LEE, N. H.; GALAGAN, I. J.; SALZBERG, S. L.; PAULSEN, I. T.; DIMOPOULOS, G.; COLLINS, F. H.; BIRREN, B.; FRASERLIGGETT, C. M.; SEVERSON, D. W. Genome sequence of Aedes aegypti a major arbovirus vector, Science, v. 316, p. 1718-1722, 2007.

NIAID (National Institute of Allergy and Infectious Diseases). VectorBase. Disponível em: < https://www.vectorbase.org>. Acesso em: 06 out. 2016.

NORIEGA, F. G., COLONNA, A. E., AND WELLS, M. A. Increase in the size of the amino acid pool is sufficient to activate translation of early trypsin mRNA in Aedes aegypti midgut. Insect Biochemistry And Molecular Biology, v. 29, p. 243-7, 1999.

NUNES, M. R.; FARIA, N. R.; DE VASCONCELOS, J. M.; GOLDING, N.; KRAEMER, M. U.; DE OLIVEIRA, L. F.; AZEVEDO, R. DO S.; DA SILVA, D. E.; DA SILVA, E. V.; DA SILVA, S. P.; CARVALHO, V. L. L.; COELHO, G. E.; CRUZ, A. C.; RODRIGUES, S. G.; VIANEZ, J. L.; NUNES, B. T.; CARDOSO, J. F.; TESH, R. B.; HAY, S. I.; PYBUS, O. G.; VASCONCELOS, P. F. Emergence and potential for spread of Chikungunya virus in Brazil. BMC Medicine, v. 13 (102), 2015.

PADILHA, M. H. P. Fisiologia molecular digestiva de Musca domestica (Diptera). 2009. $121 \mathrm{f}$. Tese (Doutorado em Bioquímica) - Instituto de Química, Universidade de São Paulo, São Paulo. 2009.

PASVOL, G. Protective hemoglobinopathies and Plasmodium falciparum transmission. Nature Genetics, v. 42, n. 4, p. 284-5, 2010.

PINONI, S. A.; IRIBARNE, O.; LÓPEZ MAÑANES, A. A. Between-habitat comparison of digestive enzymes activities and energy reserves in the SW Atlantic euryhaline burrowing crab Neohelice granulata. Comparative Biochemistry And Physiology Part A, v. 158, p. 552-559, 2011.

PONNUVEL, K. M.; NAKAZAWA, H.; FURUKAWA, S.; ASAOKA, A.; ISHIBASHI, J.; TANAKA, H.; YAMAKAWA, M. A lipase isolated from the silkworm Bombyx mori shows antiviral activity against nucleopolyhedrovirus. Journal Of Virology, v. 77, p. 10725-10729, 2003. 
RASGON, J. L.; STYER, L. M.; SCOTT, T. W. Wolbachia-induced mortality as a mechanism to modulate pathogen transmission by vector arthropods. Journal Of Medical Entomology, v. 40, p. 125-132, 2008.

RAY, K.; MERCEDES, M.; CHAN, D.; CHOI, C. Y.; NISHIURA, J. T. Growth and differentiation of the larval mosquito midgut. Journal Of Insect Science, v. 9, p. 113, 2009.

RESH, V. H.; CARDÉ, R. T. Encyclopedia Of insects. 2nd ed. Burlington: Academic Press, 2009.

REYNOLDS, J. A.; POELCHAU, M. F.; RAHMAN, Z.; ARMBRUSTER, P. A.; DENLINGER, D. L. Transcript profiling reveals mechanisms for lipid conservation during diapause in the mosquito, Aedes albopictus. Jounal of Insect Physiology, v. 58, p. 966-73, 2012.

REZZA, G.; NICOLETTI, L.; ANGELINI, R.; ROMI, R.; FINARELLI, A. C. Infection with chikungunya virus in Italy: an outbreak in a temperate region. The Lancet, $v$. 370, p. 1840-1846, 2007.

RIVERA-PEREZ, C. Marine invertebrate lipases: Comparative and functional genomic analysis. Comparative Biochemistry and Physiology, Part D, v. 15, p. 39-48, 2015.

RIVERA-PÉREZ, C.; GARCÍA-CARREÑO, F.; SABOROWSKI, R. Purification and Biochemical Characterization of Digestive Lipase in Whiteleg Shrimp. Marine Biotechnology, v. 13, p. 284-295, 2010.

RIVERA-PÉREZ, C.; NAVARRETE DEL TORO, M. A.; GARCÍA-CARREÑO, F. Purification and characterization of an intracellular lipase from pleopods of whiteleg shrimp (Litopenaeus vannamei). Comparative Biochemistry And Physiology, Part B, v. 158, p. 99-105, 2011.

RODRIGUEZ-BARRAQUER, I.; CORDEIRO, M. T.; BRAGA, C.; DE SOUZA, W. V.; MARQUES, E. T.; CUMMINGS, D. A. From re-emergence to hyperendemicity: the natural history of the dengue epidemic in Brazil. PLoS Negleted Tropical Disease, v. 5, n. 1, e935, 2011.

ROTHMAN, A. Immunity to dengue virus: a tale of original antigenic sin and tropical cytokine storms. Nature Reviews Immunology, v. 11, p. 532-543, 2011.

ROUSSEL, A.; CANAAN, S.; EGLOFF, M. P.; RIVIĖRE, M.; DUPUIS, L.; VERGER, R.; CAMBILLAU, C. Crystal structure of human gastric lipase and model of lysosomal acid lipase, two lipolytic enzymes of medical interest. The Journal Of Biological Chemistry, v. 274, p. 16995-7002, 1999.

SABCHAREON, A.; WALLACE, D.; SIRIVICHAYAKUL, C.; LIMKITTIKUL, K.; CHANTHAVANICH, P.; SUVANNADABBA, S.; JIWARIYAVEJ, V.; DULYACHAI, W.; PENGSAA, K.; WARTEL, T. A.; MOUREAU, A.; SAVILLE, M.; BOUCKENOOGHE, A.; VIVIANI, S.; TORNIEPORTH, N. G.; LANG, J. Protective efficacy of the 
recombinant, live-attenuated, CYD tetravalent dengue vaccine in Thai schoolchildren: a randomised, controlled phase 2b trial. Lancet, v. 380, p. 1559-67, 2012.

SALAZAR, M.I.; RICHARDSON, J.H.; SÁNCHEZ-VARGAS, I.; OLSON, K.E.; BEATY, B.J. Dengue virus type 2: replication and tropisms in orally infected Aedes aegypti mosquitoes, BMC Microbiol, v. 7, n. 9, 2007.

SANCHIS, V.; BOURGUET, D. Bacillus thuringiensis: applications in agriculture and insect resistance management. A review. Agronomy For Sustainable

Development, v. 28, n. 1, p. 11-20, 2008.

SARAIVA, R. G. G.; KANG, S.; SIMÕES, M. L.; ANGLERÓ-RODRÍGUEZ, Y. I.; DIMOPOULOS, G. Mosquito gut antiparasitic and antiviral immunity. Developmental And Comparative Immunology, v. 64 p. 53-64, 2016.

SCHNEIDER, B. S.; HIGGS, S. The enhancement of arbovirus transmission and disease by mosquito saliva is associated with modulation of the host immune response. Transactions Of The Royal Society Of Tropical Medicine And Hygiene, v. 102, p. 400-408, 2008.

SELCK, F. W.; ADALJA, A. A.; BODDIE, C. R. An estimate of the global health care and lost productivity costs of dengue. Vector borne And zoonotic diseases, v. 14, p. 824-6, 2014.

SHEPARD, D. S.; UNDURRAGA, E. A.; HALASA, Y. A.; STANAWAY, J. D. (2016) The global economic burden of dengue: a systematic analysis. Lancet Infectious Disease, v. 16, n. 8, p. 935-941, 2016.

SILVA, V. C.; PINHEIRO, N. L.; SCHERER, P. O.; FALCÃO, S. S., RIBEIRO, V. R.; MENDES, R. M. M.; CHAVES, R.; CHAGAS, R., CARDOZO-DE-ALMEIDA, M.; DOS SANTOS-MALLET, J. R. Histology and ultrastructure of Aedes albopictus larval midgut infected with Bacillus thuringiensis var. israelensis. Microscopy research And technique, v. 71, p. 663-668, 2008.

SMITH, G. M.; ROTHWELL, K.; WOOD, S. L.; YEAMAN, S. J.; BOWNES, M. Specificity and localization of lipolytic activity in adult Drosophila melanogaster. Biochemical Journal, v. 304, p. 775-779, 1994.

SOUZA, R. S.; DIAZ-ALBITER, H. M.; DILLON, V. M.; DILLON, R. J.; GENTA, F. A. Digestion of Yeasts and Beta-1,3-Glucanases in Mosquito Larvae: Physiological and Biochemical Considerations. PLoS ONE, v. 11, n. 3, e0151403, 2016.

SPARKS, M. E.; BLACKBURN, M. B.; KUHAR, D.; GUNDERSEN-RINDAL, D. E. Transcriptome of the Lymantria dispar (gypsy moth) larval midgut in response to infection by Bacillus thuringiensis. PLoS ONE, v. 8, 2013. e61190.

STEINERT, S.; LEVASHINA, E. A. Intracellular immune dipteran insects. Immunological Reviews, v. 240, p. 129-140, 2011. 
STYER, L. M.; LIM, P.-Y.; LOUIE, K. L.; ALBRIGHT, R. G.; KRAMER, L. D.; BERNARD, K. A. Mosquito Saliva Causes Enhancement of West Nile Virus Infection in Mice. Journal Of Virology, v. 85, p. 1517-1527, 2011.

SUTHANGKORNKUL, R., SIRICHAIYAKUL, P., SUNGVORNYOTHIN, S., THEPOUYPORN, A., SVASTI, J., AND ARTHAN, D. Functional expression and molecular characterization of Culex quinquefasciatus salivary a-glucosidase (Mall). Protein Expression And Purification, v. 110, p. 145-50, 2015.

SZETO, T. H.; WANG, X. H.; SMITH, R.; CONNOR, M.; CHRISTIE, M. J.; NICHOLSON, G. M.; KING, G. F. Isolation of a funnel-web spider polypeptide with homology to mamba intestinal toxin 1 and the embryonic head inducer Dickkopf-1. Toxicon, v. 38, p. 429-42, 2000.

SWISS INSTITUTE OF BIOINFORMATICS. ExPASy. Disponível em: < http://www.expasy.org>. Acesso em: 06 Out. 2016.

TEMPORÃO, J. G.; PENNA, G. O.; CARMO, E. H.; COELHO, G. E. Dengue virus serotype 4, Roraima state, Brazil. Emerging Infectious Deseases, v. 17, n. 5, p. 938-939, 2011.

TERRA, W. R.; FERREIRA, C. Biochemistry of digestion. Comprehensive molecular insect science, Comprehensive Molecular Insect Science, v.4, p.171-224, 2005.

TERRA, W. R.; FERREIRA, C. Insect digestive enzymes: properties, compartmentalization and function. Comparative Biochemistry And Physiology, v. 109B, p. 1-62, 1994.

TERRA, W. R.; FERREIRA, C. Biochemistry and Molecular Biology of Digestion. In: GILBERT, L. I. Insect Molecular Biology And Biochemistry. 1th ed. London: Academic Press, 2012. pp. 365-418.

THIRSTRUP, K.; VERGER, R.; CARRIERE, F. Evidence for a pancreatic lipase subfamily with new kinetic properties. Biochemistry, v. 33, n. 10, p. 2748-56, 1994.

THOMAS, A.; ALLOUCHE, M.; BASYN, F.; BRASSEUR, R.; KERFELEC, B. Role of the Lid Hydrophobicity Pattern in Pancreatic Lipase Activity. Journal Of Biological Chemistry, v. 280, p. 40074-40083, 2005.

TOPRAK, U.; BALDWIN, D.; ERLANDSON, M.; GILLOTT, C.; HOU, X.; COUTU, C.; HEGEDUS, D. D. A chitin deacetylase and putative insect intestinal lipases are components of the Mamestra configurata (Lepidoptera: Noctuidae) peritrophic matrix. Insect Molecular Biology, v. 17, p. 573-85, 2008.

TSETSARKIN, K.; VANLANDINGHAM, D.; MCGEE, C.; HIGGS, S. A Single Mutation in Chikungunya Virus Affects Vector Specificity and Epidemic Potential. Plos Pathogens, v. 3, n.12, e201, p. 1895-1906, 2007.

TSUSHIDA, K.; WELLS, M. A. Digestion, absorption, transport and storage of fat during the last larval stadium of Manduca sexta. Changes in the role of lipophorin in 
the delivery of dietary lipids to the fat body. Insect Biochemistry, v. 18, p. 263-268, 1988.

UNIPROT. Swiss-Prot. Disponível em: < http://www.uniprot.org>. Acesso em: 06 Out. 2016.

URDANETA-MARQUEZ, L.; FAILLOUX, A.-B. B. Population genetic structure of Aedes aegypti, the principal vector of dengue viruses. Infection, Genetics and Evolution, v. 11, p. 253-61, 2011.

VAZEILLE, M.; GABORIT, P.; MOUSSON, L.; GIROD, R.; FAILLOUX, A.-B. B. Competitive advantage of a dengue 4 virus when co-infecting the mosquito Aedes aegypti with a dengue 1 virus. BMC Infectious Disease, v. 16, n. 318, 2016.

VEGA-RODRÍGUEZ, J.; GHOSH, AK. Multiple pathways for Plasmodium ookinete invasion of the mosquito midgut. PNAS, v. 111, n. 4, p. E492-E500, 2014.

VEGA-RÚA, A.; LOURENÇO-DE-OLIVEIRA, R.; MOUSSON, L.; VAZEILLE, M.; FUCHS, S.; YÉBAKIMA, A.; GUSTAVE, J.; GIROD, R.; DUSFOUR, I.; LEPARCGOFFART, I.; VANLANDINGHAM, D. L.; HUANG, Y.-J. S. J.; LOUNIBOS, L. P.; MOHAMED ALI, S.; NOUGAIREDE, A.; DE LAMBALLERIE, X.; FAILLOUX, A.-B. B. Chikungunya virus transmission potential by local Aedes mosquitoes in the Americas and Europe. PLoS Neglected Tropical Diseases, v. 9, e0003780, 2015.

VENANCIO, T. M.; CRISTOFOLETTI, P. T.; FERREIRA, C.; VERJOVSKI-ALMEIDA, S.; TERRA, W. R. The Aedes aegypti larval transcriptome: a comparative perspective with emphasis on trypsins and the domain structure of peritrophins. Insect Molecular Biology, v. 18, p. 33-44, 2009.

VICENTE, C. R.; HERBINGER, K.-H. H.; FRÖSCHL, G.; MALTA ROMANO, C.; DE SOUZA AREIAS CABIDELLE, A.; CERUTTI JUNIOR, C. Serotype influences on dengue severity: a cross-sectional study on 485 confirmed dengue cases in Vitória, Brazil. BMC Infectious Diseases, v. 16, n. 320, 2016.

VILLAR, L.; DAYAN, G. H.; ARREDONDO-GARCÍA, J. L. L.; RIVERA, D. M.; CUNHA, R.; DESEDA, C.; REYNALES, H.; COSTA, M. S.; MORALES-RAMÍREZ, J. O.; CARRASQUILLA, G.; REY, L. C.; DIETZE, R.; LUZ, K.; RIVAS, E.; MIRANDA MONTOYA, M. C.; CORTÉS SUPELANO, M.; ZAMBRANO, B.; LANGEVIN, E.; BOAZ, M.; TORNIEPORTH, N.; SAVILLE, M.; NORIEGA, F. Efficacy of a tetravalent dengue vaccine in children in Latin America. The New England Journal Of Medicine, v. 372, p. 113-23, 2015.

WANG, S.; JACOBS-LORENA, M. Genetic approaches to interfere with malaria transmission by vector mosquitoes. Trends In Biotechnology, v. 31, p. 185-93, 2013.

WANG, W.; LIU, S.-L. L.; LIU, Y.-Y. Y.; QIAO, C.-L. L.; CHEN, S.-L. L.; CUI, F. Overtranscription of genes in a parathion-resistant strain of mosquito Culex pipiens quinquefasciatus. Insect Science, v. 22, p. 150-6, 2014. 
WANG, Z.; LI, S.; SUN, L.; FAN, J.; LIU, Z. Comparative Analyses of Lipoprotein Lipase, Hepatic Lipase, and Endothelial Lipase, and Their Binding Properties with Known Inhibitors, Plos One, v. 8, n. 8, e72146, 2013.

WEAVER, S. C. Arrival of chikungunya virus in the new world: prospects for spread and impact on public health. PLoS Negleted Tropical Disease, v. 8, e2921, 2014.

WEAVER, S. C.; FORRESTER, N. L. Chikungunya: Evolutionary history and recent epidemic spread. Antiviral Research, v. 120, p. 32-39, 2015.

WEIDLICH, S.; HOFFMANN, K. H.; WOODRING, J. SECRETION OF LIPASES IN THE DIGESTIVE TRACT OF THE CRICKET Gryllus bimaculatus. Archives Of Insect Biochemistry And Physiology, v. 90, n. 4, p. 209-217, 2015.

WEINTRAUB, H.; TIETZ, A. Triglyceride digestion and absorption in the locust, Locusta migratoria. Biochimica Et Biophysica Acta, v. 306, p. 31-41, 1973.

WORLD HEALTH ORGANIZATION. Emergencies: Yellow Fever.. Disponível em: http://www.who.int/emergencies/yellow-fever/mediacentre/qa/en/> Acesso em: 06 set. 2016a.

WORLD HEALTH ORGANIZATION. Media Centre: Dengue and severe dengue. Disponível em: <http://www.who.int/mediacentre/factsheets/fs117/en/> Acesso em: 10 out. $2016 \mathrm{~b}$.

WORLD HEALTH ORGANIZATION. Programmes and Projects: Malaria. Disponível em: <http://www.who.int/malaria/en/ > Acesso em: 25 jun. 2016c.

WORLD HEALTH ORGANIZATION. Media Centre: Malaria. Disponível em: < http://www.who.int/mediacentre/factsheets/fs094/en/> Acesso em: 14 mai. 2016d.

WORLD HEALTH ORGANIZATION. Media Centre: WHO welcomes global health funding for malaria vaccine. Disponível em: < http://www.who.int/mediacentre/news/releases/2016/funding-malaria-vaccine/en/> Acesso em: 20 nov. 2016e.

WINKLER, F. K.; D'ARCY, A.; HUNZIKER, W. Structure of human pancreatic lipase. Nature, v. 343, p. 771-774, 1990.

WONG, H.; AND SCHOTZ, M. C. The lipase gene family. Journal Of Lipid Research, v. 43, p. 993-9, 2002.

WOOD, J. D.; ENSER, M.; FISHER, A. V.; NUTE, G. R.; SHEARD, P. R.; RICHARDSON, R. I.; HUGHES, S. I.; WHITTINGTON, F. M. Fat deposition, fatty acid composition and meat quality: A review. Meat Science, v. 78, n. 4, p. 343-58, 2008.

WOODALL, J. P.; YUILL, T. M. Why is the yellow fever outbreak in Angola a "threat to the entire world"?. International Journal Of Infectious Diseases, v. 48, p. 96-7, 2016. 
XIE, Y.; AN, J.; YANG, G.; WU, G.; ZHANG, Y.; CUI, L.; FENG, Y. Enhanced enzyme kinetic stability by increasing rigidity within the active site. The Journal Of Biological Chemistry, v. 289, p. 7994-8006, 2014.

XU, K.; LI, F.; MA, L.; WANG, B.; ZHANG, H.; NI, M.; HONG, F.; SHEN, W.; LI, B. Mechanism of enhanced Bombyx mori nucleopolyhedrovirus-resistance by titanium dioxide nanoparticles in silkworm. PLoS ONE, v. 10, 2015. e0118222.

YIN, C.; SHEN, G.; GUO, D.; WANG, S.; MA, X.; XIAO, H.; LIU, J.; ZHANG, Z.; LIU, Y.; ZHANG, Y.; YU, K.; HUANG, S.; LI, F. InsectBase: a resource for insect genomes and transcriptomes. Nucleic Acids Research, v. 44, p. D801-807, 2016.

YU, X.; SUN, Q.; LI, B.; XIE, Y.; ZHAO, X.; HONG, J.; SHENG, L.; SANG, X.; GUI, S.; WANG, L.; SHEN, W.; HONG, F. Mechanisms of larval midgut damage following exposure to phoxim and repair of phoxim-induced damage by cerium in Bombyx mori. Environmental Toxicology, v. 30, p. 452-460, 2015.

ZANLUCA, C.; MELO, V. C.; MOSIMANN, A. L.; SANTOS, G. I.; SANTOS, C. N.; LUZ, K. First report of autochthonous transmission of Zika virus in Brazil. Memórias Do Instituto Oswaldo Cruz, v. 110, p. 569-72, 2015.

ZIBAEE, A. A digestive lipase of Pieris brassicae L. (Lepidoptera: Pieridae): purification, characterization, and host plants effects. Archives Of Insect Biochemistry Physiology, v. 81, p. 1-19, 2012.

ZINKE, I.; SCHÜTZ, C. S.; KATZENBERGER, J. D.; BAUER, M.; PANKRATZ, M. J. Nutrient control of gene expression in Drosophila: microarray analysis of starvation and sugar-dependent response. EMBO Journal, v. 21, p. 6162-73, 2002.

ZOUARI, N.; MILED, N.; CHERIF, S.; MEJDOUB, H.; GARGOURI, Y. Purification and characterization of a novel lipase from the digestive glands of a primitive animal: Biochimie, v. 89, p. 403-409, 2007.

ZOUARI, N.; MILED, N.; ROUIS, S.; GARGOURI, Y. Scorpion digestive lipase: A member of a new invertebrate's lipase group presenting novel characteristics. The scorpion. Biochimica Et Biophysica Acta, v. 1726, p. 67-74, 2005. 